Cochrane Database of Systematic Reviews

\title{
Single dose oral diclofenac for acute postoperative pain in adults
} (Review)

Derry S, Wiffen PJ, Moore RA

Derry S, Wiffen PJ, Moore RA.

Single dose oral diclofenac for acute postoperative pain in adults.

Cochrane Database of Systematic Reviews 2015, Issue 7. Art. No.: CD004768.

DOI: 10.1002/14651858.CD004768.pub3.

www.cochranelibrary.com 
TABLE OF CONTENTS

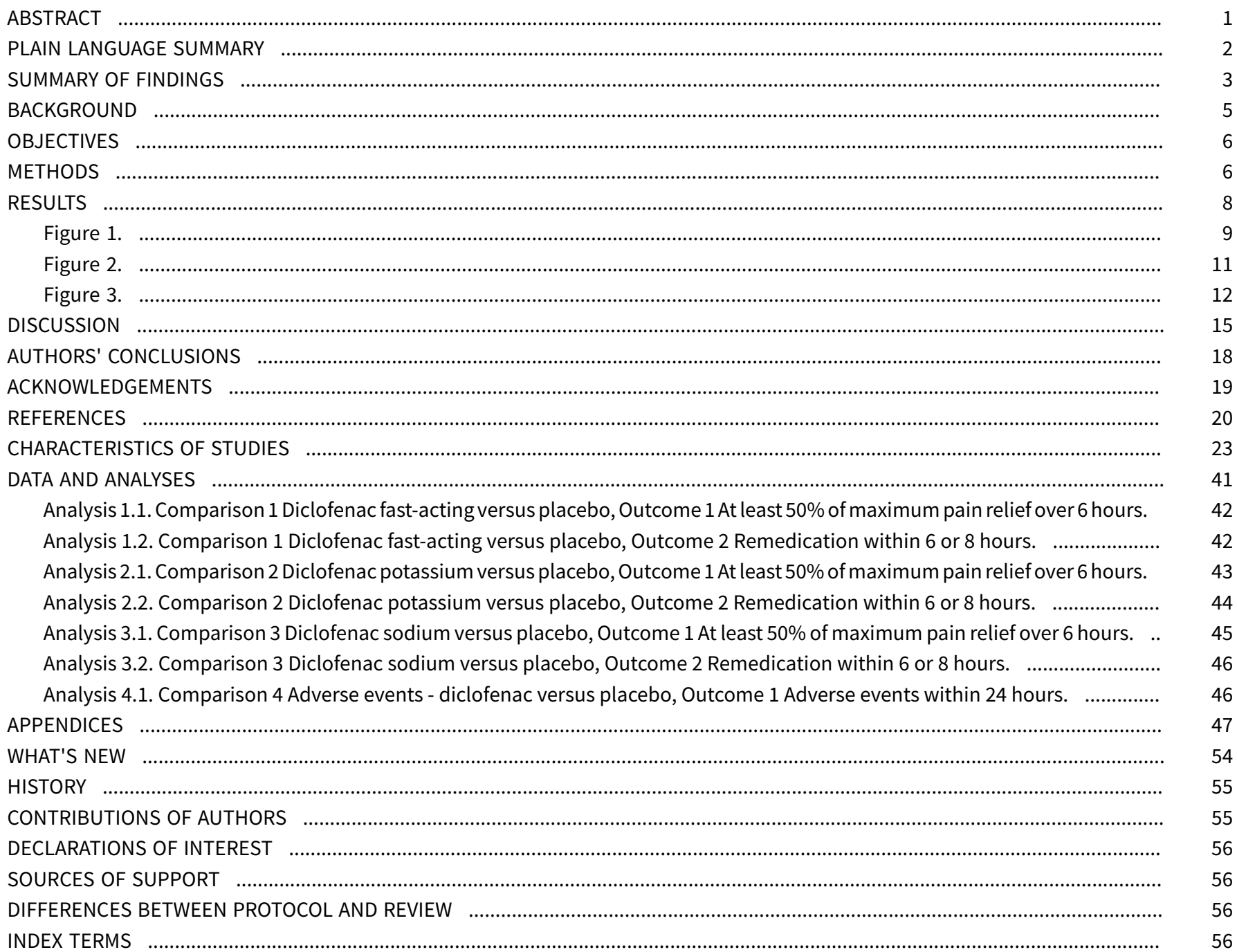


[Intervention Review]

\section{Single dose oral diclofenac for acute postoperative pain in adults}

Sheena Derry ${ }^{1}$, Philip J Wiffen², R Andrew Moore ${ }^{3}$

1Oxford, UK. ${ }^{2}$ Thame, UK. ${ }^{3}$ Plymouth, UK

Contact: Sheena Derry, Oxford, Oxfordshire, UK. sheena.derry@retired.ox.ac.uk.

Editorial group: Cochrane Pain, Palliative and Supportive Care Group.

Publication status and date: Stable (no update expected for reasons given in 'What's new'), published in Issue 5, 2019.

Citation: Derry S, Wiffen PJ, Moore RA. Single dose oral diclofenac for acute postoperative pain in adults. Cochrane Database of Systematic Reviews 2015, Issue 7. Art. No.: CD004768. DOI: 10.1002/14651858.CD004768.pub3.

Copyright $\odot 2019$ The Cochrane Collaboration. Published by John Wiley \& Sons, Ltd.

\section{A B S T R A C T}

\section{Background}

Diclofenac is a nonsteroidal anti-inflammatory drug, available as a potassium salt (immediate release) or sodium salt (enteric coated to suppress dissolution in the stomach). This review updates an earlier review published in the Cochrane Database of Systematic Reviews (Issue 2, 2009) entitled 'Single dose oral diclofenac for acute postoperative pain in adults'.

\section{Objectives}

To assess the analgesic efficacy and adverse effects of a single oral dose of diclofenac for moderate to severe postoperative pain, using methods that permit comparison with other analgesics evaluated in standardised trials using almost identical methods and outcomes.

\section{Search methods}

We searched the Cochrane Central Register of Controlled Trials (CENTRAL), MEDLINE, EMBASE, the Oxford Pain Relief Database, two clinical trial registries, and the reference lists of articles. The date of the most recent search was 9 March 2015.

\section{Selection criteria}

Randomised, double-blind, placebo-controlled clinical trials of single dose, oral diclofenac (sodium or potassium) for acute postoperative pain in adults.

\section{Data collection and analysis}

Two review authors independently considered studies for inclusion in the review, assessed risk of bias, and extracted data. We used the area under the pain relief versus time curve to derive the proportion of participants with at least $50 \%$ pain relief over six hours prescribed either diclofenac or placebo. We calculated the risk ratio (RR) and number needed to treat to benefit (NNT). We used information on the use of rescue medication to calculate the proportion of participants requiring rescue medication and the weighted mean of the median time to use. We also collected information on adverse effects.

\section{Main results}

This update included three new studies, providing a $26 \%$ increase in participants in comparisons between diclofenac and placebo. We included 18 studies involving 3714 participants, 1902 treated with diclofenac and 1007 with placebo. This update has also changed the focus of the review, examining the effects of formulation in more detail than previously. This is a result of increased understanding of the importance of speed of onset in determining analgesic efficacy in acute pain.

The largest body of information, for diclofenac potassium $50 \mathrm{mg}$, in seven studies, produced an NNT for at least $50 \%$ of maximum pain relief compared with placebo of 2.1 (95\% confidence interval (CI) 1.9 to 2.5 ) (high quality evidence). There was a graded improvement in efficacy as doses rose from $25 \mathrm{mg}$ to $100 \mathrm{mg}$, both for participants achieving at least $50 \%$ maximum pain relief, and for remedication within 6 to 8 hours. Fast-acting formulations (dispersible products, solutions, and softgel formulations) had a similar efficacy for a 50 mg dose, 
with an NNT of 2.4 (2.0 to 3.0). Diclofenac sodium in a small number of studies produced a lesser effect, with an NNT of 6.6 (4.1 to 17 ) for the $50 \mathrm{mg}$ dose.

Adverse event rates were low in these single dose studies, with no difference between diclofenac and placebo (moderate quality evidence).

\section{Authors' conclusions}

Diclofenac potassium provides good pain relief at $25 \mathrm{mg}, 50 \mathrm{mg}$, and $100 \mathrm{mg}$ doses. Diclofenac sodium has limited efficacy and should probably not be used in acute pain.

\section{PLAIN LANGUAGE SUMMARY}

\section{Single dose oral diclofenac for acute postoperative pain in adults}

Acute pain is often felt soon after injury. Most people who have surgery have moderate or severe pain afterwards. Painkillers are tested in people with pain, often following a painful condition such as the removal of wisdom teeth. This pain is usually treated with painkillers taken by mouth. We believe these results can be applied to other acute painful conditions.

A series of Cochrane reviews looks at how good painkillers are. We know that in some circumstances, fast-dissolving and absorbed painkillers provide better pain relief than those that are absorbed slowly. This review examined how good different formulations of diclofenac were in relieving moderate or severe pain after surgery.

This is an update of a review published in 2009. New searches in March 2015 identified three new studies, making 18 studies with 3714 participants altogether, 1902 of whom were treated with diclofenac and 1007 with placebo. Diclofenac potassium is a rapidly absorbed formulation, and the $50 \mathrm{mg}$ dose provided the largest amount on information. With this dose of this formulation, more than 6 in 10 (64\%) participants had effective pain relief, compared with fewer than 2 in $10(17 \%)$ with placebo (high quality evidence).

Adverse events occurred at similar rates with diclofenac and placebo in these single dose studies (moderate quality evidence). There were few serious adverse events or withdrawals due to adverse events.

Diclofenac potassium represents a useful option in controlling acute pain. 
SUMMARY OF FINDINGS

Summary of findings for the main comparison.

Diclofenac potassium compared with placebo for moderate to severe acute pain in adults

Patient or population: Adults with acute pain

Settings: Hospital or community

Intervention: Oral diclofenac potassium $50 \mathrm{mg}$

Comparison: Oral placebo

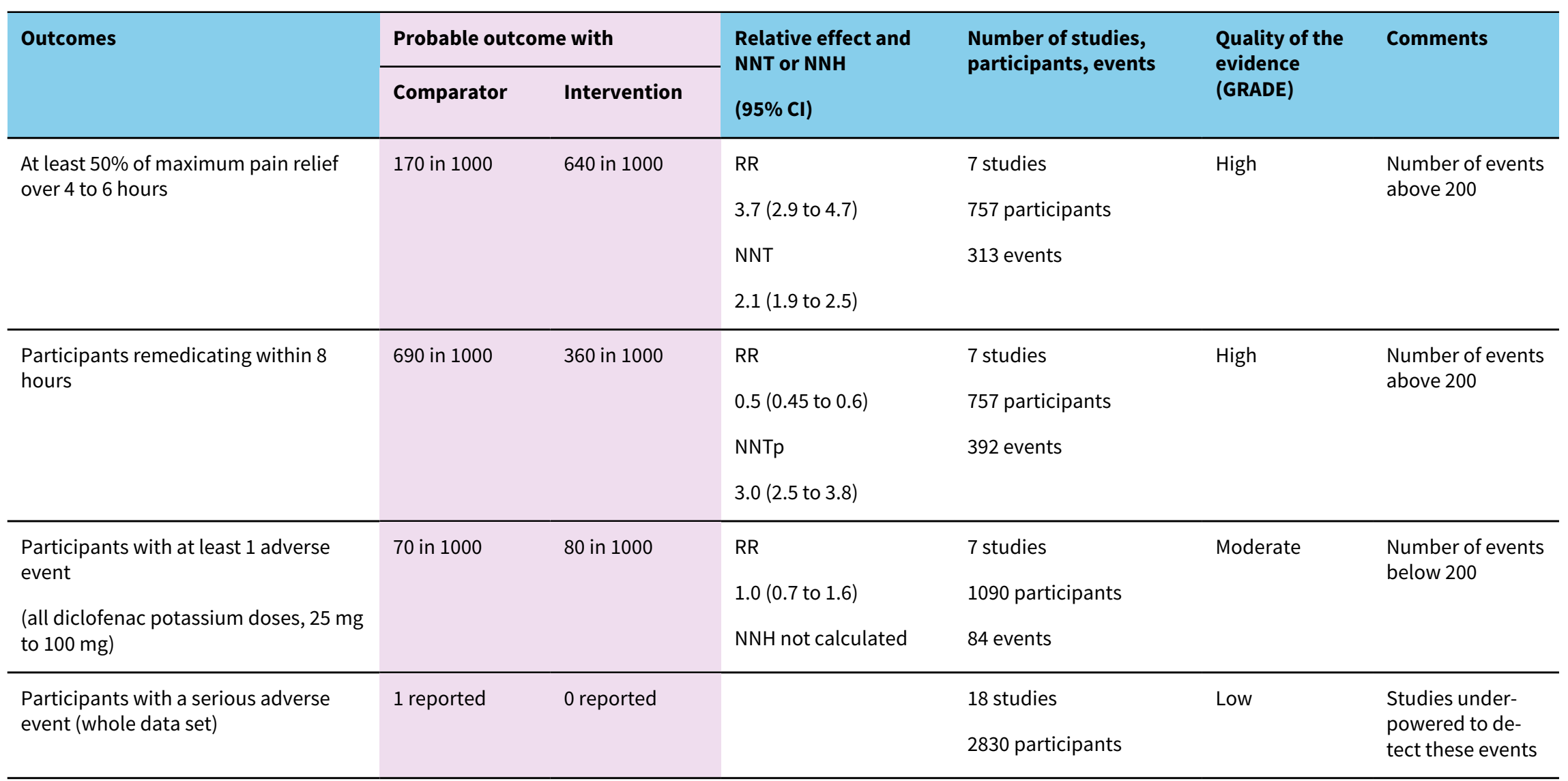

GRADE Working Group grades of evidence

High quality: Further research is very unlikely to change our confidence in the estimate of effect. 
Moderate quality: Further research is likely to have an important impact on our confidence in the estimate of effect and may change the estimate.

Low quality: Further research is very likely to have an important impact on our confidence in the estimate of effect and is likely to change the estimate.

Very low quality: We are very uncertain about the estimate.

$\mathrm{Cl}$ : confidence interval; NNT: number needed to treat to benefit; NNH: number needed to treat to harm or cause one event; NNTp: number needed to treat to prevent one event; RR: risk ratio 


\section{B A C K G R O U N D}

This review updates an earlier review published in the Cochrane Database of Systematic Reviews (Issue 2, 2009) entitled 'Single dose oral diclofenac for acute postoperative pain in adults' (Derry 2009a). We carried out additional searches in 2011 that identified no new studies, and therefore planned a full update for 2015.

This is one of a series of reviews whose aim is to increase awareness of the range of analgesics that are potentially available, and to present evidence for relative analgesic efficacy through indirect comparisons with placebo, in very similar trials performed in a standard manner, with very similar outcomes, and over the same duration. Such relative analgesic efficacy does not in itself determine choice of drug for any situation or patient, but guides policy making at the local level. The series covers all analgesics licensed for acute postoperative pain in Europe and North America, and dipyrone, which is commonly used in Spain, Portugal, and Latin American countries. The results have been examined in an overview (Moore 2011a), and important individual reviews include ibuprofen (Derry 2009b), codeine (Derry 2010), paracetamol (Toms 2008), and etoricoxib (Clarke 2012), and combinations of ibuprofen with paracetamol (Derry 2013a), codeine (Derry 2013b), and oxycodone (Derry 2013c). Knowing the relative efficacy of different analgesic drugs at various doses can be helpful.

\section{Description of the condition}

Acute pain occurs as a result of tissue damage either accidentally due to an injury or as a result of surgery. Acute postoperative pain is a manifestation of inflammation due to tissue injury or nerve injury, or both. The management of postoperative pain and inflammation is a critical component of patient care.

\section{Description of the intervention}

\section{Acute pain trials}

Single dose trials in acute pain are commonly short in duration, rarely lasting longer than 12 hours. The numbers of participants are small, allowing no reliable conclusions to be drawn about safety. To show that the analgesic is working, it is necessary to use placebo (McQuay 2005). There are clear ethical considerations in doing this. These ethical considerations are answered by using acute pain situations where the pain is expected to go away, and by providing additional analgesia, commonly called rescue analgesia, if the pain has not diminished after about an hour. This is reasonable, because not all participants given an analgesic will have significant pain relief. Approximately $18 \%$ of participants given placebo will have significant pain relief (Moore 2006), and up to $50 \%$ may have inadequate analgesia with active medicines. The use of additional or rescue analgesia is hence important for all participants in the trials.

Clinical trials measuring the efficacy of analgesics in acute pain have been standardised over many years (McQuay 2012). Trials have to be randomised and double-blind. Typically, in the first few hours or days after an operation, patients develop pain that is moderate to severe in intensity, and will then be given the test analgesic or placebo. Pain is measured using standard pain intensity scales immediately before the intervention, and then using pain intensity and pain relief scales over the following 4 to 6 hours for shorter-acting drugs, and up to 12 or 24 hours for longer-acting drugs. Pain relief of half the maximum possible pain relief or better (at least 50\% pain relief) is typically regarded as a clinically useful outcome. For patients given rescue medication, it is usual for no additional pain measurements to be made, and for all subsequent measures to be recorded as initial pain intensity or baseline (zero) pain relief (baseline observation carried forward). This process ensures that analgesia from the rescue medication is not wrongly ascribed to the test intervention. In some trials the last observation is carried forward, which gives an inflated response for the test intervention compared to placebo, but the effect has been shown to be negligible over four to six hours (Moore 2005). Patients usually remain in the hospital or clinic for at least the first six hours following the intervention, with measurements supervised, although they may then be allowed home to make their own measurements in trials of longer duration.

\section{Diclofenac}

Diclofenac is a benzene acetic acid derivative used to treat the pain and swelling associated with rheumatic disorders since 1974 (Fineschi 1997). It is one of the most widely used nonsteroidal antiinflammatory drugs (NSAIDs) in the world, especially outside the USA. The most common daily doses are $75 \mathrm{mg}$ and $150 \mathrm{mg}$, given as divided doses.

Diclofenac is available in two different salts in a number of different formulations. Diclofenac sodium is usually distributed in enteric-coated tablets, which resist dissolution in low $\mathrm{pH}$ gastric environments and release contents in the duodenum (Olson 1997); this tends to produce slow absorption into blood. Diclofenac potassium is formulated to be released and absorbed in the stomach, and references to pharmaceutical company data indicate that peak plasma concentrations occur by about 45 minutes (Bakshi 1992). Fast-acting formulations may involve diclofenac sodium or potassium, but are designed to dissolve diclofenac in the stomach contents and promote rapid uptake, with peak plasma concentrations at 30 minutes or so. We could not find a systematic review of diclofenac absorption kinetics with these different formulations.

Of the two salts, diclofenac potassium and diclofenac sodium, the sodium salt is used much more frequently ( $98 \%$ of the 2.3 million prescriptions in England in 2013 were of the sodium salt; PCA 2014). Diclofenac potassium is the formulation usually available at lower doses without prescription.

Fast-acting formulations not only produce more rapid plasma concentrations and pain relief, but better overall results and a longer duration of action, at least for ibuprofen (Moore 2014; Moore 2015a). There is no similar comprehensive review of effects of formulation for diclofenac, but the evidence is now strong that fast-acting formulations are likely to have different effects from standard formulations. Taking drugs with food reduces and delays absorption of NSAIDs, including diclofenac, and may impair analgesic efficacy (Moore 2015b). Where drugs are taken for a short time, adverse events in single dose studies are not generally different from placebo (Moore 2011a).

Diclofenac potassium formulations were recently withdrawn from non-prescription sale in the UK due to concerns over potential cardiovascular risk. 


\section{How the intervention might work}

Clinicians prescribe NSAIDs on a routine basis for a range of mild to moderate pain. NSAIDs are the most commonly prescribed analgesic medications worldwide, and their efficacy for treating acute pain has been well demonstrated (Moore 2003). They reversibly inhibit cyclooxygenase (prostaglandin endoperoxide synthase), the enzyme mediating production of prostaglandins and thromboxane A2 (FitzGerald 2001). Prostaglandins mediate a variety of physiological functions such as maintenance of the gastric mucosal barrier, regulation of renal blood flow, and regulation of endothelial tone. They also play an important role in inflammatory and nociceptive processes. However, relatively little is known about the mechanism of action of this class of compounds aside from their ability to inhibit cyclooxygenasedependent prostanoid formation (Hawkey 1999). Since NSAIDs do not depress respiration and do not impair gastrointestinal motility as opioids do, they are clinically useful for treating pain after minor surgery and day surgery, and have an opioid-sparing effect after more major surgery (Grahame-Smith 2002).

A major concern regarding the use of conventional NSAIDs postoperatively is the possibility of bleeding from both the operative site (because of the inhibition of platelet aggregation) (Forrest 2002), and from the upper gastrointestinal tract (especially in patients stressed by surgery, the elderly, frail, or dehydrated). Other potentially serious adverse events include acute liver injury, acute renal injury, heart failure, and adverse reproductive outcomes (Hernández-Díaz 2001). Research has also implicated diclofenac in haematological abnormalities (Martindale 2015). However, such complications are more likely to occur with chronic use, and NSAIDs generally present fewer risks with short term use, as in the treatment of postoperative pain (Rapoport 1999).

\section{Why it is important to do this review}

The original version of this review included both ibuprofen and diclofenac, and was an update of a previous non-Cochrane review (Collins 1998). A 2004 update of diclofenac included only included seven studies in which 581 participants were treated with diclofenac and 364 with placebo (Barden 2004). A further updated review included 15 studies, with 1512 participants treated with diclofenac and 793 with placebo (Derry 2009a).

Since 2011, new clinical trials have been published, and the importance of formulation has been recognised. Taken together these factors meant that results of the previous reviews needed to be revisited.

\section{O B JECTIVES}

To assess the analgesic efficacy and adverse effects of a single oral dose of diclofenac for moderate to severe postoperative pain, using methods that permit comparison with other analgesics evaluated in standardised trials using almost identical methods and outcomes.

\section{METHODS}

\section{Criteria for considering studies for this review}

\section{Types of studies}

We included double-blind studies of single dose oral diclofenac compared with placebo for the treatment of moderate to severe postoperative pain in adults, with at least 10 participants randomly allocated to each treatment group. We included multiple dose studies if appropriate data from the first dose were available, and cross-over studies provided that data from the first arm were presented separately.

We excluded:

- review articles, case reports, and clinical observations;

- studies of experimental pain;

- studies where pain relief was assessed only by clinicians, nurses, or carers (not participant-reported);

- studies of less than four hours' duration or studies that failed to present data over four to six hours postdose.

For postpartum pain, we included studies if the pain investigated was due to episiotomy or Caesarean section irrespective of the presence of uterine cramps; we excluded studies investigating pain due to uterine cramps alone.

\section{Types of participants}

We included studies of adult participants (15 years or older) with established postoperative pain of moderate to severe intensity following day surgery or in-patient surgery. For studies using a visual analogue scale (VAS), we considered that pain intensity of greater than $30 \mathrm{~mm}$ equated to pain of at least moderate intensity (Collins 1997).

\section{Types of interventions}

Orally administered diclofenac sodium or potassium with matched placebo administered as a single oral dose for postoperative pain.

\section{Types of outcome measures}

We collected the following data where available.

- Participant characteristics.

- Participant-reported pain at baseline (we did not include physician-, nurse-, or carer-reported pain in the analysis).

- Participant-reported pain relief expressed at least hourly over four to six hours using validated pain scales (pain intensity or pain relief in the form of VAS or categorical scales, or both).

- Patient global assessment of efficacy (PGE), using a standard categorical scale.

- Time to use of rescue medication.

- Number of participants using rescue medication.

- Number of participants with one or more adverse events.

- Number of participants with serious adverse events.

- Number of withdrawals (all-cause, adverse events).

\section{Primary outcomes}

Participants achieving at least 50\% pain relief over four to six hours (Moore 2011b).

\section{Secondary outcomes}

1. Median (or mean) time to use of rescue medication.

2. Participants using rescue medication.

3. Participants with: any adverse event; any serious adverse event (as reported in the study); withdrawal due to an adverse event. 
4. Other withdrawals: withdrawals for reasons other than lack of efficacy (participants using rescue medication).

\section{Search methods for identification of studies}

\section{Electronic searches}

We searched the following databases.

- Cochrane Central Register of Controlled Trials (CENTRAL), the Cochrane Library Issue 4, 2008 for the earlier version, and via Cochrane Register of Studies Online (CRSO) to 9 March 2015 for this update.

- MEDLINE (via Ovid) from inception to December 2008 for the earlier versions, and 2008 to 9 March 2015 for this update.

- EMBASE (via Ovid) from inception to December 2008 for the earlier versions, and 2008 to 9 March 2015 for this update.

- The Oxford Pain Relief Database (Jadad 1996a) for the earlier version. This database is no longer being updated.

See Appendix 1 for the CENTRAL search strategy, Appendix 2 for the MEDLINE search strategy, and Appendix 3 for the EMBASE search strategy.

\section{Searching other resources}

We searched for additional studies in reference lists of retrieved articles and reviews. We also searched the ClinicalTrials database (www.clinicaltrials.gov) and the WHO International Clinical Trials Registry Platform (apps.who.int/trialsearch/) for otherwise unpublished trial results and information about ongoing studies.

Merck provided details of two unpublished studies for the original review, but we did not contact manufacturers for this update.

\section{Data collection and analysis}

\section{Selection of studies}

Two review authors independently assessed the search results and agreed on the studies to be included in the review. Disagreements would have been resolved by consensus or referral to a third review author, but this was not necessary.

\section{Data extraction and management}

Two review authors extracted data and recorded them on a standard data extraction form. One review author entered data suitable for pooling into RevMan 5.3 (RevMan 2014).

\section{Assessment of risk of bias in included studies}

We used the Oxford Quality Score as the basis for study inclusion, limiting inclusion to studies that were randomised and doubleblind as a minimum (Jadad 1996b).

We also completed a 'Risk of bias' table using methods adapted from those described by the Cochrane Pregnancy and Childbirth Group. Two review authors independently assessed risk of bias for each study using the criteria outlined in the Cochrane Handbook for Systematic Reviews of Interventions, resolving any disagreements by discussion (Higgins 2011). We assessed the following for each study.

1. Random sequence generation (checking for possible selection bias). We assessed the method used to generate the allocation sequence as: low risk of bias (any truly random process: random number table; computer random number generator); unclear risk of bias (method used to generate sequence not clearly stated). We excluded studies using a non-random process (odd or even date of birth; hospital or clinic record number), which were therefore at high risk of bias.

2. Allocation concealment (checking for possible selection bias). The method used to conceal allocation to interventions before assignment determines whether the intervention allocation could have been foreseen in advance of, or during recruitment, or changed after assignment. We assessed the methods as: low risk of bias (telephone or central randomisation; consecutively numbered, sealed, opaque envelopes); unclear risk of bias (method not clearly stated). We excluded studies that did not conceal allocation (open list), which were therefore at high risk of bias.

3. Blinding of outcome assessment (checking for possible detection bias). We assessed the methods used to blind study participants and outcome assessors from knowledge of which intervention a participant received. We assessed the methods as: low risk of bias (study stated that it was blinded and described the method used to achieve blinding: identical tablets; matched in appearance and smell); unclear risk of bias (study stated that it was blinded but did not provide an adequate description of how blinding was achieved). We excluded studies that were not double-blind and therefore at high risk of bias.

4. Size (checking for possible biases confounded by small size). Small studies have been shown to overestimate treatment effects, probably because the conduct of small studies is more likely to be less rigorous, allowing critical criteria to be compromised (Dechartres 2013; Nüesch 2010). We considered studies to be at low risk of bias if they had 200 participants or more, at unclear risk if they had 50 to 200 participants, and at high risk of bias if they had fewer than 50 participants.

\section{Measures of treatment effect}

We used risk ratio (or relative risk, RR) to establish statistical difference, and numbers needed to treat to benefit (NNT) and pooled percentages as absolute measures of benefit or harm.

We used the following terms to describe adverse outcomes in terms of harm or prevention of harm.

- When significantly fewer adverse outcomes occurred with treatment than with control (placebo or active), we used the term the number needed to treat to prevent one event (NNTp).

- When significantly more adverse outcomes occurred with treatment compared with control (placebo or active), we used the term the number needed to treat to harm or cause one event (NNH).

\section{Unit of analysis issues}

We accepted only randomisation of the individual participant.

\section{Dealing with missing data}

The only likely issue with missing data in these studies was from imputation using last observation carried forward when a patient requested rescue medication. We have previously shown that this does not affect results for up to six hours after taking study medication (Moore 2005). 


\section{Assessment of heterogeneity}

We examined heterogeneity using L'Abbé plots (L'Abbé 1987), a visual method for assessing differences in results of individual studies.

\section{Assessment of reporting biases}

We assessed the number of trials of average size amongst the included studies, with a RR of 1 (no effect), that would be needed to reduce any statistically significant result to one that fails to meet statistical significance (following Moore 2008).

\section{Data synthesis}

For efficacy analyses we used the number of participants in each treatment group who were randomised, received medication, and provided at least one post-baseline assessment. For safety analyses we used the number of participants randomised to each treatment group who took the study medication. We analysed results for different doses separately.

For each study we converted the mean total pain relief (TOTPAR), summed pain intensity difference (SPID), VAS TOTPAR, or VAS SPID values for the active and placebo groups to \%maxTOTPAR or \%maxSPID by division into the calculated maximum value (see Appendix 4; Cooper 1991). We then calculated the proportion of participants in each treatment group who achieved at least 50\%maxTOTPAR using verified equations (Moore 1997a; Moore 1997b; Moore 1997b). We converted these proportions into the number of participants achieving at least 50\%maxTOTPAR by multiplying by the total number of participants in the treatment group. We used this information on the number of participants with at least 50\%maxTOTPAR for active and placebo groups to calculate RR and NNT.

We accepted the following pain measures for the calculation of TOTPAR or SPID (in order of priority; see Appendix 4).

- Five-point categorical pain relief scales with comparable wording to 'none, slight, moderate, good, or complete'.

- Four-point categorical pain intensity scales with comparable wording to 'none, mild, moderate, severe'.

- VAS for pain relief.

- VAS for pain intensity.

If none of these measures was available, we used the number of participants reporting 'very good or excellent' on a five-point categorical global scale with the wording 'poor, fair, good, very good, excellent' for the number of participants achieving at least $50 \%$ pain relief (Collins 2001).
For each treatment group we extracted the number of participants reporting treatment-emergent adverse effects and calculated relative benefit and risk estimates with $95 \%$ confidence intervals (Cl) using a fixed-effect model (Morris 1995). We calculated NNT and $\mathrm{NNH}$ with $95 \% \mathrm{Cls}$ from the pooled number of events using the method of Cook and Sackett (Cook 1995). We assumed a statistically significant difference from control when the $95 \% \mathrm{Cl}$ of the RR did not include the number one.

\section{Subgroup analysis and investigation of heterogeneity}

We planned to report results according to formulation, and within a formulation the dose of diclofenac. The three formulations used were:

1. any fast-acting formulation (gel capsule, effervescent or other solution, or other formulation declared to be fast-acting). Both salts were allowed for this analysis;

2. diclofenac potassium; and

3. diclofenac sodium.

In this update, we include any formulation tested.

A minimum of two studies and 200 participants had to be available in any subgroup analysis (Moore 1998), which was restricted to the primary outcome (50\% pain relief over 4 to 6 hours) and the dose with the greatest amount of data. We determined significant differences between NNT, NNTp, or NNH for different groups in subgroup and sensitivity analyses using the $z$ test (Tramèr 1997).

\section{Sensitivity analysis}

No sensitivity analyses were planned.

\section{RES U L T S}

\section{Description of studies}

\section{Results of the search}

The 2009 review included 15 studies (Ahlstrom 1993; Bakshi 1992; Bakshi 1994; Chang 2002; Cooper 1996; Desjardins 2004; Herbertson 1995; Hersh 2004; Hofele 2006; Kubitzek 2003; Mehlisch 1995; Nelson 1994; Olson 1997; Torres 2004; Zuniga 2004). Searches run for this update identified six other candidate publications (Daniels 2012; Manvelian 2012a; NCT01462435; Riff 2009; Zuniga 2010; Zuniga 2011).

One of these is an ongoing study (NCT01462435); details are in the Characteristics of studies awaiting classification table. Two others were pooled analyses of various outcomes from two randomised trials already included (Daniels 2012; Zuniga 2011).

Figure 1 shows the results of the searches. 
Figure 1. Study flow diagram.

15 studies included in previous version of review

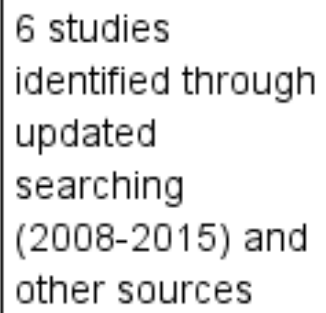

6 studies

identified through

updated

searching

(2008-2015) and

other sources

2 studies

excluded because

they were pooled

analyses of

studies that were

already included,

but with outcomes

not relevant to

this review

1 ongoing study

18 studies

included in

qualitative

synthesis

3 new studies included 


\section{Included studies}

The 18 included studies enrolled 3714 participants. Treatments tested are shown in Table A. Active comparators included aspirin, ibuprofen, rofecoxib, and valdecoxib, but there were no more than two studies for any one.

Table A: Treatments tested

\begin{tabular}{lll}
\hline Drug & Diclofenac dose $\mathbf{( m g})$ & Number treated \\
\hline Fast-acting diclofenac & 25 & 254 \\
& 50 & 92 \\
\hline Diclofenac K & 100 & 248 \\
& 25 & 395 \\
\hline Diclofenac Na & 50 & 302 \\
\hline Piclofenac nanoparticles & 100 & 193 \\
\hline Active comparators & 50 & 68 \\
\hline
\end{tabular}

Thirteen studies were in participants with dental pain following surgical extraction of one or more impacted third molars (Ahlstrom 1993; Bakshi 1992; Bakshi 1994; Chang 2002; Cooper 1996; Hersh 2004; Hofele 2006; Kubitzek 2003; Manvelian 2012a; Mehlisch 1995; Nelson 1994; Zuniga 2004; Zuniga 2010). Two studies involved pain following bunionectomy (Desjardins 2004; Riff 2009). Others involved general gynaecological surgery (Herbertson 1995), postepisiotomy pain (Olson 1997), and inguinal hernia (Torres 2004). Details of the included studies are in Characteristics of included studies.

\section{Excluded studies}

Details of excluded studies are in Characteristics of excluded studies.

\section{Risk of bias in included studies}

All included studies were both randomised and double-blind. On the Oxford Quality Scale, we gave five studies a quality score of five (Chang 2002; Desjardins 2004; Hersh 2004; Hofele 2006; Zuniga 2004), eight a score of four (Ahlstrom 1993; Bakshi 1994; Kubitzek 2003; Nelson 1994; Mehlisch 1995; Olson 1997; Riff 2009; Zuniga 2010), and five a score of three (Bakshi 1992; Cooper 1996; Herbertson 1995; Manvelian 2012a; Torres 2004).

\section{Allocation}

All studies reported that they were randomised, and six adequately described the method used to generate the random sequence. The method used to conceal the random allocation was not generally described. For one study, allocation concealment was suspected possibly not to be adequate (Zuniga 2004) (Figure 2 and Figure 3). 
Figure 2. Risk of bias graph: review authors' judgements about each risk of bias item presented as percentages across all included studies.

Random sequence generation (selection bias)

Allocation concealment (selection bias)

Blinding of participants and personnel (performance bias)

Size

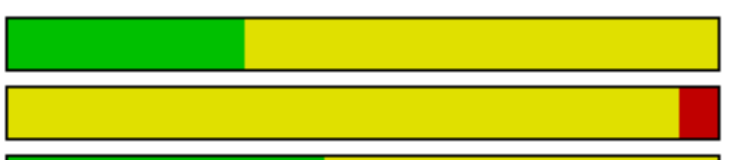

L

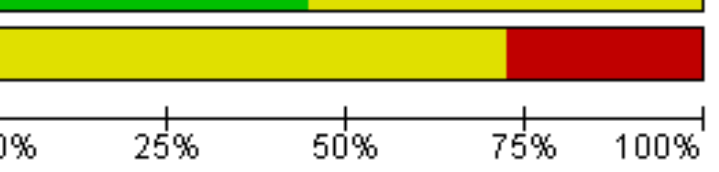

$\begin{array}{lllll}0 \% & 25 \% & 50 \% & 75 \% & 100 \%\end{array}$

Low risk of bias

Unclear risk of bias

High risk of bias 
Figure 3. Risk of bias summary: review authors' judgements about each risk of bias item for each included study.

\begin{tabular}{|c|c|c|c|c|}
\hline & 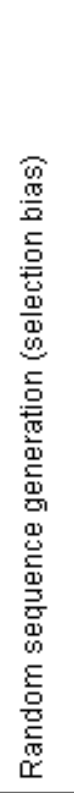 & 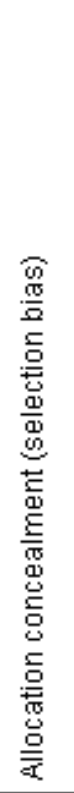 & 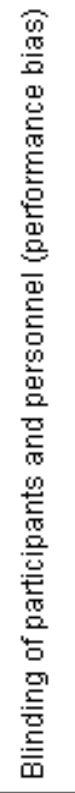 & 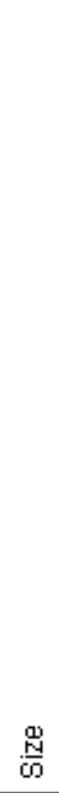 \\
\hline Ahlstrom 1993 & $?$ & $?$ & + & - \\
\hline Bakshi 1992 & $?$ & $?$ & $?$ & - \\
\hline Bakshi 1994 & $?$ & $?$ & + & $?$ \\
\hline Chang 2002 & + & $?$ & + & $?$ \\
\hline Cooper 1996 & ? & $?$ & $?$ & - \\
\hline Desjardins 2004 & + & ? & $\odot$ & $?$ \\
\hline Herbertson 1995 & ? & $?$ & $?$ & $?$ \\
\hline Hersh 2004 & + & $?$ & + & $?$ \\
\hline Hofele 2006 & + & $?$ & $?$ & $?$ \\
\hline Kubitzek 2003 & $?$ & $?$ & $\odot$ & $?$ \\
\hline Manvelian 2012a & ? & $?$ & $?$ & $?$ \\
\hline Mehlisch 1995 & ? & $?$ & + & $?$ \\
\hline Nelson 1994 & $?$ & $?$ & $?$ & - \\
\hline Olson 1997 & + & $?$ & + & $?$ \\
\hline Riff 2009 & $?$ & $?$ & $?$ & $?$ \\
\hline Torres 2004 & $?$ & $?$ & $?$ & $?$ \\
\hline Zuniga 2004 & + & - & $?$ & 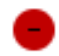 \\
\hline Zuniga 2010 & $?$ & $?$ & $?$ & $?$ \\
\hline
\end{tabular}




\section{Blinding}

Few studies adequately described the method of double-blinding (Figure 2 and Figure 3 ).

\section{Other potential sources of bias}

Small size was an issue in 5 of the 18 studies (Figure 2 and Figure 3 ).

\section{Effects of interventions}

See: Summary of findings for the main comparison

Efficacy outcomes were at least $50 \%$ of maximum pain relief over six hours, and remedication rates within six or eight hours. We have provided these by formulation, and within each formulation by dose of diclofenac. For adverse events we used all events reported within 24 hours of dosing, and pooled data for all doses together for different formulations. We did not carry out analyses on a small pilot study of a nanoparticle formulation (Manvelian 2012a), or a study using a $75 \mathrm{mg}$ dose of diclofenac sodium (Torres 2004).

Results for individual studies are in Appendix 5 (analgesia and use of rescue medication) and Appendix 6 (adverse events and withdrawals).

\section{Participants with at least $50 \%$ pain relief}

\section{Fast-acting diclofenac formulations}

Fast-acting formulations included dispersible tablets (Ahlstrom 1993; Bakshi 1994), soluble diclofenac in a sachet (Hofele 2006), and softgel formulations (Riff 2009; Zuniga 2004; Zuniga 2010).

\section{Diclofenac $25 \mathrm{mg}$ versus placebo}

Two studies (325 participants) included comparisons of fast-acting diclofenac 25 mg with placebo (Riff 2009; Zuniga 2010).

- The proportion of participants with at least $50 \%$ pain relief with fast-acting diclofenac $25 \mathrm{mg}$ was $22 \%$ (36/165, range $21 \%$ to $24 \%)$.

- The proportion of participants with at least $50 \%$ pain relief with placebo was $3 \%$ (4/160, range $2 \%$ to $3 \%)$.

- The relative benefit of treatment compared with placebo was 8.7 ( $95 \% \mathrm{Cl} 3.2$ to 24$)$; the NNT for one additional participant to benefit compared with placebo was 5.2 (3.8 to 8.0) (Analysis 1.1).

\section{Diclofenac $50 \mathrm{mg}$ versus placebo}

Four studies (486 participants) included comparisons of fast-acting diclofenac 50 mg with placebo (Ahlstrom 1993; Bakshi 1994; Hofele 2006; Zuniga 2010).

- The proportion of participants with at least $50 \%$ pain relief with fast-acting diclofenac $50 \mathrm{mg}$ was $61 \%$ (156/254, range $29 \%$ to $75 \%)$.

- The proportion of participants with at least $50 \%$ pain relief with placebo was $20 \%$ (46/232, range $2 \%$ to $38 \%$ ).

- The relative benefit of treatment compared with placebo was 2.9 (2.2 to 3.8); the NNT for one additional participant to benefit compared with placebo was 2.4 (2.0 to 3.0) (Analysis 1.1). was below our threshold of 200 participants for any subgroup analysis, but was included here for completeness.

- The proportion of participants with at least $50 \%$ pain relief with fast-acting diclofenac $100 \mathrm{mg}$ was 38\% (35/92, range 30\% to $55 \%)$.

- The proportion of participants with at least $50 \%$ pain relief with placebo was $1 \%(1 / 76$, range $0 \%$ to $2 \%)$.

- The relative benefit of treatment compared with placebo was 18 (3.6 to 91); the NNT for one additional participant to benefit compared with placebo was 2.7 (2.1 to 3.8) (Analysis 1.1).

\section{Diclofenac potassium}

\section{Diclofenac $25 \mathrm{mg}$ versus placebo}

Four studies (502 participants) included comparisons of diclofenac potassium 25 mg with placebo (Hersh 2004; Kubitzek 2003; Nelson 1994; Olson 1997).

- The proportion of participants with at least $50 \%$ pain relief with diclofenac potassium $25 \mathrm{mg}$ was 56\% (140/248, range $46 \%$ to $68 \%)$.

- The proportion of participants with at least $50 \%$ pain relief with placebo was $15 \%$ (37/254, range $8 \%$ to $29 \%)$.

- The relative benefit of treatment compared with placebo was 3.9 (2.8 to 5.3); the NNT for one additional participant to benefit compared with placebo was 2.4 (2.0 to 2.9) (Analysis 2.1).

\section{Diclofenac $50 \mathrm{mg}$ versus placebo}

Seven studies (757 participants) included comparisons of diclofenac potassium $50 \mathrm{mg}$ with placebo (Bakshi 1992; Herbertson 1995; Hersh 2004; Hofele 2006; Mehlisch 1995; Nelson 1994; Olson 1997).

- The proportion of participants with at least $50 \%$ pain relief with diclofenac potassium $50 \mathrm{mg}$ was $64 \%$ (253/398, range $53 \%$ to $74 \%)$.

- The proportion of participants with at least $50 \%$ pain relief with placebo was $17 \%$ (60/359, range $8 \%$ to $29 \%$ ).

- The relative benefit of treatment compared with placebo was 3.7 (2.9 to 4.7); the NNT for one additional participant to benefit compared with placebo was 2.1 (1.9 to 2.5) (Analysis 2.1).

\section{Diclofenac $100 \mathrm{mg}$ versus placebo}

Six studies (594 participants) included comparisons of diclofenac potassium 100 mg with placebo (Herbertson 1995; Hersh 2004; Mehlisch 1995; Nelson 1994; Olson 1997; Zuniga 2004).

- The proportion of participants with at least $50 \%$ pain relief with diclofenac potassium $100 \mathrm{mg}$ was $65 \%$ (196/305, range $45 \%$ to $73 \%)$.

- The proportion of participants with at least $50 \%$ pain relief with placebo was $13 \%$ (39/289, range $0 \%$ to $29 \%)$.

- The relative benefit of treatment compared with placebo was 4.8 (3.6 to 6.5); the NNT for one additional participant to benefit compared with placebo was 1.9 (1.7 to 2.3) (Analysis 2.1).

\section{Diclofenac $100 \mathrm{mg}$ versus placebo}

Two studies (168 participants) included comparisons of fast-acting diclofenac $100 \mathrm{mg}$ with placebo (Zuniga 2004; Zuniga 2010). This 


\section{Diclofenac sodium}

\section{Diclofenac $50 \mathrm{mg}$ versus placebo}

Three studies (284 participants) included comparisons of diclofenac sodium 50 mg with placebo (Bakshi 1992; Chang 2002; Cooper 1996).

- The proportion of participants with at least $50 \%$ pain relief with diclofenac sodium $50 \mathrm{mg}$ was $30 \%$ (58/193, range $26 \%$ to $56 \%$ ).

- The proportion of participants with at least $50 \%$ pain relief with placebo was $15 \%$ (18/120, range $0 \%$ to $22 \%)$.

- The relative benefit of treatment compared with placebo was 2.0 (1.3 to 3.3); the NNT for one additional participant to benefit compared with placebo was 6.6 (4.1 to 17) (Analysis 3.1).

\section{Time to remedication}

This outcome examined the time from taking study medication to use of rescue medication. Most studies asked participants to wait one or two hours after taking study medication before taking rescue medication. Short times indicate large numbers of participants with inadequate pain relief (treatment failures), and longer times indicate the duration of analgesia. Not all studies reported relevant data; of those that did, most reported median times to remedication, and a few reported mean times.

\section{Fast-acting diclofenac formulations}

For the $50 \mathrm{mg}$ dose, the mean time to use of rescue medication was 7.6 hours for diclofenac and 3.8 hours for placebo (two studies, 349 participants; Bakshi 1994; Hofele 2006).

\section{Diclofenac potassium}

For the $25 \mathrm{mg}$ dose, the median time to use of rescue medication was 3.1 hours for diclofenac and 1.2 hours for placebo (5 studies, 625 participants; Hersh 2004; Kubitzek 2003; Nelson 1994; Olson 1997; Zuniga 2010).

For the $50 \mathrm{mg}$ dose, the median time to use of rescue medication was 4.5 hours for diclofenac and 1.7 hours for placebo ( 5 studies, 566 participants; Hersh 2004; Mehlisch 1995; Nelson 1994; Olson 1997; Zuniga 2010).

For the $100 \mathrm{mg}$ dose, the median time to use of rescue medication was 6.3 hours for diclofenac and 2.0 hours for placebo $(6$ studies, 611 participants; Hersh 2004; Mehlisch 1995; Nelson 1994; Olson 1997; Zuniga 2004; Zuniga 2010).

\section{Diclofenac sodium}

One study using a $50 \mathrm{mg}$ dose in dental pain reported a median time to use of rescue medication of 1.6 hours for both diclofenac and placebo (105 participants; Chang 2002). Another study reported a mean time to use of rescue medication of 4.7 hours for diclofenac and 2.1 hours for placebo (70 participants; Cooper 1996)

One study using a $100 \mathrm{mg}$ dose in bunionectomy pain reported a median time to use of rescue medication of 2.1 hours for diclofenac and 1.4 hours for placebo (252 participants; Desjardins 2004).

\section{Participants remedicating within six to eight hours}

This outcome examined the need for additional analgesia in the period immediately after taking the test medications.

\section{Fast-acting diclofenac formulation}

\section{Diclofenac $50 \mathrm{mg}$ versus placebo}

Four studies (486 participants) included comparisons of fast-acting diclofenac 50 mg with placebo (Ahlstrom 1993; Bakshi 1994; Hofele 2006; Zuniga 2010).

- The proportion of participants remedicating with fast-acting diclofenac $50 \mathrm{mg}$ was 33\% (83/254, range $24 \%$ to $40 \%$ ).

- The proportion of participants remedicating with placebo was $71 \%$ (164/232, range $65 \%$ to $78 \%)$.

- The relative benefit of treatment compared with placebo was 0.46 ( 0.38 to 0.56 ); the NNTp for one additional participant not to need to remedicate compared with placebo was 2.6 (2.2 to 3.4 ) (Analysis 1.2).

\section{Diclofenac $100 \mathrm{mg}$ versus placebo}

Two studies (168 participants) included comparisons of fast-acting diclofenac 100 mg with placebo (Zuniga 2004; Zuniga 2010).

- The proportion of participants remedicating with fast-acting diclofenac $100 \mathrm{mg}$ was $50 \%$ (46/92, range $40 \%$ to $72 \%$ ).

- The proportion of participants remedicating with placebo was $78 \%$ (59/76, range $72 \%$ to $100 \%)$.

- The relative benefit of treatment compared with placebo was 0.61 (0.48 to 0.77 ); the NNTp for one additional participant not to need to remedicate compared with placebo was 3.6 (2.4 to 7.3 ) (Analysis 1.2).

\section{Diclofenac potassium}

\section{Diclofenac $25 \mathrm{mg}$ versus placebo}

Four studies (502 participants) included comparisons of diclofenac potassium 25 mg with placebo (Riff 2009; Zuniga 2010).

- The proportion of participants remedicating with diclofenac potassium $25 \mathrm{mg}$ was $51 \%$ (127/248, range $4 \%$ to $77 \%$ ).

- The proportion of participants remedicating with placebo was $71 \%$ (181/254, range $37 \%$ to $89 \%)$.

- The relative benefit of treatment compared with placebo was 0.72 ( 0.63 to 0.82 ); the NNTp for one additional participant not to need to remedicate compared with placebo was 5.0 (3.5 to 8.5) (Analysis 2.2).

\section{Diclofenac $50 \mathrm{mg}$ versus placebo}

Seven studies (757 participants) included comparisons of diclofenac potassium $50 \mathrm{mg}$ with placebo (Bakshi 1992; Herbertson 1995; Hersh 2004; Hofele 2006; Mehlisch 1995; Nelson 1994; Olson 1997).

- The proportion of participants remedicating with diclofenac potassium $50 \mathrm{mg}$ was $36 \%$ (144/398, range $8 \%$ to $50 \%$ ).

- The proportion of participants remedicating with placebo was $69 \%$ (248/359, range $37 \%$ to $83 \%)$

- The relative benefit of treatment compared with placebo was 0.52 ( 0.45 to 0.60$)$; the NNTp for one additional participant not to need to remedicate compared with placebo was 3.0 (2.5 to 3.8) (Analysis 2.2). 


\section{Diclofenac $100 \mathrm{mg}$ versus placebo}

Six studies (589 participants) included comparisons of diclofenac potassium $100 \mathrm{mg}$ with placebo (Herbertson 1995; Hersh 2004; Mehlisch 1995; Nelson 1994; Olson 1997; Zuniga 2004).

- The proportion of participants remedicating with diclofenac potassium $100 \mathrm{mg}$ was $34 \%$ (103/300, range $0 \%$ to $76 \%$ ).

- The proportion of participants remedicating with placebo was $72 \%$ (208/289, range $37 \%$ to $100 \%)$.

- The relative benefit of treatment compared with placebo was 0.45 ( 0.38 to 0.54 ); the NNTp for one additional participant not to need to remedicate compared with placebo was 2.6 (2.2 to 3.3 ) (Analysis 2.2).

\section{Diclofenac sodium}

\section{Diclofenac $50 \mathrm{mg}$ versus placebo}

Two studies (284 participants) included comparisons of diclofenac sodium 50 mg with placebo (Bakshi 1992; Chang 2002).

- The proportion of participants remedicating with diclofenac sodium $50 \mathrm{mg}$ was $59 \%$ (103/175, range $41 \%$ to $67 \%$ ).

- The proportion of participants remedicating with placebo was $69 \%$ ( $75 / 109$, range $59 \%$ to $76 \%)$.

- The relative benefit of treatment compared with placebo was 0.82 (95\% Cl 0.69 to 0.98); the NNTp for one additional participant not to need to remedicate compared with placebo was not calculated because of the bare statistical significance (Analysis 3.2).

\section{Adverse events}

Not all studies reported the number of participants experiencing any adverse event in the 24 hours after dosing.

\section{Fast-acting diclofenac formulations}

Five studies (636 participants) included comparisons of fast-acting diclofenac formulations with placebo (Ahlstrom 1993; Bakshi 1994; Hofele 2006; Zuniga 2004; Zuniga 2010).

- The proportion of participants reporting an adverse event with fast-acting diclofenac formulations was $8 \%$ (34/409, range $3 \%$ to $17 \%)$.

- The proportion of participants reporting an adverse event with placebo was $7 \%$ (17/227, range $5 \%$ to $11 \%)$.

- The relative benefit of treatment compared with placebo was 1.0 (0.60 to 1.8); the NNH was not calculated (Analysis 4.1).

\section{Diclofenac potassium}

Seven studies (1090 participants) included comparisons of diclofenac potassium with placebo (Bakshi 1992; Herbertson 1995; Hersh 2004; Hofele 2006; Nelson 1994; Olson 1997; Zuniga 2004).

- The proportion of participants reporting an adverse event with diclofenac potassium was $8 \%$ (60/765, range $1 \%$ to $16 \%)$.

- The proportion of participants reporting an adverse event with placebo was $7 \%$ (24/325, range $2 \%$ to $15 \%)$.

- The relative benefit of treatment compared with placebo was 1.0 (0.66 to 1.6); the NNH was not calculated (Analysis 4.1).

\section{Diclofenac sodium}

Only one study reported adverse events; $3 / 51$ and $3 / 46$ participants reported treatment-related adverse events with diclofenac $50 \mathrm{mg}$ and placebo, respectively (Bakshi 1992).

\section{Serious adverse events}

No study reported any serious adverse events with single dose treatment. One study reported a serious event (asthma flare) in a participant given placebo (Chang 2002), but it is not clear whether this occurred during the single or multiple dose phase.

\section{Withdrawals}

Three studies reported withdrawals due to adverse events. Chang 2002 reported withdrawal of one placebo-treated participant due to an asthma flare (see 'Serious adverse events', above). Desjardins 2004 reported withdrawal of one participant treated with diclofenac $100 \mathrm{mg}$ and three participants treated with placebo, but did not provide specific details. Herbertson 1995 reported withdrawal of eight participants in total, one of whom was treated with diclofenac $100 \mathrm{mg}$ and experienced nausea and vomiting.

\section{DISCUSSION}

The original version of this review included seven studies, in which 581 participants were treated with diclofenac and 364 with placebo (Barden 2004). An updated review included 15 studies, with 1512 participants treated with diclofenac and 793 with placebo (Derry 2009a). This further update included 18 studies, with 1902 participants treated with diclofenac and 1007 with placebo, representing a $26 \%$ increase in participants in comparisons between diclofenac and placebo.

In addition to including more studies and participants, this update also changed the focus of the review, examining the effects of formulation in more detail than previously. This is a result of increased understanding of the importance of speed of onset in determining analgesic efficacy in acute pain (Moore 2014; Moore 2015a). Fast-acting diclofenac formulations, fast-acting gelatin capsules, or nanoparticles produce maximum plasma concentrations at about 15 to 40 minutes (Chen 2015; Manvelian 2012b; Scallion 2009), similar to diclofenac potassium, at around 30 to 40 minutes (Chen 2015), but much faster than diclofenac sodium, where maximum plasma concentrations are reported to be longer than 2 hours (Willis 1979).

These results relate to absorption in the fasted state. Taking drugs with food can have very significant effects on the absorption of drugs. For rapidly absorbed analgesics, maximum plasma concentrations are typically delayed and reduced in extent in the fed compared with the fasting state (Moore 2015b). This may not always be the case, as with some formulations of diclofenac (Chen 2015; Manvelian 2012b). The complexity of taking analgesics in the fed state does not impinge on the analgesic results in this (and other) acute pain reviews, as participants are almost universally fasted when taking the analgesics.

\section{Summary of main results}

The formulation with results from the largest number of studies and participants was diclofenac potassium. It demonstrated a graded improvement in efficacy as doses rose from $25 \mathrm{mg}$ to $100 \mathrm{mg}$, both for participants achieving at least 50\% maximum pain relief (which 
is what patients say they want from treatment; Moore 2013), and for remedication within 6 to 8 hours (see 'Summary of results A' below). The largest body of information, for diclofenac potassium $50 \mathrm{mg}$, in seven studies, produced a NNT for at least $50 \%$ of maximum pain relief compared with placebo of 2.1 (1.9 to 2.5), which is amongst the better results found in acute pain studies (Moore 2011a).

Fast-acting diclofenac preparations, of which there were various forms, were less frequently studied. A $50 \mathrm{mg}$ dose, in four studies, produced a similar NNT to diclofenac potassium, of 2.4 (2.0 to 3.0). The results for the $100 \mathrm{mg}$ dose derive from only 168 participants and therefore should be interpreted with caution. We have included this analysis, despite having fewer than 200 participants, for indicative purposes only.

We found few data for diclofenac sodium, and the NNT compared with placebo was high, at 6.6 (4.1 to 17). This probably reflects its much slower absorption than diclofenac potassium or fast-acting formulations.

Adverse events rates for all formulations were very similar to those with placebo. Serious adverse events were not reported, or did not occur. 


\begin{tabular}{|c|c|c|c|c|c|c|c|}
\hline \multicolumn{8}{|c|}{$\overbrace{0}^{\varrho} \stackrel{\varrho}{=}$ Summary of results $A$} \\
\hline \multicolumn{8}{|c|}{ Percent with outcome } \\
\hline Formulation & $\begin{array}{l}\text { Dose } \\
\text { (mg) }\end{array}$ & $\begin{array}{l}\text { Number of } \\
\text { studies }\end{array}$ & Participants & Diclofenac & Placebo & $\begin{array}{l}\text { RR } \\
(95 \% \mathrm{Cl})\end{array}$ & $\begin{array}{l}\text { NNT } \\
(95 \% \mathrm{Cl})\end{array}$ \\
\hline \multicolumn{8}{|c|}{ At least $50 \%$ maximum pain relief over 6 hours } \\
\hline \multirow[t]{3}{*}{ Fast acting } & 25 & 2 & 325 & 22 & 3 & 8.7 (3.2 to 24$)$ & $5.2(3.8$ to 8.0$)$ \\
\hline & 50 & 4 & 486 & 61 & 20 & $2.9(2.2$ to 3.8$)$ & 2.4 (2.0 to 3.0$)$ \\
\hline & 100 & 2 & 168 & 38 & 1 & 18 (3.6 to 91$)$ & 2.7 (2.1 to 3.8$)$ \\
\hline \multirow{3}{*}{$\begin{array}{l}\text { Diclofenac potas- } \\
\text { sium }\end{array}$} & 25 & 4 & 502 & 56 & 15 & $3.9(2.8$ to 5.3$)$ & 2.4 (2.0 to 2.9$)$ \\
\hline & 50 & 7 & 757 & 64 & 17 & $3.7(2.9$ to 4.7$)$ & 2.1 (1.9 to 2.5$)$ \\
\hline & 100 & 6 & 594 & 67 & 13 & 5.1 (3.7 to 6.8$)$ & $1.9(1.7$ to 2.1$)$ \\
\hline $\begin{array}{l}\text { Diclofenac sodi- } \\
\text { um }\end{array}$ & 50 & 3 & 313 & 30 & 15 & $2.0(1.3$ to 3.3$)$ & $6.6(4.1$ to 17$)$ \\
\hline \multicolumn{7}{|c|}{ Remedication within 6 to 8 hours } & $\begin{array}{l}\text { NNTp } \\
(95 \% \mathrm{Cl})\end{array}$ \\
\hline \multirow[t]{2}{*}{ Fast acting } & 50 & 4 & 486 & 33 & 71 & 0.46 ( 0.38 to 0.56$)$ & $2.6(2.2$ to 3.4$)$ \\
\hline & 100 & 2 & 168 & 50 & 78 & 0.61 (0.48 to 0.77$)$ & $3.6(2.4$ to 7.3$)$ \\
\hline \multirow{3}{*}{$\begin{array}{l}\text { Diclofenac potas- } \\
\text { sium }\end{array}$} & 25 & 4 & 502 & 51 & 71 & 0.72 (0.63 to 0.82$)$ & $5.0(3.5$ to 8.5$)$ \\
\hline & 50 & 7 & 757 & 36 & 69 & 0.52 (0.45 to 0.60$)$ & $3.0(2.5$ to 3.8$)$ \\
\hline & 100 & 6 & 594 & 34 & 72 & 0.45 (0.38 to 0.54$)$ & $2.6(2.2$ to 3.3$)$ \\
\hline $\begin{array}{l}\text { Diclofenac sodi- } \\
\text { um }\end{array}$ & 50 & 2 & 284 & 59 & 69 & 0.82 (0.69 to 0.98$)$ & not calculated \\
\hline
\end{tabular}




\section{Overall completeness and applicability of evidence}

The main limitation of the review was the small number of studies and participants for most analyses. The limited number of studies and participants did not allow for any sensible assessment of common or rare adverse events, although diclofenac is widely studied in other conditions, particularly chronic musculoskeletal pain, such as occurs with osteoarthritis.

Some important outcomes, such as those concerning duration of pain relief, were very poorly reported. Some results were available, but studies frequently did not report median time to duration, or percentages of participants who needed additional analgesia by particular times, or by the end of the study.

\section{Quality of the evidence}

The studies themselves were of high quality, but sample sizes were somewhat limited. The biggest problem was that studies did not report key methodological information about randomisation and blinding, though our experience is that these studies are usually done impeccably. This lack of methodological detail was true even for the most recent studies, and reflects a lack of awareness by authors, journals, and sponsors, about how clinical trials should be reported.

\section{Potential biases in the review process}

We carried out extensive searches to identify relevant studies, but there always remains the possibility of unidentified studies. For the largest data set, diclofenac potassium $50 \mathrm{mg}$, a very large amount of null effect data would be required to reduce the analgesic effect to a clinically irrelevant value of 8 (Moore 2008); over 2100 participants would be needed in null effect studies to do this. It is unlikely that such a body of evidence exists. That would not be the case for fast-acting formulations, where the amount of data for any one formulation is small, and particularly for diclofenac sodium, where analgesic efficacy is modest and the data available very few.

\section{Agreements and disagreements with other studies or reviews}

Previous versions of this review, and other reviews, have not reported results according to formulation, as done here, making comparison difficult. The overall estimate of efficacy for $50 \mathrm{mg}$ diclofenac for at least $50 \%$ maximum pain relief in the previous version of this review was 2.7 (2.4 to 3.0). This compares with a NNT of 2.1 (1.9 to 2.5 ) for $50 \mathrm{mg}$ diclofenac potassium in this review, a significantly better result $(z=2.28, P=0.023)$. Including sloweracting formulations like diclofenac sodium in previous reviews probably erroneously underestimated analgesic efficacy possible with some forms of the drug.

\section{AUTHORS' CONCLUSIONS}

\section{Implications for practice}

\section{For people with moderate to severe acute pain}

Diclofenac potassium provides good pain relief at $25 \mathrm{mg}, 50 \mathrm{mg}$, and $100 \mathrm{mg}$ doses. Choice of dose may depend on the situation. Diclofenac sodium has limited efficacy and should probably not be used in acute pain.

\section{For clinicians}

Diclofenac potassium provides good pain relief at $25 \mathrm{mg}, 50 \mathrm{mg}$, and $100 \mathrm{mg}$ doses. Choice of dose may depend on the situation. Diclofenac sodium has limited efficacy and should probably not be used in acute pain.

\section{For policy makers}

Diclofenac sodium has limited efficacy and should probably not be used in acute pain. It is not clear if this is widely recognised. Diclofenac potassium is among the most effective analgesics in acute pain.

\section{For Funders}

Diclofenac sodium has limited efficacy and should probably not be used in acute pain. Diclofenac potassium is among the most effective analgesics in acute pain.

\section{Implications for research}

\section{General}

This review confirms other research indicating that rapidly dispersible and absorbed analgesics provide good pain relief, and that slow absorption results in poor pain relief in acute pain. Formulation is therefore of major consequence, and while the evidence on this is growing, there remain considerable gaps in our knowledge. These include direct linking of pharmacokinetics and pharmacodynamics in acute pain, something readily amenable to test in relatively inexpensive clinical trials.

Research could, and probably should, include effects of fasting and fed states for acute pain and headache, especially in situations where many over-the-counter drugs are taken. The effects of food on drug absorption and analgesics efficacy are not well understood, but they are significant.

\section{Design}

The current design of acute pain studies is well understood, and has proven to be robust.

\section{Measurement (endpoints)}

Endpoints in these studies have been extensively validated, as have standard pain scoring systems. The main outcome used is one valued by people with pain, and has economic benefits in most circumstances.

\section{Comparison between active treatments}

The standardised nature of the study design means that indirect comparisons with placebo are valid, as evidenced by independent research on the topic. There is, however, a very large body of information amenable to network meta-analysis. While unlikely to provide much in the way of new insights, it could prove an invaluable tool for testing network meta-analytical methods.

\section{Reporting}

The continued omission of details about methods, such as how the random sequence was generated and how its allocation was concealed, should be addressed. 


\section{ACK N OWLEDGEMENTS}

Jodie Barden (JB) and Jayne Edwards (JE) were authors on the earliest review, and Philip Derry (PD) and Henry McQuay (HM) were authors on the immediately previous review.
This review received infrastructure support from the Oxford Pain Relief Trust.

The National Institute for Health Research (NIHR) is the largest single funder of the Cochrane Pain, Palliative and Supportive Care Review Group. Disclaimer: The views and opinions expressed therein are those of the authors and do not necessarily reflect those of the NIHR, National Health Service, or the Department of Health. 


\section{R E F E R E N C E S}

\section{References to studies included in this review}

\section{Ahlstrom 1993 \{published data only\}}

Ahlstrom U, Bakshi R, Nilsson P, Wahlander L. The analgesic efficacy of diclofenac dispersible and ibuprofen in postoperative pain after dental extraction. European Journal of Clinical Pharmacology 1993;44(6):587-8.

\section{Bakshi 1992 \{published data only\}}

Bakshi R, Jacobs LD, Lehnert S, Picha B, Reuther J. A doubleblind, placebo controlled trial comparing the analgesic efficacy of two formulations of diclofenac in postoperative dental pain. Current Therapeutic Research 1992;52(3):435-42.

Bakshi 1994 \{published data only\}

Bakshi R, Frenkel G, Dietlein G, Meurer Witt B, Schneider B, Sinterhauf U. A placebo-controlled comparative evaluation of diclofenac dispersible versus ibuprofen in postoperative pain after third molar surgery. Journal of Clinical Pharmacology 1994;34(3):225-30.

\section{Chang 2002 \{published data only\}}

Chang DJ, Desjardins PJ, Chen E, Polis AB, McAvoy M, Mockoviak SH, et al. Comparison of the analgesic efficacy of rofecoxib and enteric-coated diclofenac sodium in the treatment of postoperative dental pain: a randomized, placebo-controlled clinical trial. Clinical Therapeutics 2002;24(4):490-503.

\section{Cooper 1996 \{published data only\}}

Cooper SA, Cowan A, Tallarida RJ, Hargreaves K, Roszkowski M, Jamali $F$, et al. The analgesic interaction of misoprostol with nonsteroidal anti-inflammatory drugs. American Journal of Therapeutics 1996;3(4):261-7.

\section{Desjardins 2004 \{published data only\}}

Desjardins PJ, Black PM, Daniels S, Bird SR, Fitzgerald BJ, Petruschke RA, et al. A randomized controlled study comparing rofecoxib, diclofenac sodium, and placebo in postbunionectomy pain. Current Medical Research and Opinion 2004;20(10):1523-37.

\section{Herbertson 1995 \{published data only\}}

Herbertson RM, Storey N. The comparative efficacy of diclofenac potassium, aspirin and placebo in the treatment of patients with pain following gynecologic surgery. Today's Therapeutic Trends 1995;12(Suppl 1):33-45.

\section{Hersh 2004 \{published data only\}}

Hersh EV, Levin LM, Adamson D, Christensen S, Kiersch TA, Noveck R, et al. Dose-ranging analgesic study of Prosorb diclofenac potassium in postsurgical dental pain. Clinical Therapeutics 2004;26(8):1215-27. [DOI: 10.1016/ S0149-2918(04)80033-X]

\section{Hofele 2006 \{published data only\}} Hofele CM, Gyenes V, Daems LN, Stypula-Ciuba B, Wagener H, et al. Efficacy and tolerability of diclofenac potassium sachets in acute postoperative dental pain: a placebo- controlled, randomised, comparative study vs. diclofenac potassium tablets. International Journal of Clinical Practice 2006;60(3):300-7. [DOI: 10.1111/j.1368-5031.2006.00828.x]

Kubitzek 2003 \{published data only\}

Kubitzek F, Ziegler G, Gold MS, Liu JM, Ionescu E. Analgesic efficacy of low-dose diclofenac versus paracetamol and placebo in postoperative dental pain. Journal of Orofacial Pain 2003;17(3):237-44.

\section{Manvelian 2012a \{published data only\}}

Manvelian G, Daniels S, Gibofsky A. A phase 2 study evaluating the efficacy and safety of a novel, proprietary, nano-formulated, lower dose oral diclofenac. Pain Medicine 2012;13(11):1491-8. [DOI: 10.1111/j.1526-4637.2012.01479.x]

Mehlisch 1995 \{published data only\}

Mehlisch DR, Brown P. Single-dose therapy with diclofenac potassium, aspirin or placebo following dental impaction surgery. Today's Therapeutic Trends 1995;12(Suppl 1):15-31.

\section{Nelson 1994 \{published data only\}}

Nelson S, Brahim J. An evaluation of the analgesic efficacy of diclofenac potassium, aspirin, and placebo in postoperative dental pain. Today's Therapeutic Trends 1994;12:3-14.

\section{Olson 1997 \{published data only\}}

Olson NZ, Sunshine A, Zighelboim I, DeCastro A. Onset and duration of analgesia of diclofenac potassium in the treatment of postepisiotomy pain. American Journal of Therapeutics 1997;4:239-46.

\section{Riff 2009 \{published data only\}}

Riff DS, Duckor S, Gottlieb I, Diamond E, Soulier S, Raymond G, et al. Diclofenac potassium liquid-filled soft gelatin capsules in the management of patients with postbunionectomy pain: a Phase III, multicenter, randomized, double-blind, placebocontrolled study conducted over 5 days. Clinical Therapeutics 2009;31(10):2072-85. [DOI: 10.1016/j.clinthera.2009.09.011]

\section{Torres 2004 \{published data only\}}

Torres LM, Cabrera J, Martínez J, Calderón E, Fernández S, Chaves J. The specific cox-2 inhibitor valdecoxib provides effective analgesia after inguinal hernia surgery. Revista Espanola Anestesiologia y Reanimacion 2004;51(10):576-82.

\section{Zuniga 2004 \{published data only\}}

Zuniga JR, Phillips CL, Shugars D, Lyon JA, Peroutka SJ, Swarbrick J, et al. Analgesic safety and efficacy of diclofenac sodium softgels on postoperative third molar extraction pain Journal of Oral Maxillofacial Surgery 2004;62(7):806-15. [DOI: 10.1016/j.joms.2003.12.019]

\section{Zuniga 2010 \{published data only\}}

Zuniga JR, Malmström H, Noveck RJ, Campbell JH, Christensen S, Glickman RS, et al. Controlled phase III clinical trial of diclofenac potassium liquid-filled soft gelatin capsule for treatment of postoperative dental pain. Journal of Oral 
and Maxillofacial Surgery 2010;68(11):2735-42. [DOI: 10.1016/ j.joms.2010.05.075.]

\section{References to studies excluded from this review}

Daniels 2012 \{published data only\}

Daniels SE, Riff D, Diamond E, Clark F, Boesing SE. An assessment of the efficacy and safety of diclofenac potassium liquid-filled capsules inpatients with various levels of baseline pain intensity. Current Medical Research \& Opinion 2012;28(6):953-61. [DOI: 10.1185/03007995.2012.694363]

\section{Zuniga 2011 \{published data only\}}

Zuniga JR, Noveck RJ, Schmidt WK, Boesing SE, Hersh EV. Onset of action of diclofenac potassium liquid-filled capsules in dental surgery patients. Current Medical Research and Opinion 2011;27(9):1733-9. [DOI: 10.1185/03007995.2011.600300]

\section{References to ongoing studies}

NCT01462435 \{published data only\}

NCT01462435. Study of diclofenac capsules to treat pain following bunionectomy. www.clinicaltrials.gov/ct2/results? term=NCT01462435+\&Search=Search (accessed 9 March 2015). [Clinicaltrials.gov: NCT01462435 ]

\section{Additional references}

\section{Chen 2015}

Chen C, Bujanover S, Kareht S, Rapoport AM. Differential pharmacokinetics of diclofenac potassium for oral solution vs immediate-release tablets from a randomized trial: effect of fed and fasting conditions. Headache 2015;55(2):265-75. [DOI: 10.1111/head.12483]

\section{Clarke 2012}

Clarke R, Derry S, Moore RA, McQuay HJ. Single dose oral etoricoxib for acute postoperative pain in adults. Cochrane Database of Systematic Reviews 2012, Issue 4. [DOI: 10.1002/14651858.CD004309.pub3]

\section{Collins 1997}

Collins SL, Moore RA, McQuay HJ. The visual analogue pain intensity scale: what is moderate pain in millimetres?. Pain 1997;72:95-7. [DOI: 10.1016/S0304-3959(97)00005-5]

\section{Collins 1998}

Collins SL, Moore RA, McQuay HJ, Wiffen PJ. Oral ibuprofen and diclofenac in postoperative pain: a quantitative systematic review. European Journal of Pain 1998;2(4):285-91. [DOI: 10.1016/S1090-3801(98)90027-1]

\section{Collins 2001}

Collins SL, Edwards JE, Moore RA, Smith LA, McQuay HJ. Seeking a simple measure of analgesia for mega-trials: is a single global assessment good enough?. Pain 2001;91(1-2):189-94. [DOI: 10.1016/S0304-3959(00)00435-8]

\section{Cook 1995}

Cook RJ, Sackett DL. The number needed to treat: a clinically useful measure of treatment effect. BMJ 1995;310:452-4. [DOI: 10.1136/bmj.310.6977.452]

\section{Cooper 1991}

Cooper SA. Single-dose analgesic studies: the upside and downside of assay sensitivity. In: Max MB, Portenoy RK, Laska EM editor(s). The design of analgesic clinical trials. Advances in Pain Research and Therapy. Vol. 18, New York: Raven Press, 1991:117-24.

\section{Dechartres 2013}

Dechartres A, Trinquart L, Boutron I, Ravaud P. Influence of trial sample size on treatment effect estimates: metaepidemiological study. BMJ 2013;346:f2304. [DOI: 10.1136/ bmj.f2304]

\section{Derry 2009b}

Derry C, Derry S, Moore RA, McQuay HJ. Single dose oral naproxen and naproxen sodium for acute postoperative pain in adults. Cochrane Database of Systematic Reviews 2009, Issue 1. [DOI: 10.1002/14651858.CD004234.pub3]

\section{Derry 2010}

Derry S, Moore RA, McQuay HJ. Single dose oral codeine, as a single agent, for acute postoperative pain in adults. Cochrane Database of Systematic Reviews 2010, Issue 4. [DOI: 10.1002/14651858.CD008099.pub2]

\section{Derry 2013a}

Derry CJ, Derry S, Moore RA. Single dose oral ibuprofen plus paracetamol (acetaminophen) for acute postoperative pain. Cochrane Database of Systematic Reviews 2013, Issue 6. [DOI: 10.1002/14651858.CD010210.pub2]

\section{Derry 2013b}

Derry S, Karlin SM, Moore RA. Single dose oral ibuprofen plus codeine for acute postoperative pain in adults. Cochrane Database of Systematic Reviews 2013, Issue 3. [DOI: 10.1002/14651858.CD010107.pub2]

\section{Derry 2013c}

Derry S, Derry CJ, Moore RA. Single dose oral ibuprofen plus oxycodone for acute postoperative pain in adults. Cochrane Database of Systematic Reviews 2013, Issue 6. [DOI: 10.1002/14651858.CD010289.pub2]

\section{Fineschi 1997}

Fineschi G, Tamburrelli FC, Francucci BM, Pisati R. Oral diclofenac dispersible provides a faster onset of analgesia than intramuscular ketorolac in the treatment of postoperative pain. Clinical Drug Investigation 1997;13:1-7.

\section{FitzGerald 2001}

FitzGerald GA, Patrono C. The coxibs, selective inhibitors of cyclooxygenase-2. The New England Journal of Medicine 2001;345(6):433-42. [DOI: 10.1056/NEJM200108093450607] 


\section{Forrest 2002}

Forrest JB, Camu F, Greer IA, Kehlet H, Abdalla M, Bonnet F. Ketorolac, diclofenac, and ketoprofen are equally safe for pain relief after major surgery. British Journal of Anaesthesia 2002;88(2):227-33. [DOI: 10.1093/bja/88.2.227]

\section{Grahame-Smith 2002}

Grahame-Smith DG, Aronson JK. Oxford Textbook of Clinical Pharmacology and Drug Therapy. 3rd Edition. Oxford: Oxford University Press, 2002. [ISBN: 13: 978-0-19-263234-0]

\section{Hawkey 1999}

Hawkey CJ. Cox-2 inhibitors. The Lancet 1999;353(9149):307-14. [DOI: 10.1016/S0140-6736(98)12154-2]

\section{Hernández-Díaz 2001}

Hernández-Díaz S, García-Rodríguez LA. Epidemiologic assessment of the safety of conventional nonsteroidal anti-inflammatory drugs. American Journal of Medicine 2001;110(Suppl 3A):20S-7S. [DOI: 110.1016/ S0002-9343(00)00682-3]

\section{Higgins 2011}

Higgins JPT, Altman DG, Sterne JAC (editors). Assessing risk of bias in included studies. In: Higgins JPT, Green S (editors). Cochrane Handbook for Systematic Reviews of Interventions Version 5.1.0 [updated March 2011]. The Cochrane Collaboration, 2011. Available from www.cochranehandbook.org.

\section{Jadad 1996a}

Jadad AR, Carroll D, Moore A, McQuay H. Developing a database of published reports of randomised clinical trials in pain research. Pain 1996;66:239-46. [DOI: 10.1016/0304-3959(96)03033-3]

\section{Jadad 1996b}

Jadad AR, Moore RA, Carroll D, Jenkinson C, Reynolds DJM, Gavaghan DJ, et al. Assessing the quality of reports of randomized clinical trials: is blinding necessary?. Controlled Clinical Trials 1996;17:1-12. [DOI: 10.1016/0197-2456(95)00134-4]

\section{L'Abbé 1987}

L'Abbé KA, Detsky AS, O'Rourke K. Meta-analysis in clinical research. Annals of Internal Medicine 1987;107:224-33. [DOI: 10.7326/0003-4819-107-2-224]

\section{Manvelian 2012b}

Manvelian G, Daniels S, Gibofsky A. The pharmacokinetic parameters of a single dose of a novel nano-formulated, lower-dose oral diclofenac. Postgraduate Medicine 2012;124(1):117-23. [DOI: 10.3810/pgm.2012.01.2524]

\section{Martindale 2015}

Diclofenac. Martindale: The Complete Drug Reference (available at: medicinescomplete.com $/ \mathrm{mc} / \mathrm{martindale} /$ current $/ \mathrm{ms}$-13409w.htm?q=diclofenac\&t=search\&ss=text\&p=1\#_hit) (accessed 9 March 2015). The Pharmaceutical Press, 2015.

\section{McQuay 2005}

McQuay HJ, Moore RA. Placebo. Postgraduate Medical Journal 2005;81:155-60. [DOI: 10.1136/pgmj.2004.024737]

\section{McQuay 2012}

McQuay HJ, Derry S, Eccleston C, Wiffen PJ, Moore RA.

Evidence for analgesic effect in acute pain - 50 years on. Pain 2012;153(7):1364-7. [DOI: 10.1016/j.pain.2012.01.024]

\section{Moore 1997a}

Moore A, Moore O, McQuay H, Gavaghan D. Deriving dichotomous outcome measures from continuous data in randomised controlled trials of analgesics: use of pain intensity and visual analogue scales. Pain 1997;69(93):311-5. [DOI: 10.1016/S0304-3959(96)03306-4]

\section{Moore 1997b}

Moore A, McQuay H, Gavaghan D. Deriving dichotomous outcome measures from continuous data in randomised controlled trials of analgesics: verification from independent data. Pain 1997;69(1-2):127-30. [DOI: 10.1016/ S0304-3959(96)03251-4]

\section{Moore 1998}

Moore RA, Gavaghan D, Tramèr MR, Collins SL, McQuay HJ. Size is everything - large amounts of information are needed to overcome random effects in estimating direction and magnitude of treatment effects. Pain 1998;78(3):209-16. [DOI: 10.1016/S0304-3959(98)00140-7]

\section{Moore 2003}

Moore RA, Edwards J, Barden J, McQuay HJ. Bandolier's Little Book of Pain. Oxford: Oxford University Press, 2003. [ISBN: 0-19-263247-7]

\section{Moore 2005}

Moore RA, Edwards JE, McQuay HJ. Acute pain: individual patient meta-analysis shows the impact of different ways of analysing and presenting results. Pain 2005;116(3):322-31. [DOI: 10.1016/j.pain.2005.05.001]

\section{Moore 2006}

Moore A, McQuay H. Bandolier's Little Book of Making Sense of the Medical Evidence. Oxford: Oxford University Press, 2006. [ISBN: 0-19-856604-2]

\section{Moore 2008}

Moore RA, Barden J, Derry S, McQuay HJ. Managing potential publication bias. In: McQuay HJ, Kalso E, Moore RA editor(s). Systematic Reviews in Pain Research: Methodology Refined. Seattle: IASP Press, 2008:15-24. [ISBN: 978-0-931092-69-5]

\section{Moore 2011a}

Moore RA, Derry S, McQuay HJ, Wiffen PJ. Single dose oral analgesics for acute postoperative pain in adults. Cochrane Database of Systematic Reviews 2011, Issue 9. [DOI: 10.1002/14651858.CD008659.pub2]

\section{Moore 2011b}

Moore RA, Straube S, Paine J, Derry S, McQuay HJ. Minimum efficacy criteria for comparisons between treatments using 
individual patient meta-analysis of acute pain trials: examples of etoricoxib, paracetamol, ibuprofen, and ibuprofen/ paracetamol combinations after third molar extraction. Pain 2011;152(5):982-9. [DOI: 10.1016/j.pain.2010.11.030]

\section{Moore 2013}

Moore RA, Straube S, Aldington D. Pain measures and cut-offs - 'no worse than mild pain' as a simple, universal outcome. Anaesthesia 2013;68(4):400-12. [DOI: 10.1111/anae.12148]

\section{Moore 2014}

Moore RA, Derry S, Straube S, Ireson-Paine J, Wiffen PJ. Faster, higher, stronger? Evidence for formulation and efficacy for ibuprofen in acute pain. Pain 2014;155(1):14-21. [DOI: 10.1016/ j.pain.2013.08.013]

\section{Moore 2015a}

Moore RA, Derry S, Straube S, Ireson-Paine J, Wiffen PJ. Validating speed of onset as a key component of good analgesic response in acute pain. European Journal of Pain 2015;19(2):187-92. [DOI: 10.1002/ejp.536]

\section{Moore 2015b}

Moore RA, Derry S, Wiffen PJ, Staube S. Effects of food on pharmacokinetics of immediate release oral formulations of aspirin, dipyrone, paracetamol, and NSAIDs - systematic review. British Journal of Clinical Pharmacology 2015 Epub. [DOI: 10.1111/bcp.12628]

\section{Morris 1995}

Morris JA, Gardner MJ. Calculating confidence intervals for relative risk, odds ratio and standardised ratios and rates. In: Gardner MJ, Altman DG editor(s). Statistics With Confidence Confidence Intervals and Statistical Guidelines. London: British Medical Journal, 1995:50-63. [ISBN: 0-7279-0222-9]

\section{Nüesch 2010}

Nüesch E, Trelle S, Reichenbach S, Rutjes AW, Tschannen B, Altman DG, et al. Small study effects in meta-analyses of osteoarthritis trials: meta-epidemiological study. BMJ 2010;341:c3515. [DOI: 10.1136/bmj.c3515]

\section{PCA 2014}

Prescribing and Primary Care team, Health and Social Care Information Centre. Prescription Cost Analysis, England 2013. hscic.gov.uk/catalogue/PUB13887/pres-cost-anal-eng-2013rep.pdf (accessed 9 March 2015). [ISBN: 978-1-78386-089-0]

\section{Rapoport 1999}

Rapoport RJ. The safety of NSAIDs and related drugs for the management of acute pain: maximizing benefits and

\section{CHARACTERISTICS OF STUDIES}

Characteristics of included studies [ordered by study ID] minimizing risks. Cancer Control 1999;6(2 Suppl 1):18-21. [PUBMED: 12118235]

\section{RevMan 2014 [Computer program]}

Nordic Cochrane Centre, The Cochrane Collaboration. Review Manager (RevMan). Version 5.3. Copenhagen: Nordic Cochrane Centre, The Cochrane Collaboration, 2014.

\section{Scallion 2009}

Scallion R, Moore KA. Effects of food intake on the pharmacokinetics of diclofenac potassium soft gelatin capsules: a single-dose, randomized, two-way crossover study. Clinical Therapeutics 2009;31(10):2233-41. [DOI: 10.1016/ j.clinthera.2009.10.001]

\section{Toms 2008}

Toms L, McQuay HJ, Derry S, Moore RA. Single dose oral paracetamol (acetaminophen) for postoperative pain in adults. Cochrane Database of Systematic Reviews 2008, Issue 4. [DOI: 10.1002/14651858.CD004602]

\section{Tramèr 1997}

Tramèr MR, Reynolds DJM, Moore RA, McQuay HJ. Impact of covert duplicate results on meta-analysis: a case study. BMJ 1997;315:635-9. [DOI: 10.1136/bmj.315.7109.635]

\section{Willis 1979}

Willis JV, Kendall MJ, Flinn RM, Thornhill DP, Welling PG. The pharmacokinetics of diclofenac sodium following intravenous and oral administration. European Journal of Clinical Pharmacology 1979;16(6):405-10. [PUBMED: 527637]

\section{References to other published versions of this review}

\section{Barden 2004}

Barden J, Edwards J, Moore RA, McQuay HJ. Single dose oral diclofenac for postoperative pain. Cochrane Database of Systematic Reviews 2004, Issue 2. [DOI: 10.1002/14651858.CD004768]

\section{Collins 1999}

Collins SL, Moore RA, McQuay HJ, Wiffen PJ, Edwards JE. Single dose oral ibuprofen and diclofenac for postoperative pain. Cochrane Database of Systematic Reviews 1999, Issue 1. [DOI: 10.1002/14651858.CD001548]

\section{Derry 2009a}

Derry P, Derry S, Moore RA, McQuay HJ. Single dose oral diclofenac for acute postoperative pain in adults. Cochrane Database of Systematic Reviews 2009, Issue 2. [DOI: 10.1002/14651858.CD004768.pub2]

Ahlstrom 1993

Methods $\quad$ RCT, double-dummy, single oral dose, 3 parallel groups
Medication administered when baseline pain was of moderate to severe intensity


Ahlstrom 1993 (Continued)

Pain assessed at 0, 20, 40, 60 mins then hourly up to 6 hours

\begin{tabular}{|c|c|c|}
\hline \multirow[t]{4}{*}{ Participants } & \multicolumn{2}{|l|}{ Third molar extraction } \\
\hline & \multicolumn{2}{|l|}{$N=97$} \\
\hline & \multicolumn{2}{|l|}{$M=46, F=51$} \\
\hline & \multicolumn{2}{|l|}{ Mean age 25 years } \\
\hline \multirow[t]{3}{*}{ Interventions } & \multicolumn{2}{|c|}{ Diclofenac dispersible $50 \mathrm{mg}, \mathrm{n}=35$} \\
\hline & \multicolumn{2}{|c|}{ Ibuprofen (tablets) 400 mg, n= 32} \\
\hline & \multicolumn{2}{|l|}{ Placebo, $n=30$} \\
\hline \multirow[t]{3}{*}{ Outcomes } & \multicolumn{2}{|l|}{ PI: std 100 mm VAS } \\
\hline & \multicolumn{2}{|l|}{ PR: std $100 \mathrm{~mm}$ VAS } \\
\hline & \multicolumn{2}{|l|}{ PGE: std 5 point scale } \\
\hline \multirow[t]{2}{*}{ Notes } & \multicolumn{2}{|c|}{ Oxford Quality Score: R1, DB2, W1 } \\
\hline & \multicolumn{2}{|c|}{ No details about rescue medication used or any restrictions on time before use was permitted } \\
\hline \multicolumn{3}{|l|}{ Risk of bias } \\
\hline Bias & Authors' judgement & Support for judgement \\
\hline $\begin{array}{l}\text { Random sequence genera- } \\
\text { tion (selection bias) }\end{array}$ & Unclear risk & Not reported \\
\hline $\begin{array}{l}\text { Allocation concealment } \\
\text { (selection bias) }\end{array}$ & Unclear risk & Not reported \\
\hline $\begin{array}{l}\text { Blinding of participants } \\
\text { and personnel (perfor- } \\
\text { mance bias) } \\
\text { All outcomes }\end{array}$ & Low risk & Double-blind, double-dummy \\
\hline Size & High risk & $<50$ participants in treatment arms \\
\hline
\end{tabular}

Bakshi 1992

Methods

$\mathrm{RCT}$, DB, single dose, 3 parallel groups

Medication administered when baseline pain was of moderate to severe intensity

Pain assessed at $0,15,30$, and 60 mins then hourly up to 6 hours

\begin{tabular}{ll}
\hline Participants & Third molar extraction \\
& $\mathrm{N}=151$ \\
$\mathrm{M}=70, \mathrm{~F}=81$ \\
Mean age 26 years
\end{tabular}


Bakshi 1992 (Continued)

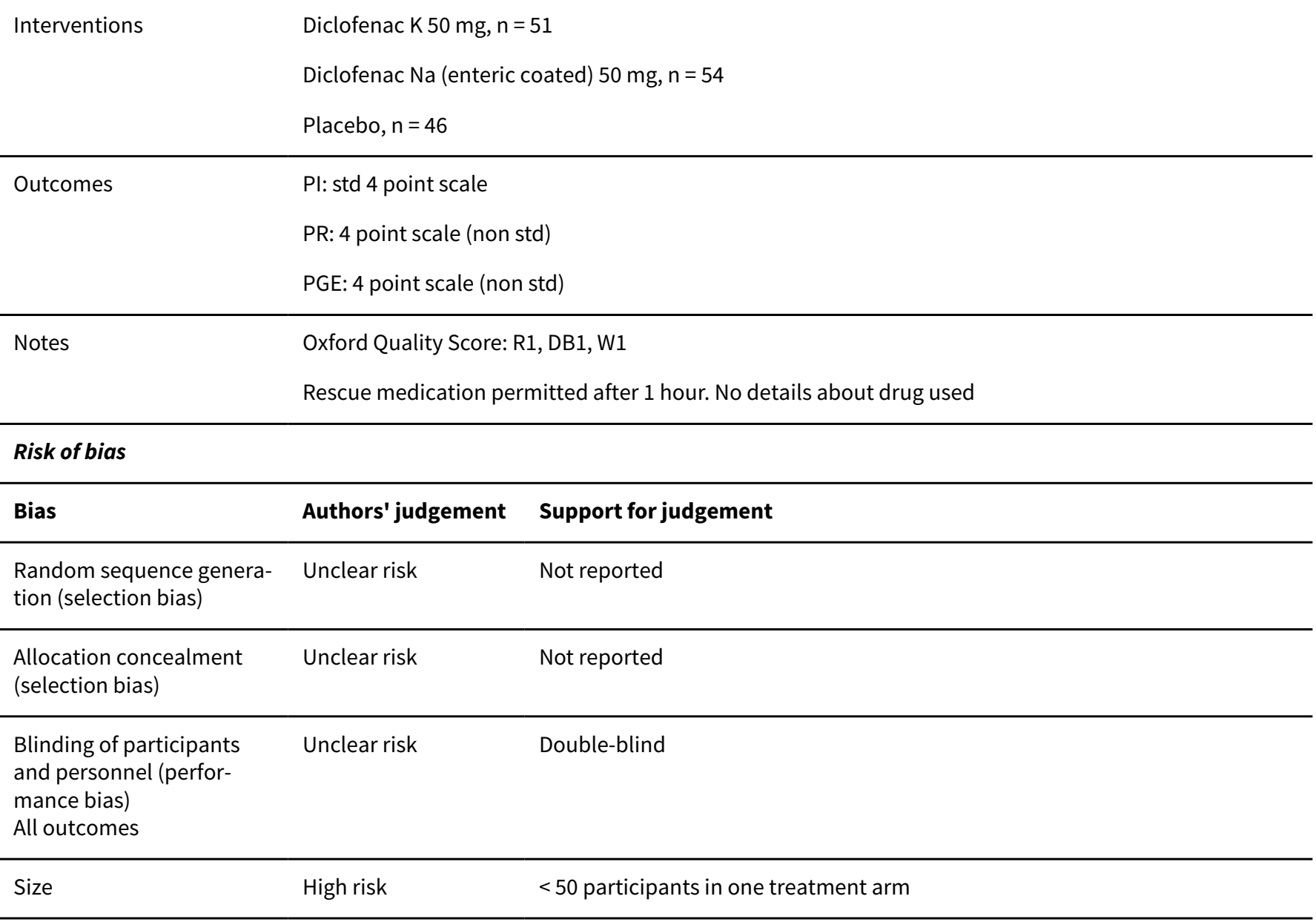

\section{Bakshi 1994}

Methods

$\mathrm{RCT}, \mathrm{DB}$, double-dummy, single oral dose, 3 parallel groups

Medication administered when baseline pain was of moderate to severe intensity

Pain assessed at $0,20,40,60,90,120$, and 150 mins then hourly up to 6 hours

\begin{tabular}{ll}
\hline Participants & Third molar extraction \\
& $\mathrm{N}=257$ \\
$\mathrm{M}=151, \mathrm{~F}=94$ \\
Mean age 27 years \\
\hline Interventions & Diclofenac free acid in dispersible preparation $50 \mathrm{mg}, \mathrm{n}=83$ \\
& Ibuprofen $400 \mathrm{mg}, \mathrm{n}=80$ \\
& Placebo, $\mathrm{n}=82$ \\
\hline Outcomes & Pl: std $100 \mathrm{~mm}$ VAS \\
PR: std 5 point scale
\end{tabular}


Bakshi 1994 (Continued)

PGE: 4 point (non std)

Notes $\quad$ Oxford Quality Score: R1 DB2, W1

Rescue medication permitted after 1 hour. No details of drug used

\section{Risk of bias}

\begin{tabular}{lll}
\hline Bias & Authors' judgement & Support for judgement \\
\hline $\begin{array}{l}\text { Random sequence genera- } \\
\text { tion (selection bias) }\end{array}$ & Unclear risk & Not reported \\
\hline $\begin{array}{l}\text { Allocation concealment } \\
\text { (selection bias) }\end{array}$ & Unclear risk & Not reported \\
\hline $\begin{array}{l}\text { Blinding of participants } \\
\text { and personnel (perfor- } \\
\text { mance bias) } \\
\text { All outcomes }\end{array}$ & Low risk & Double-blind, double-dummy \\
\hline Size & Unclear risk & $>50$ but $<200$ participants in treatment groups \\
\hline
\end{tabular}

Chang 2002

Methods

RCT, DB, double-dummy, 3 parallel groups, single and multiple oral dose phases

Medication administered when baseline pain was of moderate to severe intensity

Pain assessed at 0, 30, 60, 90, 120 mins, then hourly to 12 hours, then at 16, 20, 24 hours

\begin{tabular}{ll}
\hline Participants & Third molar extraction \\
& $\mathrm{N}=305$ \\
$\mathrm{M}=143, \mathrm{~F}=162$ & Mean age 23 years \\
\hline Interventions & Diclofenac $\mathrm{Na}$ (enteric coated) $50 \mathrm{mg}, \mathrm{n}=121$ \\
& Rofecoxib $50 \mathrm{mg}, \mathrm{n}=121$ \\
& Placebo, $\mathrm{n}=63$ \\
\hline Outcomes & PR: std 5 point scale \\
& PGE: std 5 point scale \\
& Numbers of participants using rescue medication \\
& Time to use of rescue medication \\
& Numbers with any adverse event \\
& Withdrawals \\
\hline
\end{tabular}


Chang 2002 (Continued)

Rescue medication permitted at any time (hydrocodone/paracetamol 5/500 mg)

\section{Risk of bias}

\begin{tabular}{lll}
\hline Bias & Authors' judgement & Support for judgement \\
\hline $\begin{array}{l}\text { Random sequence genera- } \\
\text { tion (selection bias) }\end{array}$ & Low risk & "computer generated allocation schedule" \\
\hline $\begin{array}{l}\text { Allocation concealment } \\
\text { (selection bias) }\end{array}$ & Unclear risk & Not reported \\
\hline $\begin{array}{l}\text { Blinding of participants } \\
\text { and personnel (perfor- } \\
\text { mance bias) } \\
\text { All outcomes }\end{array}$ & Low risk & "double-dummy technique with matching placebos" \\
\hline Size & & \\
\hline
\end{tabular}

\section{Cooper 1996}

Methods $\quad \mathrm{RCT}, \mathrm{DB}, 4$ parallel groups, single oral dose

Medication administered when baseline pain was of moderate to severe intensity

Pain assessed at $0,15,30,60$ mins then hourly to 6 hours

\begin{tabular}{ll}
\hline Participants & Third molar extraction \\
$\mathrm{N}=70$ & $\mathrm{M}=27, \mathrm{~F}=43$ \\
& Mean age 24 years \\
\hline Interventions & Diclofenac $\mathrm{Na} 50 \mathrm{mg}, \mathrm{n}=18$ \\
& Misoprostol $200 \mu \mathrm{\mu g}, \mathrm{n}=21$ \\
& Diclofenac $\mathrm{Na}+$ misoprostol $50 \mathrm{mg} / 200 \mu \mathrm{g}, \mathrm{n}=20$ \\
& Placebo, $\mathrm{n}=11$ \\
\hline Outcomes & Pl: std 4 point scale \\
& PR: std 5 point scale \\
& Time to use of rescue medication \\
& Numbers with serious adverse events \\
\hline Notes & Oxford Quality Score: R1, DB2, wo \\
Rescue medication permitted after 2 hours. No details of drug used
\end{tabular}

\section{Risk of bias}

\section{Bias}

Authors' judgement Support for judgement 
Cooper 1996 (Continued)

Random sequence genera- Unclear risk Not stated specifically for a second pilot study, but randomised specifically tion (selection bias) stated for first pilot study (on ibuprofen). In our judgement, it is likely that this was randomised

\begin{tabular}{|c|c|c|}
\hline $\begin{array}{l}\text { Allocation concealment } \\
\text { (selection bias) }\end{array}$ & Unclear risk & Not reported \\
\hline $\begin{array}{l}\text { Blinding of participants } \\
\text { and personnel (perfor- } \\
\text { mance bias) } \\
\text { All outcomes }\end{array}$ & Unclear risk & $\begin{array}{l}\text { Not stated specifically for a second pilot study, but randomised specifically } \\
\text { stated for first pilot study (on ibuprofen). In our judgement, it is likely that this } \\
\text { was double-blind }\end{array}$ \\
\hline Size & High risk & $<50$ participants in relevant treatment arms \\
\hline
\end{tabular}

\section{Desjardins 2004}

\begin{tabular}{ll} 
Methods & RCT, DB, 3 parallel groups, single and multiple oral dose phases \\
& Medication administered when baseline pain was of moderate to severe intensity \\
& Pain assessed at $0,15,30,45,60,90,120$ mins, then hourly to 6 hours, and at $8,10,12,14$, and 24 hours \\
\hline Participants & First metatarsal bunionectomy \\
& $\mathrm{N}=252$ \\
$\mathrm{M}=34, \mathrm{~F}=218$ & $\mathrm{Mean}$ age 41 years
\end{tabular}

\begin{tabular}{ll} 
Interventions & Diclofenac $\mathrm{Na}$ (enteric coated) $100 \mathrm{mg}, \mathrm{n}=85$ \\
& Rofecoxib $50 \mathrm{mg}, \mathrm{n}=85$ \\
& Placebo, $\mathrm{n}=82$ \\
\hline
\end{tabular}

PI: std 4 point scale and VAS
PR: std 5 point scale
PGE: std 5 point scale
Numbers using rescue medication
Time to use of rescue medication
Numbers with any adverse event and serious adverse events
Withdrawals

Notes

Oxford Quality Score: R2, DB2, W1

Rescue medication permitted after 90 mins (hydrocodone/paracetamol 7.5/500 mg)

\section{Risk of bias}


Desjardins 2004 (Continued)

Random sequence genera- Low risk $\quad$ "computer generated allocation schedule"
tion (selection bias)

\begin{tabular}{lll}
\hline $\begin{array}{l}\text { Allocation concealment } \\
\text { (selection bias) }\end{array}$ & Unclear risk & Not reported \\
\hline $\begin{array}{l}\text { Blinding of participants } \\
\text { and personnel (perfor- } \\
\text { mance bias) }\end{array}$ & Low risk & "double-dummy technique with matching placebos" \\
All outcomes & &
\end{tabular}

Size $\quad$ Unclear risk $\quad>50$ but $<200$ participants in treatment groups

\section{Herbertson 1995}

Methods $\quad$ RCT, DB, 4 parallel groups, single oral dose

Medication administered when baseline pain was of moderate to severe intensity

Pain assessed at 0,30 , and 60 mins then hourly to 8 hours

\begin{tabular}{|c|c|c|}
\hline \multirow[t]{4}{*}{ Participants } & \multicolumn{2}{|l|}{ Gynaecological surgery } \\
\hline & \multicolumn{2}{|l|}{$N=217$} \\
\hline & \multicolumn{2}{|l|}{ All $F$} \\
\hline & \multicolumn{2}{|l|}{ Mean age 43 years } \\
\hline \multirow[t]{4}{*}{ Interventions } & \multicolumn{2}{|c|}{ Diclofenac K 50 mg, n = 52} \\
\hline & \multicolumn{2}{|c|}{ Diclofenac K $100 \mathrm{mg}, \mathrm{n}=52$} \\
\hline & \multicolumn{2}{|l|}{ Aspirin $650 \mathrm{mg}, \mathrm{n}=53$} \\
\hline & \multicolumn{2}{|l|}{ Placebo, $n=52$} \\
\hline \multirow[t]{3}{*}{ Outcomes } & \multicolumn{2}{|l|}{ PI: std 4 point scale } \\
\hline & \multicolumn{2}{|l|}{ PR: std 5 point scale } \\
\hline & \multicolumn{2}{|l|}{ PGE: std 5 point scale } \\
\hline \multirow[t]{2}{*}{ Notes } & \multicolumn{2}{|c|}{ Oxford Quality Score: R1, DB1, W1 } \\
\hline & \multicolumn{2}{|c|}{ Rescue medication permitted after 1 hour, but 2 hours recommended. No details of drug used } \\
\hline \multicolumn{3}{|l|}{ Risk of bias } \\
\hline Bias & Authors' judgement & Support for judgement \\
\hline $\begin{array}{l}\text { Random sequence genera- } \\
\text { tion (selection bias) }\end{array}$ & Unclear risk & Not reported \\
\hline $\begin{array}{l}\text { Allocation concealment } \\
\text { (selection bias) }\end{array}$ & Unclear risk & Not reported \\
\hline
\end{tabular}




\section{Herbertson 1995 (Continued)}

Blinding of participants $\quad$ Unclear risk Not reported
and personnel (perfor-
mance bias)
All outcomes

Size $\quad$ Unclear risk $\quad>50$ but $<200$ participants in treatment groups

\section{Hersh 2004}

Methods $\quad$ RCT, DB, double-dummy, 4 parallel groups, single oral dose

Medication administered when baseline pain was of moderate to severe intensity

Pain assessed at $0,15,30,45,60,90,120$ mins then hourly to 6 hours

\begin{tabular}{|c|c|}
\hline Participants & $\begin{array}{l}\text { Third molar extraction } \\
N=265 \\
M=111, F=154 \\
\text { Mean age } 21 \text { years }\end{array}$ \\
\hline Interventions & $\begin{array}{l}\text { Diclofenac K } 25 \text { mg, n = 63 } \\
\text { Diclofenac K } 50 \text { mg, n = 68 } \\
\text { Diclofenac K } 100 \text { mg, n = 66 } \\
\text { Placebo, n = } 68\end{array}$ \\
\hline Outcomes & $\begin{array}{l}\text { PI: std } 4 \text { point scale } \\
\text { PR: std } 5 \text { point scale } \\
\text { PGE: std } 5 \text { point scale } \\
\text { Numbers using rescue medication } \\
\text { Time to use of rescue medication } \\
\text { Numbers with any adverse event } \\
\text { Withdrawals }\end{array}$ \\
\hline
\end{tabular}

Notes Oxford Quality Score: R2, DB2, W1

Rescue medication permitted after 1 hour (hydrocodone/paracetamol 5/500 mg or oxycodone/paracetamol $5 / 325 \mathrm{mg}$ )

\begin{tabular}{lll}
\hline Risk of bias & \\
\hline Bias & Authors' judgement & Support for judgement \\
\hline $\begin{array}{l}\text { Random sequence genera- } \\
\text { tion (selection bias) }\end{array}$ & Low risk & "computer-generated random number table" \\
\hline $\begin{array}{l}\text { Allocation concealment } \\
\text { (selection bias) }\end{array}$ & Unclear risk & Not reported \\
\hline
\end{tabular}


Hersh 2004 (Continued)
Blinding of participants
Low risk
"double-blind, double-dummy", "identical appearance" and personnel (performance bias)

All outcomes

\begin{tabular}{ll}
\hline Size $\quad$ Unclear risk $\quad>50$ but $<200$ participants in treatment groups \\
\hline
\end{tabular}

\section{Hofele 2006}

Methods $\quad$ RCT, DB, double-dummy, 3 parallel groups, single oral dose

Medication administered when baseline pain was of moderate to severe intensity

Pain assessed at $0,15,30,45,60,90,120$ mins, then hourly to 6 hours, and at 8 and 24 hours

\begin{tabular}{|c|c|c|}
\hline \multirow[t]{4}{*}{ Participants } & \multicolumn{2}{|l|}{ Third molar extraction } \\
\hline & \multicolumn{2}{|l|}{$N=184$} \\
\hline & \multicolumn{2}{|l|}{$M=85, F=99$} \\
\hline & \multicolumn{2}{|l|}{ Mean age 27 years } \\
\hline \multirow[t]{3}{*}{ Interventions } & \multicolumn{2}{|c|}{ Diclofenac $\mathrm{K}$ sachet $50 \mathrm{mg}$ (fast-acting), $\mathrm{n}=74$} \\
\hline & \multicolumn{2}{|c|}{ Diclofenac $\mathrm{K}$ tablet $50 \mathrm{mg}, \mathrm{n}=71$} \\
\hline & \multicolumn{2}{|l|}{ Placebo, $n=39$} \\
\hline \multirow[t]{7}{*}{ Outcomes } & \multicolumn{2}{|l|}{ PI: std 4 point scale } \\
\hline & \multicolumn{2}{|l|}{ PR: std 5 point scale } \\
\hline & \multicolumn{2}{|l|}{ PGE: std 5 point scale } \\
\hline & \multicolumn{2}{|c|}{ Numbers using rescue medication } \\
\hline & \multicolumn{2}{|c|}{ Time to use of rescue medication } \\
\hline & \multicolumn{2}{|c|}{ Numbers with any adverse event } \\
\hline & \multicolumn{2}{|l|}{ Withdrawals } \\
\hline \multirow[t]{2}{*}{ Notes } & \multicolumn{2}{|c|}{ Oxford Quality Score: R2, DB2, W1 } \\
\hline & \multicolumn{2}{|c|}{ Rescue medication permitted after 2 hours (paracetamol 1000 mg) } \\
\hline \multicolumn{3}{|l|}{ Risk of bias } \\
\hline Bias & Authors' judgement & Support for judgement \\
\hline $\begin{array}{l}\text { Random sequence genera- } \\
\text { tion (selection bias) }\end{array}$ & Low risk & Randomisation scheme prepared by Novartis Pharma AG \\
\hline $\begin{array}{l}\text { Allocation concealment } \\
\text { (selection bias) }\end{array}$ & Unclear risk & Not reported \\
\hline
\end{tabular}


Hofele 2006 (Continued)

Blinding of participants Unclear risk "double-blind, double-dummy"
and personnel (perfor-
mance bias)
All outcomes

\begin{tabular}{ll}
\hline Size $\quad$ Unclear risk $\quad>50$ but $<200$ participants in treatment groups \\
\hline
\end{tabular}

\section{Kubitzek 2003}

\begin{tabular}{ll}
\hline Methods & RCT, DB, 3 parallel groups, single oral dose \\
& Medication administered when baseline pain was of moderate to severe intensity \\
& Pain assessed at $0,30,60$ mins then hourly to 6 hours
\end{tabular}

\begin{tabular}{ll}
\hline Participants & Third molar extraction \\
& $\mathrm{N}=245$ \\
$\mathrm{M}=\sim 40 \%, \mathrm{~F}=\sim 60 \%$ \\
& Age not given \\
\hline Interventions & Diclofenac $\mathrm{K} 25 \mathrm{mg}, \mathrm{n}=83$ \\
& Paracetamol $1000 \mathrm{mg}, \mathrm{n}=78$ \\
& Placebo, $\mathrm{n}=84$
\end{tabular}

PI: std 4 point scale
PR: std 5 point scale
PGE: std 5 point scale
Numbers using rescue medication
Time to use of rescue medication
Numbers with any adverse event and serious adverse events
Withdrawals

Notes Oxford Quality Score: R1, DB2, W1

Rescue medication permitted after 1 hour (ibuprofen 200 mg)

\section{Risk of bias}

\section{Bias}

Authors' judgement Support for judgement

Random sequence genera- Unclear risk $\quad$ Not reported
tion (selection bias)

Allocation concealment $\quad$ Unclear risk $\quad$ Not reported
(selection bias)


Kubitzek 2003 (Continued)

Blinding of participants Low risk "double-blind, double-dummy" and personnel (performance bias)

All outcomes

Size Unclear risk $\quad>50$ but $<200$ participants in treatment groups

\section{Manvelian 2012a}

Methods $\quad$ RCT, DB, 4 parallel groups, single oral dose

Medication administered when baseline pain was of moderate to severe intensity

Pain assessed at $0,15,30,45,60,90$, and 120 mins, then hourly to 8 hours, then 10 and 12 hours

\begin{tabular}{|c|c|c|}
\hline \multirow[t]{4}{*}{ Participants } & \multicolumn{2}{|l|}{ Third molar extraction } \\
\hline & \multicolumn{2}{|l|}{$N=202$} \\
\hline & \multicolumn{2}{|l|}{$M=43 \%, F=57 \%$} \\
\hline & \multicolumn{2}{|l|}{ Mean age 22 years } \\
\hline \multirow[t]{4}{*}{ Interventions } & \multicolumn{2}{|c|}{ Diclofenac $\mathrm{K}$ nanoparticle $18 \mathrm{mg}, \mathrm{n}=49$} \\
\hline & \multicolumn{2}{|c|}{ Diclofenac K nanoparticle 36 mg, n = 51} \\
\hline & \multicolumn{2}{|c|}{ Celecoxib $400 \mathrm{mg}, \mathrm{n}=51$} \\
\hline & \multicolumn{2}{|l|}{ Placebo, $\mathrm{n}=51$} \\
\hline \multirow[t]{2}{*}{ Outcomes } & \multicolumn{2}{|l|}{ VAS PI and PR } \\
\hline & \multicolumn{2}{|l|}{ Adverse events } \\
\hline \multirow[t]{2}{*}{ Notes } & \multirow{2}{*}{\multicolumn{2}{|c|}{$\begin{array}{l}\text { Oxford Quality Score: R1, DB1, W1 } \\
\text { Rescue medication permitted after } 1 \text { hour (ibuprofen } 200 \text { mg) }\end{array}$}} \\
\hline & & \\
\hline \multicolumn{3}{|l|}{ Risk of bias } \\
\hline Bias & Authors' judgement & Support for judgement \\
\hline $\begin{array}{l}\text { Random sequence genera- } \\
\text { tion (selection bias) }\end{array}$ & Unclear risk & Not reported \\
\hline $\begin{array}{l}\text { Allocation concealment } \\
\text { (selection bias) }\end{array}$ & Unclear risk & Not reported \\
\hline $\begin{array}{l}\text { Blinding of participants } \\
\text { and personnel (perfor- } \\
\text { mance bias) } \\
\text { All outcomes }\end{array}$ & Unclear risk & Not reported \\
\hline Size & Unclear risk & $>50$ but $<200$ participants in treatment groups \\
\hline
\end{tabular}


Mehlisch 1995

\begin{tabular}{|c|c|}
\hline Methods & $\begin{array}{l}\text { RCT, DB, double-dummy, } 4 \text { parallel groups, single oral dose } \\
\text { Medication administered when baseline pain was of moderate to severe intensity } \\
\text { Pain assessed at } 0,30,60 \text { mins then hourly to } 8 \text { hours }\end{array}$ \\
\hline Participants & $\begin{array}{l}\text { Third molar extraction } \\
N=208 \\
M=91, F=117 \\
\text { Mean age } 26 \text { years }\end{array}$ \\
\hline Interventions & $\begin{array}{l}\text { Diclofenac K } 50 \text { mg, n = 53 } \\
\text { Diclofenac K } 100 \text { mg, n= } 52 \\
\text { Aspirin } 650 \text { mg, n = 51 } \\
\text { Placebo, } n=52\end{array}$ \\
\hline Outcomes & $\begin{array}{l}\text { PI: std } 4 \text { point scale } \\
\text { PR: std } 5 \text { point scale } \\
\text { PGE: std } 5 \text { point scale } \\
\text { Numbers using rescue medication } \\
\text { Time to use of rescue medication } \\
\text { Numbers with any adverse event and serious adverse events } \\
\text { Withdrawals }\end{array}$ \\
\hline Notes & $\begin{array}{l}\text { Oxford Quality Score: R1, DB2, W1 } \\
\text { Rescue medication permitted after } 2 \text { hours. No details of drug used }\end{array}$ \\
\hline
\end{tabular}

\section{Risk of bias}

\begin{tabular}{lll}
\hline Bias & Authors' judgement & Support for judgement \\
\hline $\begin{array}{l}\text { Random sequence genera- } \\
\text { tion (selection bias) }\end{array}$ & Unclear risk & Not reported \\
\hline $\begin{array}{l}\text { Allocation concealment } \\
\text { (selection bias) }\end{array}$ & Unclear risk & Not reported \\
\hline $\begin{array}{l}\text { Blinding of participants } \\
\text { and personnel (perfor- } \\
\text { mance bias) } \\
\text { All outcomes }\end{array}$ & Low risk & Double-dummy \\
\hline Size & & \\
\hline
\end{tabular}


Nelson 1994

\begin{tabular}{|c|c|}
\hline Methods & $\begin{array}{l}\text { RCT, DB, } 5 \text { parallel groups, single oral dose } \\
\text { Medication administered when baseline pain was of moderate to severe intensity } \\
\text { Pain assessed at } 0,15,30,45,60,90,120 \text { mins then hourly to } 6 \text { hours }\end{array}$ \\
\hline Participants & $\begin{array}{l}\text { Third molar extraction } \\
N=183 \\
M=126, F=129 \\
\text { Mean age } 25 \text { years }\end{array}$ \\
\hline Interventions & $\begin{array}{l}\text { Diclofenac K } 25 \text { mg, } n=50 \\
\text { Diclofenac K } 50 \text { mg, } n=50 \\
\text { Diclofenac K } 100 \text { mg, } n=50 \\
\text { Aspirin } 650 \mathrm{mg}, \mathrm{n}=50 \\
\text { Placebo, } \mathrm{n}=50\end{array}$ \\
\hline Outcomes & $\begin{array}{l}\text { PI: std } 4 \text { point scale } \\
\text { PR: std } 5 \text { point scale } \\
\text { PGE: std } 5 \text { point scale } \\
\text { Numbers using rescue medication } \\
\text { Time to use of rescue medication } \\
\text { Numbers with any adverse event } \\
\text { Withdrawals due to adverse events }\end{array}$ \\
\hline
\end{tabular}

Notes

Oxford Quality Score: R1, DB2, W1

Rescue medication permitted after 1 hour. No details of drug used

\section{Risk of bias}

\begin{tabular}{lll}
\hline Bias & Authors' judgement & Support for judgement \\
\hline $\begin{array}{l}\text { Random sequence genera- } \\
\text { tion (selection bias) }\end{array}$ & Unclear risk & Not reported \\
\hline $\begin{array}{l}\text { Allocation concealment } \\
\text { (selection bias) }\end{array}$ & Unclear risk & Not reported \\
\hline $\begin{array}{l}\text { Blinding of participants } \\
\text { and personnel (perfor- } \\
\text { mance bias) }\end{array}$ & Unclear risk & "matching placebo identical in appearance" \\
All outcomes & &
\end{tabular}

\begin{tabular}{ll}
\hline Size $\quad$ High risk & 50 participants in treatment groups \\
\hline
\end{tabular}


Olson 1997

\begin{tabular}{|c|c|}
\hline Methods & $\begin{array}{l}\text { RCT, DB, } 5 \text { parallel groups, single oral dose } \\
\text { Medication administered when baseline pain was of moderate to severe intensity } \\
\text { Pain assessed at } 0,30,60 \text { mins then hourly to } 8 \text { hours }\end{array}$ \\
\hline Participants & $\begin{array}{l}\text { Post-episiotomy } \\
\mathrm{N}=255 \\
\text { All F } \\
\text { Mean age } 24 \text { years }\end{array}$ \\
\hline Interventions & $\begin{array}{l}\text { Diclofenac K } 25 \text { mg, n = 52 } \\
\text { Diclofenac K } 50 \text { mg, n = 50 } \\
\text { Diclofenac K } 100 \text { mg, } n=51 \\
\text { Aspirin } 650 \text { mg, } n=50 \\
\text { Placebo, } n=52\end{array}$ \\
\hline Outcomes & $\begin{array}{l}\text { PI: std } 4 \text { point scale } \\
\text { PR: std } 5 \text { point scale } \\
\text { PGE: non std } 4 \text { point scale } \\
\text { Numbers using rescue medication } \\
\text { Time to use of rescue medication } \\
\text { Numbers with any adverse event and serious adverse events } \\
\text { Withdrawals }\end{array}$ \\
\hline
\end{tabular}

Notes

Oxford Quality Score: R1, DB2, W1

Rescue medication permitted after 1 hour (non-study analgesic)

\section{Risk of bias}

\section{Bias}

\section{Authors' judgement Support for judgement}

Random sequence genera- Low risk "computer program generated a random number permutation"
tion (selection bias)

\begin{tabular}{|c|c|c|}
\hline $\begin{array}{l}\text { Allocation concealment } \\
\text { (selection bias) }\end{array}$ & Unclear risk & Not reported \\
\hline $\begin{array}{l}\text { Blinding of participants } \\
\text { and personnel (perfor- } \\
\text { mance bias) } \\
\text { All outcomes }\end{array}$ & Low risk & "matching placebo" \\
\hline Size & Unclear risk & 50 or more participants in relevant treatment groups \\
\hline
\end{tabular}


Riff 2009

\begin{tabular}{|c|c|}
\hline Methods & $\begin{array}{l}\text { R, DB, } 4 \text { parallel groups, single oral dose } \\
\text { Medication administered when baseline pain was of moderate to severe intensity } \\
\text { Pain assessed at } 0,10,15,20,30,45,60,90,120 \text { mins then hourly to } 8 \text { hours }\end{array}$ \\
\hline Participants & $\begin{array}{l}\text { Day after bunionectomy (fasted until } 1.5 \text { hours after dose) } \\
N=201 \\
M=27, F=174 \\
\text { Mean age } 45 \text { years }\end{array}$ \\
\hline Interventions & $\begin{array}{l}\text { Diclofenac } \mathrm{K} \text { softgel } 25 \mathrm{mg}, \mathrm{n}=102 \\
\text { Placebo, } \mathrm{n}=99 \\
\text { Note: second dose permitted if pain relief insufficient after } 1 \text { hour }\end{array}$ \\
\hline Outcomes & $\begin{array}{l}\text { PI: std } 4 \text { point scale } \\
\text { PR: std } 5 \text { point scale } \\
\text { PGE: std } 5 \text { point scale } \\
\text { Numbers using rescue medication } \\
\text { Time to use of rescue medication } \\
\text { Numbers with any adverse event and serious adverse events } \\
\text { Withdrawals }\end{array}$ \\
\hline
\end{tabular}

\section{Notes}

Oxford Quality Score: R2, DB1, W1

Rescue medication permitted after 1 hour

\section{Risk of bias}

\begin{tabular}{lll}
\hline Bias & Authors' judgement & Support for judgement \\
\hline $\begin{array}{l}\text { Random sequence genera- } \\
\text { tion (selection bias) }\end{array}$ & Unclear risk & Pre-randomised by sponsor \\
\hline $\begin{array}{l}\text { Allocation concealment } \\
\text { (selection bias) }\end{array}$ & Unclear risk & Not reported \\
\hline $\begin{array}{l}\text { Blinding of participants } \\
\text { and personnel (perfor- } \\
\text { mance bias) } \\
\text { All outcomes }\end{array}$ & Unclear risk & Not reported \\
\hline Size & & \\
\hline
\end{tabular}

\section{Torres 2004}

Methods

RCT, DB, 4 parallel groups, single and multiple dose phases 
Torres 2004 (Continued)

Medication administered when baseline pain was of moderate to severe intensity

Pain assessed at $0,30,45,60$ mins, then hourly to 6 hours, then at 10,12, 18, 24, 36 hours

\begin{tabular}{|c|c|c|}
\hline \multirow[t]{4}{*}{ Participants } & \multicolumn{2}{|l|}{ Inguinal hernia surgery } \\
\hline & \multicolumn{2}{|l|}{$N=269$} \\
\hline & \multicolumn{2}{|l|}{ All $\mathrm{M}$} \\
\hline & \multicolumn{2}{|l|}{ Mean age 53 years } \\
\hline \multirow[t]{4}{*}{ Interventions } & \multicolumn{2}{|c|}{ Diclofenac SR 75 mg, $n=68$} \\
\hline & \multicolumn{2}{|c|}{ Valdecoxib $20 \mathrm{mg}, \mathrm{n}=68$} \\
\hline & \multicolumn{2}{|c|}{ Valdecoxib 40 mg, n = 69} \\
\hline & \multicolumn{2}{|l|}{ Placebo, $\mathrm{n}=67$} \\
\hline \multirow[t]{6}{*}{ Outcomes } & \multicolumn{2}{|c|}{ PI: std 4 point scale and VAS } \\
\hline & \multicolumn{2}{|c|}{ PGE: non std 4 point scale } \\
\hline & \multicolumn{2}{|c|}{ Numbers using rescue medication } \\
\hline & \multicolumn{2}{|c|}{ Time to use of rescue medication } \\
\hline & \multicolumn{2}{|c|}{ Numbers with any adverse event } \\
\hline & \multicolumn{2}{|l|}{ Withdrawals } \\
\hline \multirow[t]{2}{*}{ Notes } & \multicolumn{2}{|c|}{ Oxford Quality Score: R1, DB1, W1 } \\
\hline & \multicolumn{2}{|c|}{ Rescue medication permitted at any time (usual analgesic for hospital) } \\
\hline \multicolumn{3}{|l|}{ Risk of bias } \\
\hline Bias & Authors' judgement & Support for judgement \\
\hline $\begin{array}{l}\text { Random sequence genera- } \\
\text { tion (selection bias) }\end{array}$ & Unclear risk & Not reported \\
\hline $\begin{array}{l}\text { Allocation concealment } \\
\text { (selection bias) }\end{array}$ & Unclear risk & Not reported \\
\hline $\begin{array}{l}\text { Blinding of participants } \\
\text { and personnel (perfor- } \\
\text { mance bias) } \\
\text { All outcomes }\end{array}$ & Unclear risk & Not reported \\
\hline Size & Unclear risk & $>50$ but $<200$ participants in treatment groups \\
\hline
\end{tabular}

Zuniga 2004

Methods $\quad$ R, DB, 3 parallel groups, single oral dose

Medication administered when baseline pain was of moderate to severe intensity 
Zuniga 2004 (Continued)

Pain assessed at $0,15,30,45,60,90,120$ mins, then hourly to 6 hours, then at 8 and 24 hours

\begin{tabular}{|c|c|c|}
\hline Participants & \multicolumn{2}{|l|}{$\begin{array}{l}\text { Third molar extraction } \\
\mathrm{N}=75 \\
\mathrm{M}=25, \mathrm{~F}=50 \\
\text { Mean age } 23 \text { years }\end{array}$} \\
\hline Outcomes & $\begin{array}{l}\text { PI: std } 4 \text { point scale } \\
\text { PR: std } 5 \text { point scale } \\
\text { PGE: std } 5 \text { point scale } \\
\text { Numbers using rescue } \\
\text { Time to use of rescue } \\
\text { Numbers with any adv } \\
\text { Withdrawals }\end{array}$ & $\begin{array}{l}\text { nedication } \\
\text { edication } \\
\text { rse event and serious adverse events }\end{array}$ \\
\hline Notes & \multicolumn{2}{|c|}{$\begin{array}{l}\text { Oxford Quality Score: R2, DB2, W1 } \\
\text { Rescue medication permitted at any time. No details of drug used }\end{array}$} \\
\hline $\begin{array}{l}\text { Random sequence genera- } \\
\text { tion (selection bias) }\end{array}$ & Low risk & Random assignment using computer program \\
\hline $\begin{array}{l}\text { Allocation concealment } \\
\text { (selection bias) }\end{array}$ & High risk & "surgeon who dispensed medication not masked to allocation" \\
\hline $\begin{array}{l}\text { Blinding of participants } \\
\text { and personnel (perfor- } \\
\text { mance bias) } \\
\text { All outcomes }\end{array}$ & Unclear risk & "placebo constituted using same packaging as softgel" \\
\hline Size & High risk & $<50$ participants in treatment groups \\
\hline
\end{tabular}

\section{Zuniga 2010}

Methods $\quad$ R, DB, 4 parallel groups, single oral dose

Medication administered when baseline pain was of moderate to severe intensity

Pain assessed at $0,15,30,45,60,90,120$ mins then hourly to 6 hours

Participants Third molar extraction

Single dose oral diclofenac for acute postoperative pain in adults (Review) 
Zuniga 2010 (Continued)

$$
\begin{aligned}
& N=249 \\
& M=115, F=134
\end{aligned}
$$

\begin{tabular}{|c|c|c|}
\hline \multirow[t]{4}{*}{ Interventions } & \multicolumn{2}{|c|}{ Diclofenac $\mathrm{K}$ softgel $25 \mathrm{mg}, \mathrm{n}=63$} \\
\hline & \multicolumn{2}{|c|}{ Diclofenac K softgel 50 mg, $n=62$} \\
\hline & \multicolumn{2}{|c|}{ Diclofenac $K$ softgel 100 mg, $n=63$} \\
\hline & \multicolumn{2}{|l|}{ Placebo, $n=61$} \\
\hline \multirow[t]{7}{*}{ Outcomes } & \multicolumn{2}{|l|}{ PI: std 4 point scale } \\
\hline & \multicolumn{2}{|l|}{ PR: std 5 point scale } \\
\hline & \multicolumn{2}{|l|}{ PGE: std 5 point scale } \\
\hline & \multicolumn{2}{|c|}{ Numbers using rescue medication } \\
\hline & \multicolumn{2}{|c|}{ Time to use of rescue medication } \\
\hline & \multicolumn{2}{|c|}{ Numbers with any adverse event and serious adverse events } \\
\hline & \multicolumn{2}{|l|}{ Withdrawals } \\
\hline \multirow[t]{2}{*}{ Notes } & \multicolumn{2}{|c|}{ Oxford Quality Score: R2, DB1, W1 } \\
\hline & \multicolumn{2}{|c|}{ Rescue medication permitted after 1 hour } \\
\hline \multicolumn{3}{|l|}{ Risk of bias } \\
\hline Bias & Authors' judgement & Support for judgement \\
\hline $\begin{array}{l}\text { Random sequence genera- } \\
\text { tion (selection bias) }\end{array}$ & Unclear risk & Not reported \\
\hline $\begin{array}{l}\text { Allocation concealment } \\
\text { (selection bias) }\end{array}$ & Unclear risk & Not reported \\
\hline $\begin{array}{l}\text { Blinding of participants } \\
\text { and personnel (perfor- } \\
\text { mance bias) } \\
\text { All outcomes }\end{array}$ & Unclear risk & Not reported \\
\hline Size & Unclear risk & $>50$ but $<200$ participants in treatment groups \\
\hline
\end{tabular}

Mean age 24 years

DB: double blind; F: female; M: male; N: total number in trial; n: number in treatment arm; PI: pain intensity; PR: pain relief; PGE: patient global evaluation; SR: slow release; std: standard; R: randomised; W: withdrawals

\section{Characteristics of excluded studies [ordered by study ID]}

\begin{tabular}{ll}
\hline Study & Reason for exclusion \\
\hline Daniels 2012 & Pooled analysis of two previous studies looking at effect of initial pain intensity \\
\hline Zuniga 2011 & Pooled analysis of two previous studies looking at stop-watch time to onset results only \\
\hline
\end{tabular}


Characteristics of ongoing studies [ordered by study ID]

NCT01462435

\begin{tabular}{ll}
\hline Trial name or title & NCT01462435 \\
\hline Methods & $\begin{array}{l}\text { Randomised, double-blind, multiple-dose, parallel-group, active- and placebo-controlled } \\
\text { study }\end{array}$ \\
\hline Participants & Bunionectomy surgery \\
\hline Interventions & Diclofenac, celecoxib, placebo \\
\hline Outcomes & Various pain intensity and relief measures \\
\hline Starting date & October 2011 \\
\hline Contact information & Iroko Pharmaceuticals, LLC \\
\hline Notes & \\
\hline
\end{tabular}

\section{DATA AND ANALYSES}

\section{Comparison 1. Diclofenac fast-acting versus placebo}

\begin{tabular}{lllll}
\hline $\begin{array}{l}\text { Outcome or subgroup } \\
\text { title }\end{array}$ & No. of studies & $\begin{array}{l}\text { No. of partici- } \\
\text { pants }\end{array}$ & Statistical method & Effect size \\
\hline $\begin{array}{l}1 \text { At least 50\% of maxi- } \\
\text { mum pain relief over } \\
\text { hours }\end{array}$ & 6 & & Risk Ratio (M-H, Fixed, 95\% Cl) & Subtotals only \\
\hline $1.125 \mathrm{mg}$ & 2 & 325 & Risk Ratio (M-H, Fixed, 95\% Cl) & $8.73[3.18,23.97]$ \\
\hline $1.250 \mathrm{mg}$ & 4 & Risk Ratio (M-H, Fixed, 95\% Cl) & $2.90[2.23,3.76]$ \\
\hline $1.3100 \mathrm{mg}$ & 2 & 486 & Risk Ratio (M-H, Fixed, 95\% Cl) & $18.09[3.60,90.75]$ \\
\hline $\begin{array}{l}2 \text { Remedication within } 6 \\
\text { or } 8 \text { hours }\end{array}$ & 5 & 168 & Risk Ratio (M-H, Fixed, 95\% Cl) & Subtotals only \\
\hline $2.150 \mathrm{mg}$ & 4 & Risk Ratio (M-H, Fixed, 95\% Cl) & $0.46[0.38,0.56]$ \\
\hline $2.2100 \mathrm{mg}$ & 2 & 486 & Risk Ratio (M-H, Fixed, 95\% Cl) & $0.61[0.48,0.77]$ \\
\hline
\end{tabular}




\section{Analysis 1.1. Comparison 1 Diclofenac fast-acting versus placebo,} Outcome 1 At least 50\% of maximum pain relief over 6 hours.

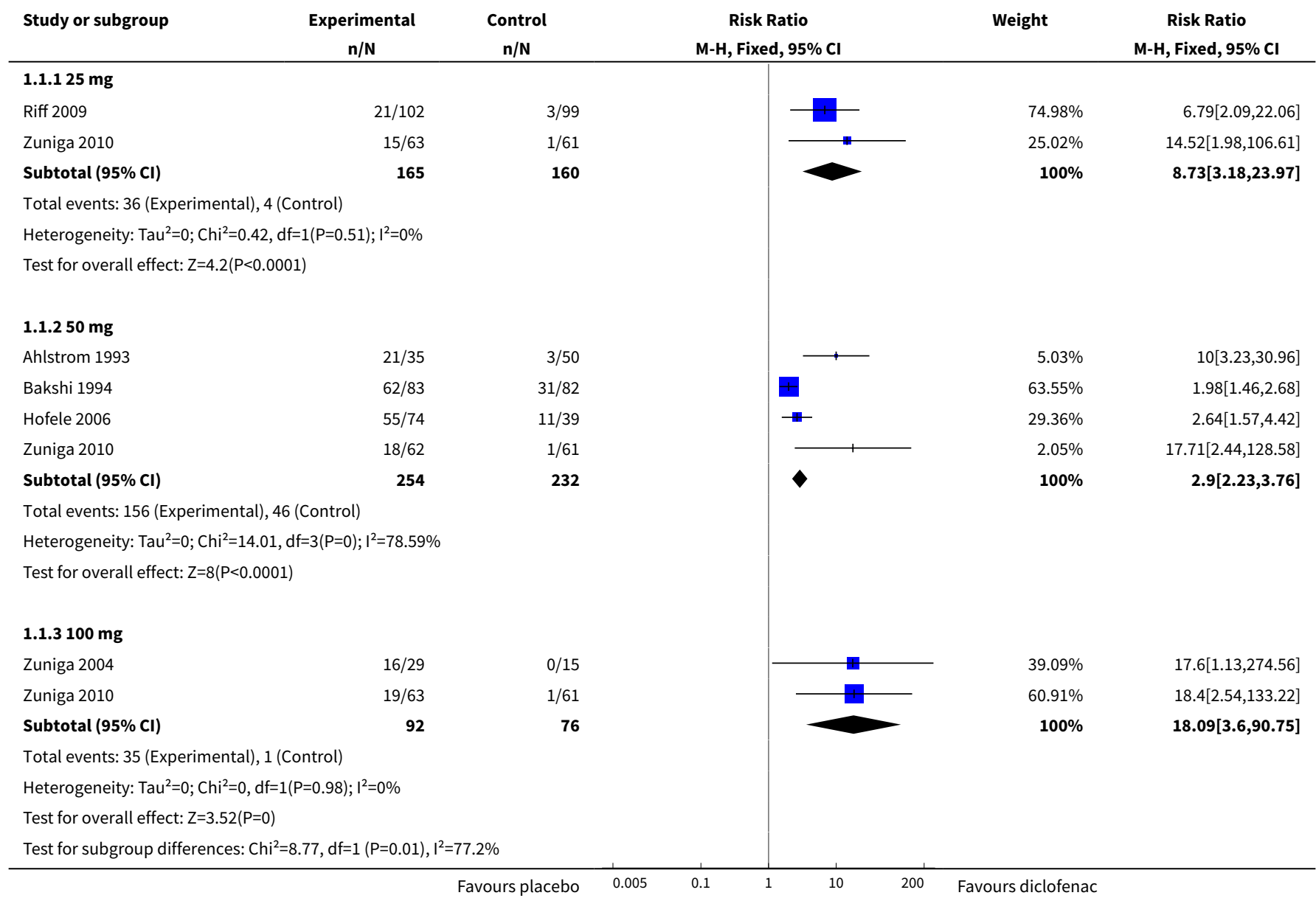

Analysis 1.2. Comparison 1 Diclofenac fast-acting versus placebo, Outcome 2 Remedication within 6 or 8 hours.

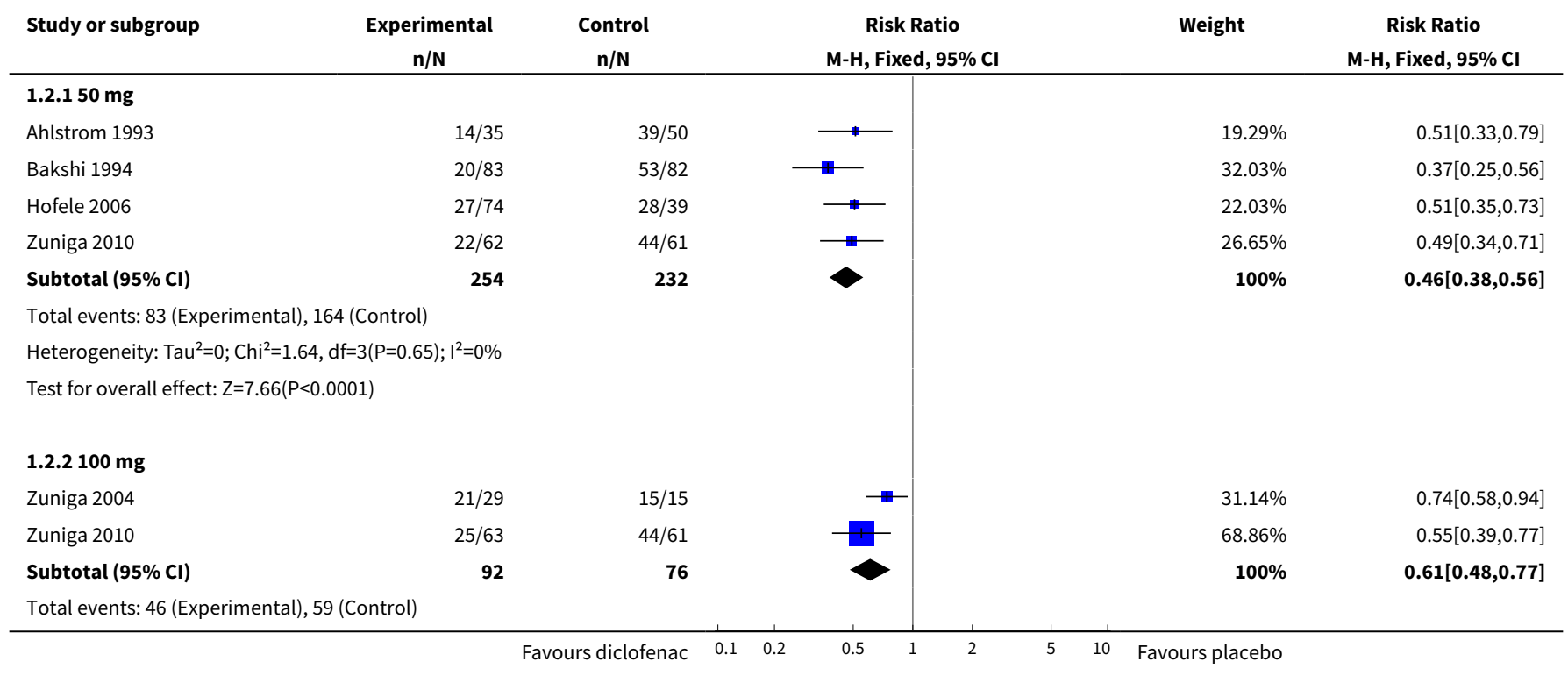




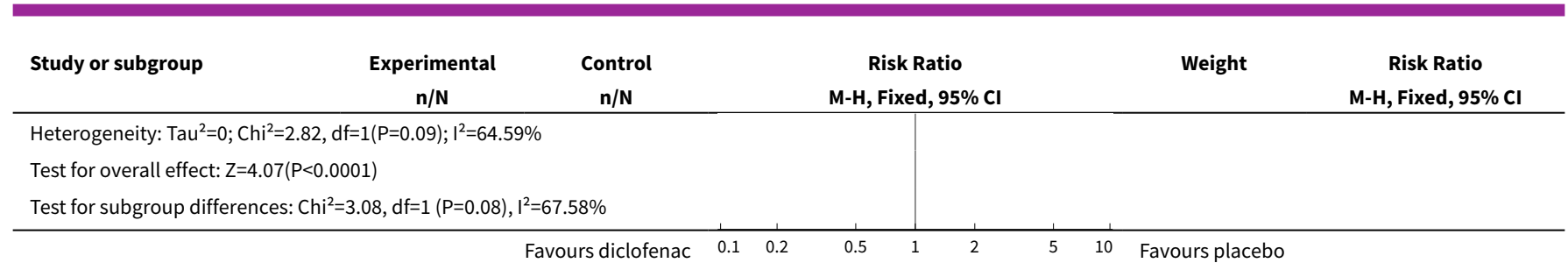

\section{Comparison 2. Diclofenac potassium versus placebo}

\begin{tabular}{|c|c|c|c|c|}
\hline $\begin{array}{l}\text { Outcome or subgroup } \\
\text { title }\end{array}$ & No. of studies & $\begin{array}{l}\text { No. of partici- } \\
\text { pants }\end{array}$ & Statistical method & Effect size \\
\hline $\begin{array}{l}1 \text { At least } 50 \% \text { of maxi- } \\
\text { mum pain relief over } 6 \\
\text { hours }\end{array}$ & 9 & & Risk Ratio (M-H, Fixed, 95\% Cl) & Subtotals only \\
\hline $1.125 \mathrm{mg}$ & 4 & 502 & Risk Ratio (M-H, Fixed, 95\% Cl) & $3.88[2.84,5.32]$ \\
\hline $1.250 \mathrm{mg}$ & 7 & 757 & Risk Ratio (M-H, Fixed, 95\% CI) & $3.68[2.90,4.68]$ \\
\hline $1.3100 \mathrm{mg}$ & 6 & 589 & Risk Ratio (M-H, Fixed, 95\% CI) & $5.05[3.74,6.82]$ \\
\hline $\begin{array}{l}2 \text { Remedication within } 6 \\
\text { or } 8 \text { hours }\end{array}$ & 9 & & Risk Ratio (M-H, Fixed, 95\% Cl) & Subtotals only \\
\hline $2.125 \mathrm{mg}$ & 4 & 502 & Risk Ratio (M-H, Fixed, 95\% Cl) & $0.72[0.63,0.82]$ \\
\hline $2.250 \mathrm{mg}$ & 7 & 757 & Risk Ratio (M-H, Fixed, 95\% Cl) & $0.52[0.45,0.60]$ \\
\hline $2.3100 \mathrm{mg}$ & 6 & 589 & Risk Ratio (M-H, Fixed, 95\% Cl) & $0.45[0.38,0.54]$ \\
\hline
\end{tabular}

\section{Analysis 2.1. Comparison 2 Diclofenac potassium versus placebo, Outcome 1 At least $50 \%$ of maximum pain relief over 6 hours.}

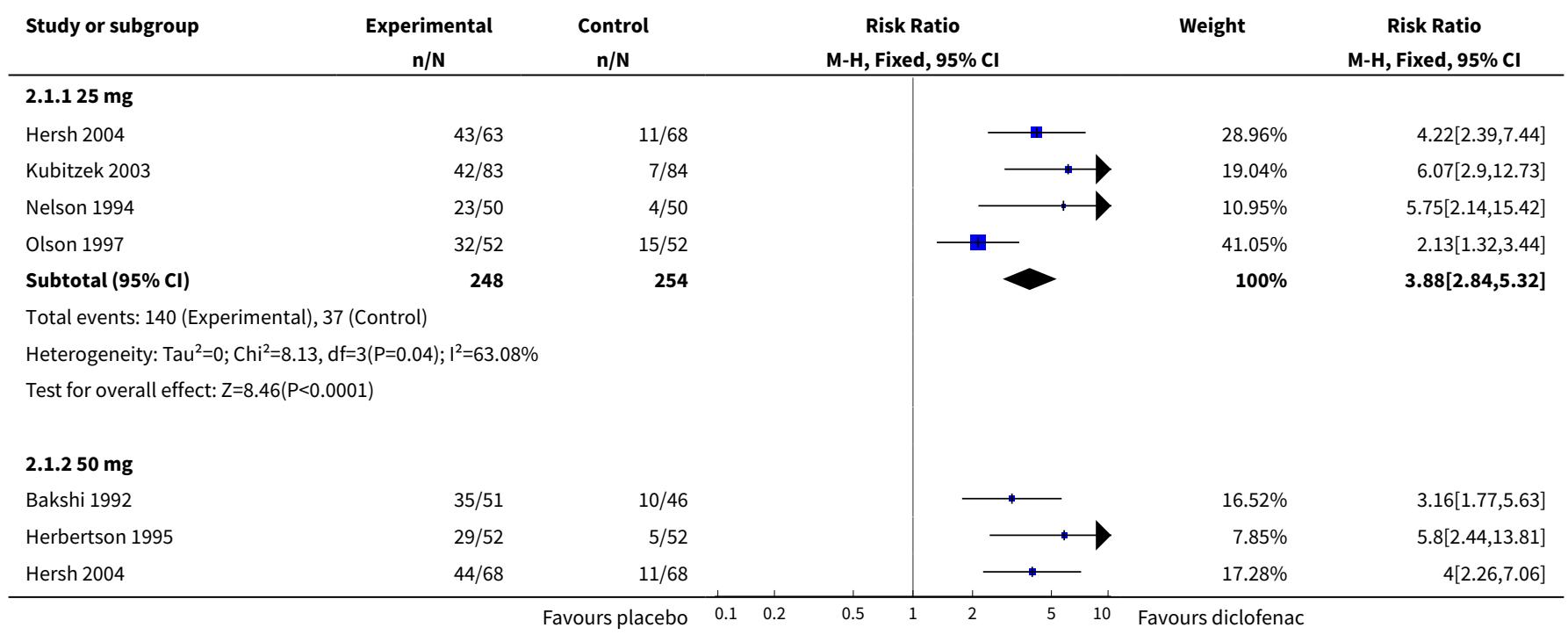




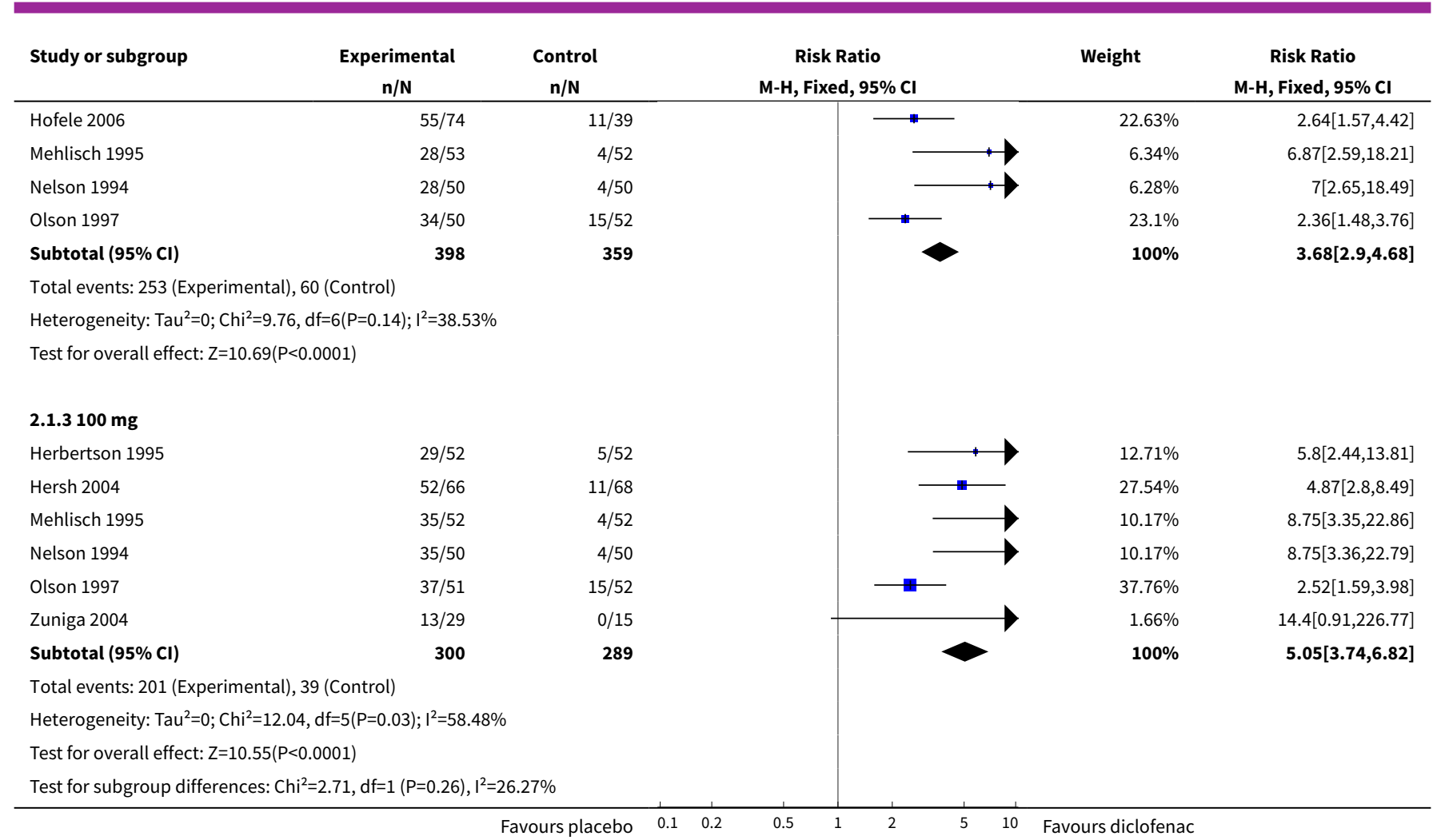

Analysis 2.2. Comparison 2 Diclofenac potassium versus placebo, Outcome 2 Remedication within 6 or 8 hours.

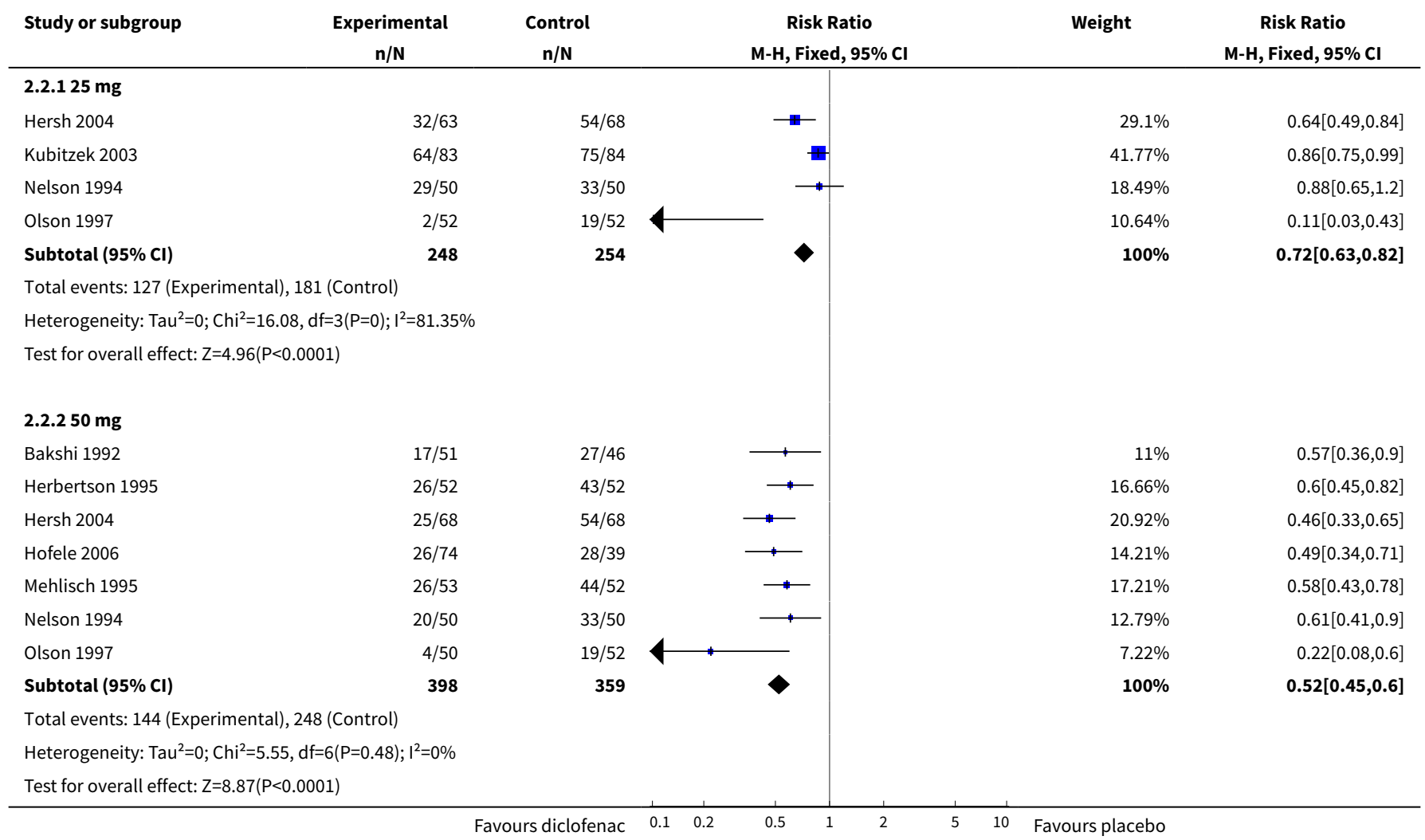




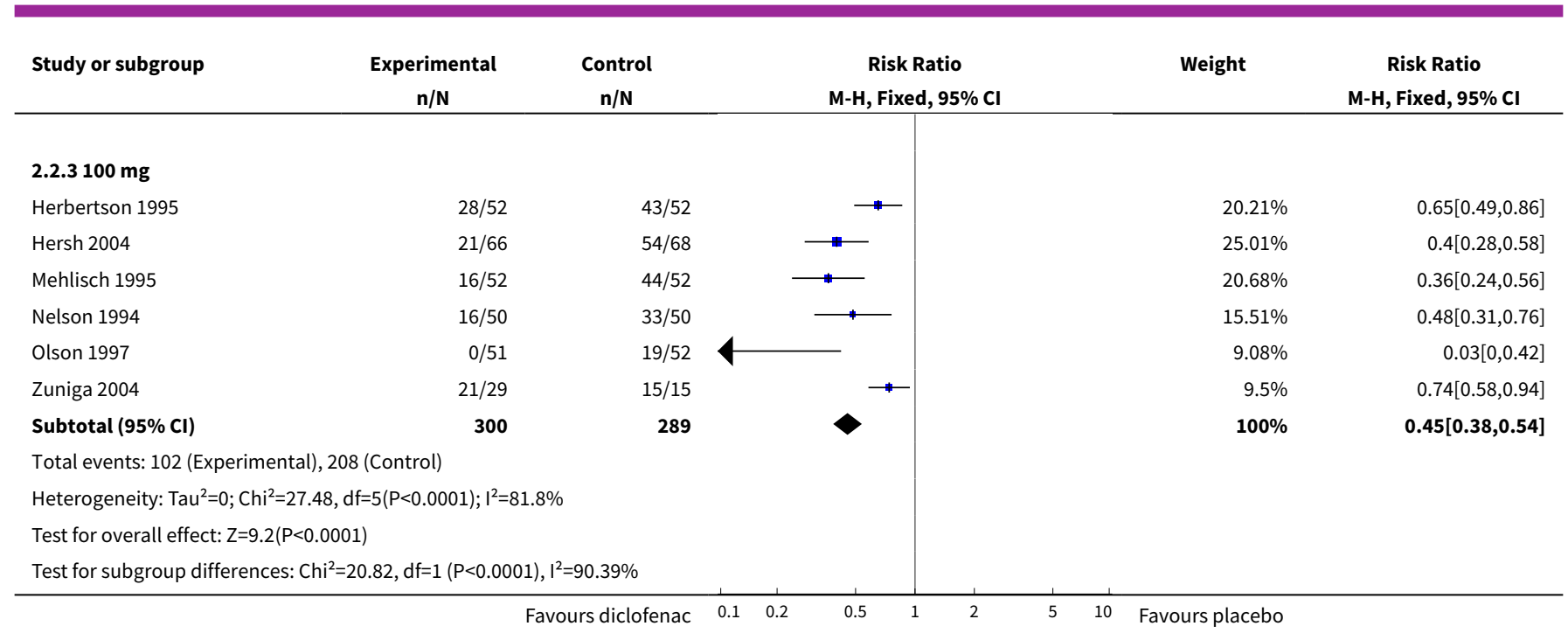

\section{Comparison 3. Diclofenac sodium versus placebo}

\begin{tabular}{lllll}
\hline Outcome or subgroup title & No. of studies & $\begin{array}{l}\text { No. of partici- } \\
\text { pants }\end{array}$ & Statistical method & Effect size \\
\hline $\begin{array}{l}\text { 1 At least 50\% of maximum } \\
\text { pain relief over 6 hours }\end{array}$ & 4 & & Risk Ratio (M-H, Fixed, 95\% Cl) & Subtotals only \\
\hline $1.150 \mathrm{mg}$ & 3 & 313 & Risk Ratio (M-H, Fixed, 95\% Cl) & $2.04[1.26,3.31]$ \\
\hline $\begin{array}{l}1.2100 \mathrm{mg} \\
2 \text { Remedication within 6 or }\end{array}$ & 2 & 167 & Risk Ratio (M-H, Fixed, 95\% Cl) & $3.14[1.07,9.22]$ \\
\hline 8 hours & 1 & Risk Ratio (M-H, Fixed, 95\% Cl) & Subtotals only \\
\hline $2.150 \mathrm{mg}$ & 2 & 284 & Risk Ratio (M-H, Fixed, 95\% Cl) & $0.82[0.69,0.98]$ \\
\hline
\end{tabular}

\section{Analysis 3.1. Comparison 3 Diclofenac sodium versus placebo, Outcome 1 At least $50 \%$ of maximum pain relief over 6 hours.}

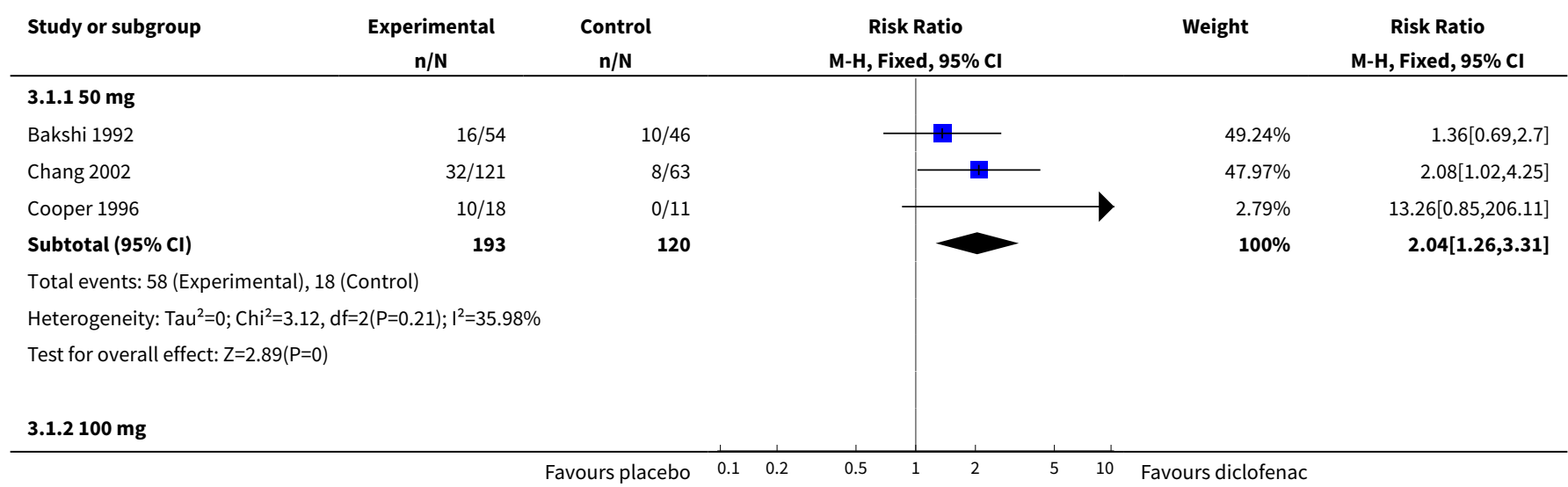




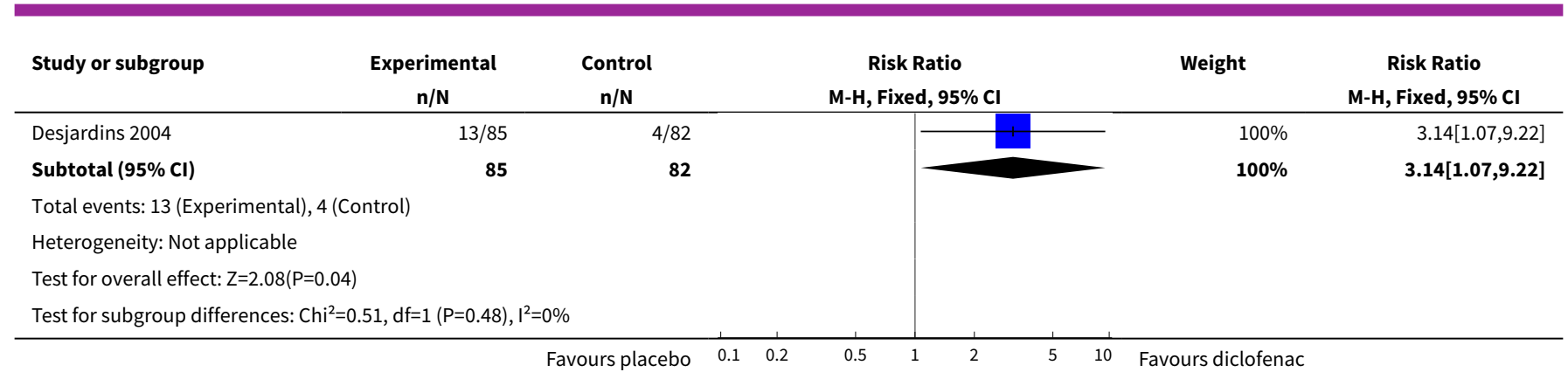

Analysis 3.2. Comparison 3 Diclofenac sodium versus placebo, Outcome 2 Remedication within 6 or 8 hours.

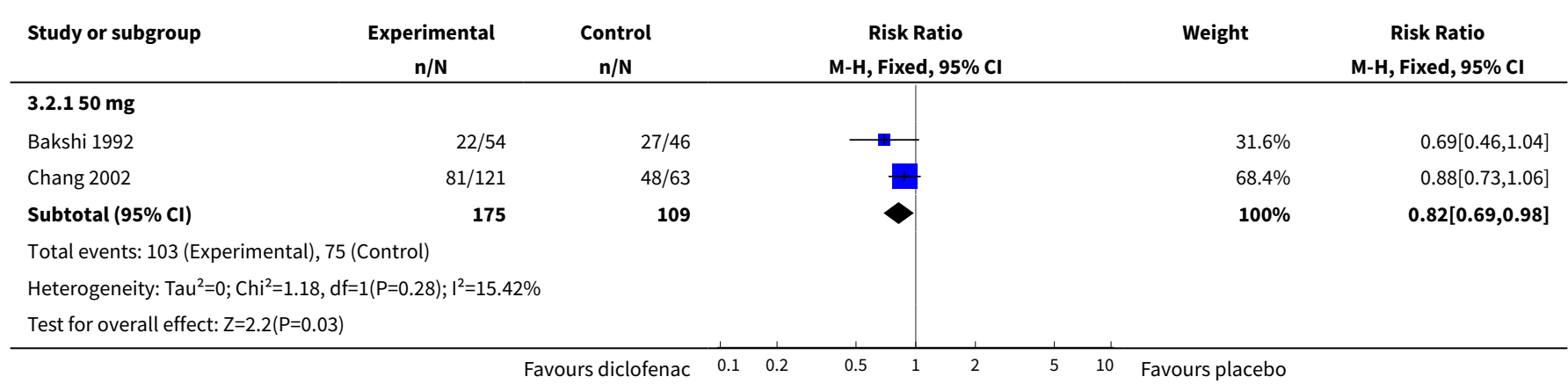

\section{Comparison 4. Adverse events - diclofenac versus placebo}

\begin{tabular}{lllll}
\hline Outcome or subgroup title & No. of studies & $\begin{array}{l}\text { No. of partici- } \\
\text { pants }\end{array}$ & Statistical method & Effect size \\
\hline 1 Adverse events within 24 hours & 10 & & Risk Ratio (M-H, Fixed, 95\% Cl) & Subtotals only \\
\hline $\begin{array}{l}1.1 \text { Fast-acting formulations (all dos- } \\
\text { es) }\end{array}$ & 5 & 636 & Risk Ratio (M-H, Fixed, 95\% Cl) & $1.04[0.60,1.83]$ \\
\hline 1.2 Diclofenac potassium (all doses) & 7 & 1090 & Risk Ratio (M-H, Fixed, 95\% Cl) & $1.03[0.66,1.62]$ \\
\hline
\end{tabular}

Analysis 4.1. Comparison 4 Adverse events - diclofenac versus placebo, Outcome 1 Adverse events within 24 hours.

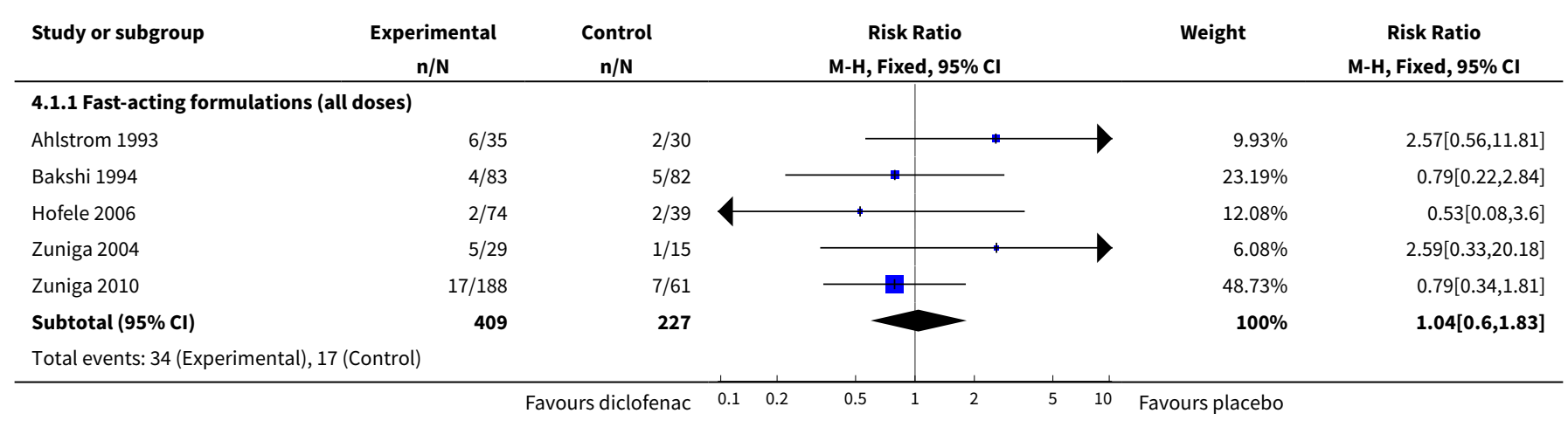




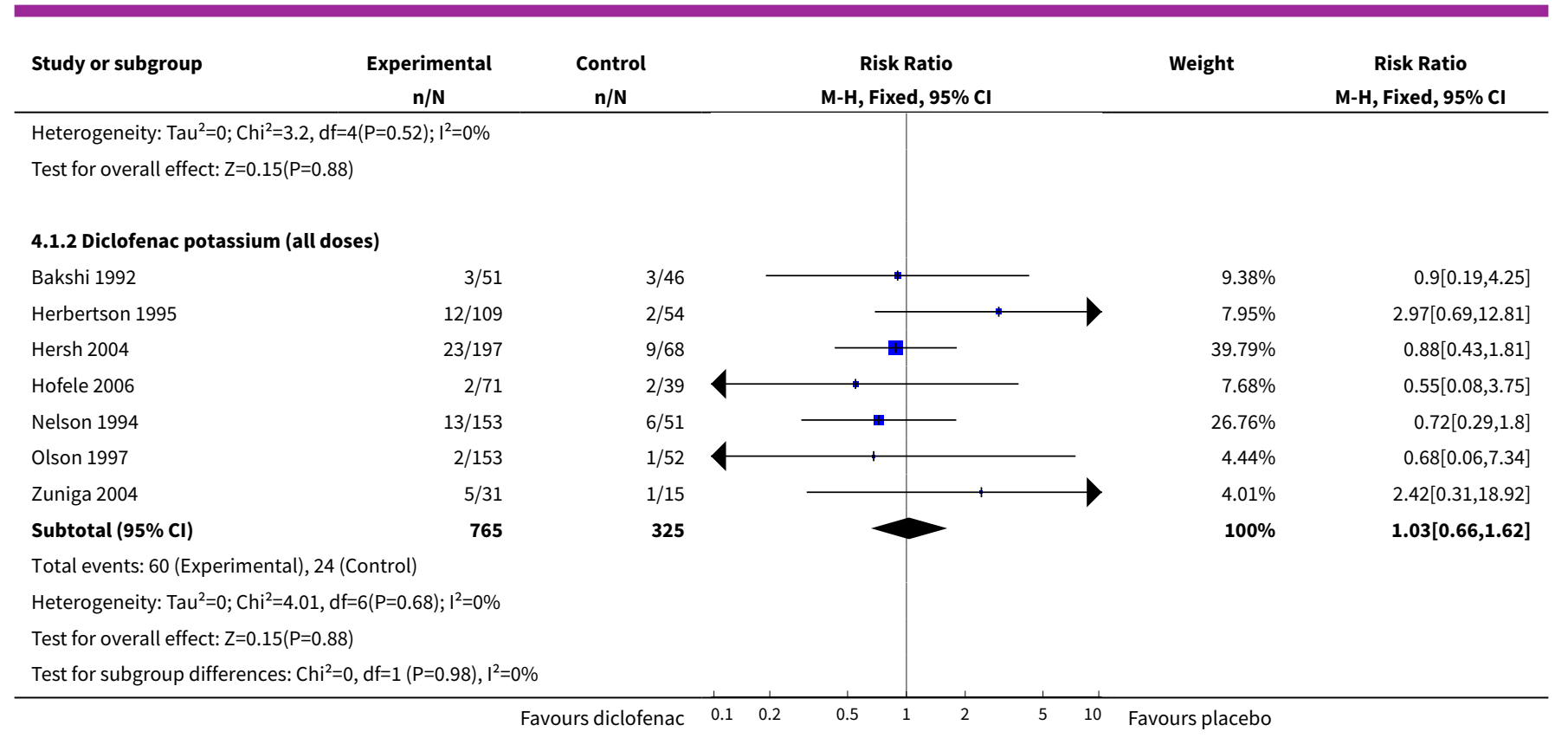

\section{APPENDICES}

\section{Appendix 1. Search strategy for CENTRAL (via CRSO)}

1. MESH DESCRIPTOR diclofenac EXPLODE ALL TREES (1342)

2. diclofenac:TI,AB,KY (3052)

3. 1 or 2

4. MESH DESCRIPTOR Pain, Postoperative EXPLODE ALL TREES (9177

5. ((postoperative adj4 pain ${ }^{\star}$ ) or (post-operative adj4 pain ${ }^{\star}$ ) or post-operative-pain ${ }^{\star}$ or (post* adj4 pain*) or (postoperative adj4 analgesi*) or (post-operative adj4 analgesi*) or "post-operative analgesi*"):TI,AB,KY (15252)

6. ((post-surgical adj4 pain*) or ("post surgical" adj4 pain*) or (post-surgery adj4 pain*)):TI,AB,KY (99)

7. (("pain-relief after surg*") or ("pain following surg*") or ("pain control after")):TI,AB,KY (309)

8. (("post surg*" or post-surg*) AND (pain* or discomfort)):TI,AB,KY (329)

9. ((pain* adj4 "after surg*") or (pain* adj4 "after operat" ) or (pain* adj4 "follow* operat*") or (pain* adj4 "follow* surg*")):TI,AB,KY (713)

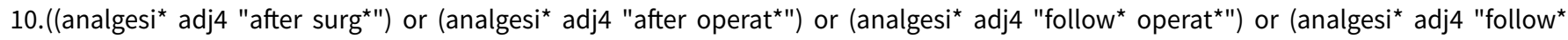
surg*")):TI,AB,KY (285)

11.4 or 5 or 6 or 7 or 8 or 9 or $10(18203)$

12.3 and 11 (895)

13.2008 TO 2015:YR (246363)

14.12 and 13 (354)

\section{Appendix 2. Search strategy for MEDLINE via Ovid}

1. Diclofenac/ (6116)

2. diclofenac.mp. (8832)

3. 1 or $2(8835)$

4. Pain, postoperative/ (28041)

5. exp Surgical Procedures, Operative/ (2440682)

6. ((postoperative adj4 pain $)$ or (post-operative adj4 pain ${ }^{\star}$ ) or post-operative-pain ${ }^{\star}$ or (post* adj4 pain ${ }^{\star}$ ) or (postoperative adj4 analgesi ${ }^{\star}$ ) or (post-operative adj4 analgesi^) or "post-operative analgesi*").mp. (45590)

7. ((post-surgical adj4 pain*) or ("post surgical" adj4 pain*) or (post-surgery adj4 pain*)).mp. (311)

8. ("pain-relief after surg*" or "pain following surg*" or "pain control after").mp. (564)

9. (("post surg*" or post-surg*) and (pain* or discomfort)).mp. (1164)

Single dose oral diclofenac for acute postoperative pain in adults (Review) 
10.((pain* adj4 "after surg*") or (pain* adj4 "after operat*") or (pain* adj4 "follow* operat*") or (pain* adj4 "follow* surg*")).mp. (2617)

11.((analgesi* adj4 "after surg*") or (analgesi* adj4 "after operat*") or (analgesi^ adj4 "follow* operat*") or (analgesi" adj4 "follow* surg*")).mp. (555)

12.4 or 5 or 6 or 7 or 8 or 9 or 10 or 11 (2456902)

13.randomized controlled trial.pt. (386549)

14.controlled clinical trial.pt. (88799)

15.randomized.ab. (284481)

16.placebo.ab. (149366)

17.drug therapy.fs. (1745898)

18.randomly.ab. (201462)

19.trial.ab. (293536)

20.groups.ab. (1288153)

21.13 or 14 or 15 or 16 or 17 or 18 or 19 or 20 (3290048)

22.3 and 12 and 21 (1115)

23.limit 22 to yr="2008 -Current" (324)

For the earlier review the following brand names were also searched:

allvoran; dolotren; nu-diclo; anfenax; ecofenac; olfen; apo-diclo; effekton; panamor; arcanafenac; fenac; pharmaflam; arthrotec; fenaren; polyflam; benfofen; flamrase; primofenac; brovaflamp; flector; rewodina; cataflam; flexagen; rheufenac; clinifam; flogofenac; rheumasan; dedolor; forgenac; rhumalgan; deflamat; fortfen; ribex; delphimix; grofenac; sigafenac; delphinac; inflamac; silino; diclac; isclofen; sodiclo; diclo; jenafenac; toryxil; diclobene; lexobene; tratul; dicloberl; liberalgium; valenac; diclofex; luase; veltex; diclomax; magluphen; voldal; diclomelan; monoflam; vologen; dicloreum; motifene; volraman; diclosyl; myogit; voltaren; diclozip; naclof; voltarene; dignofenac; novapirina; voltarol; dolobasan; novo-difenac; xenid.

\section{Appendix 3. Search strategy for EMBASE (via Ovid)}

1. Diclofenac/ (30696)

2. diclofenac.mp. (31948)

3. 1 or 2 (31948)

4. Pain, postoperative/ (44185)

5. exp Surgical Procedures, Operative/ (3553121)

6. ((postoperative adj4 pain*) or (post-operative adj4 pain*) or post-operative-pain* or (post* adj4 pain*) or (postoperative adj4 analgesi ${ }^{\star}$ ) or (post-operative adj4 analgesi^) or "post-operative analgesi*").mp. (90276)

7. ((post-surgical adj4 pain*) or ("post surgical" adj4 pain*) or (post-surgery adj4 pain*)).mp. (796)

8. ("pain-relief after surg*" or "pain following surg*" or "pain control after").mp. (869)

9. (("post surg*" or post-surg*) and (pain* or discomfort)).mp. (2995)

10.((pain* adj4 "after surg*") or (pain* adj4 "after operat*") or (pain* adj4 "follow* operat*") or (pain* adj4 "follow* surg*")).mp. (4013)

11.((analgesi* adj4 "after surg*") or (analgesi* adj4 "after operat*") or (analgesi* adj4 "follow* operat*") or (analgesi* adj4 "follow* surg*")).mp. (799)

12.4 or 5 or 6 or 7 or 8 or 9 or 10 or 11 (3578345)

13.RANDOMIZED CONTROLLED TRIAL/ (363913)

14.DOUBLE-BLIND PROCEDURE/ (120687)

15.CROSSOVER PROCEDURE/ (41726)

16.random*.ti,ab. (954095)

17.factorial ${ }^{\star}$.ti,ab. (24784)

18. (crossover ${ }^{\star}$ or cross over $^{\star}$ or cross-over $\left.{ }^{\star}\right)$.ti,ab. (74478)

19. placebo*.ti,ab. (214812)

20. (doubl ${ }^{\star}$ adj blind $\left.{ }^{\star}\right)$.ti,ab. (154353)

21.assign ${ }^{\star}$. ti,ab. (256178)

22.allocat ${ }^{\star}$.ti,ab. (90878)

23.13 or 14 or 15 or 16 or 17 or 18 or 19 or 20 or 21 or 22 (1367881)

24.3 and 12 and 23 (2021)

25.limit 24 to yr="2008 -Current" (943)

For the earlier review the following brand names were also searched: 
allvoran; dolotren; nu-diclo; anfenax; ecofenac; olfen; apo-diclo; effekton; panamor; arcanafenac; fenac; pharmaflam; arthrotec; fenaren; polyflam; benfofen; flamrase; primofenac; brovaflamp; flector; rewodina; cataflam; flexagen; rheufenac; clinifam; flogofenac; rheumasan; dedolor; forgenac; rhumalgan; deflamat; fortfen; ribex; delphimix; grofenac; sigafenac; delphinac; inflamac; silino; diclac; isclofen; sodiclo; diclo; jenafenac; toryxil; diclobene; lexobene; tratul; dicloberl; liberalgium; valenac; diclofex; luase; veltex; diclomax; magluphen; voldal; diclomelan; monoflam; vologen; dicloreum; motifene; volraman; diclosyl; myogit; voltaren; diclozip; naclof; voltarene; dignofenac; novapirina; voltarol; dolobasan; novo-difenac; xenid.

\section{Appendix 4. Glossary}

\section{Categorical rating scale:}

The most common is the five-category scale (none, slight, moderate, good or lots, and complete). For analysis numbers are given to the verbal categories (for pain intensity, none $=0$, mild $=1$, moderate $=2$, and severe $=3$, and for relief, none $=0$, slight $=1$, moderate $=2$, good or lots $=3$, and complete $=4$ ). Data from different subjects are then combined to produce means (rarely medians) and measures of dispersion (usually standard errors of means). The validity of converting categories into numerical scores was checked by comparison with concurrent visual analogue scale measurements. Good correlation was found, especially between pain relief scales using cross-modality matching techniques. Results are usually reported as continuous data, mean, or median pain relief or intensity. Few studies present results as discrete data, giving the number of participants who report a certain level of pain intensity or relief at any given assessment point. The main advantages of the categorical scales are that they are quick and simple. The small number of descriptors may force the scorer to choose a particular category when none describes the pain satisfactorily.

\section{Visual analogue scale (VAS):}

Lines with left end labelled "no relief of pain" and right end labelled "complete relief of pain" seem to overcome this limitation imposed by discrete categories. Participants mark the line at the point that corresponds to their pain. The scores are obtained by measuring the distance between the no relief end and the participant's mark, usually in millimetres. The main advantages of VAS are that they are simple and quick to score, avoid imprecise descriptive terms, and provide many points from which to choose. More concentration and co-ordination are needed, which can be difficult postoperatively or with neurological disorders.

\section{Total pain relief (TOTPAR):}

TOTPAR is calculated as the sum of pain relief scores over a period of time. If a participant had complete pain relief immediately after taking an analgesic, and maintained that level of pain relief for 6 hours, they would have a 6 -hour TOTPAR of the maximum of 24 . Differences between pain relief values at the start and end of a measurement period are dealt with by the composite trapezoidal rule. This is a simple method that approximately calculates the definite integral of the area under the pain relief curve by calculating the sum of the areas of several trapezoids that together closely approximate to the area under the curve.

\section{Summed pain intensity difference (SPID):}

SPID is calculated as the sum of the differences between the pain scores over a period of time. Differences between pain intensity values at the start and end of a measurement period are dealt with by the trapezoidal rule.

VAS TOTPAR and VAS SPID are visual analogue versions of TOTPAR and SPID.

See "Measuring pain" in Bandolier's Little Book of Pain, Oxford University Press, Oxford. 2003; pp 7-13 (Moore 2003).

Appendix 5. Results for individual studies: efficacy

\begin{tabular}{|c|c|c|c|c|c|c|}
\hline & & Analgesia & & & Rescue med & :ation \\
\hline Study ID & Treatment & PI or PR & $\begin{array}{l}\text { Number } \\
\text { with } 50 \% \\
\text { PR }\end{array}$ & $\begin{array}{l}\text { PGR: v } \\
\text { good or ex- } \\
\text { cellent }\end{array}$ & $\begin{array}{l}\text { Median } \\
\text { time to use } \\
\text { (hr) }\end{array}$ & $\%$ using \\
\hline $\begin{array}{l}\text { Ahlstrom } \\
1993\end{array}$ & $\begin{array}{l}\text { (1) Diclofenac (soluble) } 50 \mathrm{mg}, \mathrm{n}=35 \\
\text { (2) Ibuprofen (tablets) } 400 \mathrm{mg}, \mathrm{n}=32 \\
\text { (3) Placebo, } \mathrm{n}=30\end{array}$ & $\begin{array}{l}\text { TOTPAR 6: } \\
\text { (1) } 153 \mathrm{~mm} \\
\text { (3) } 292 \mathrm{~mm}\end{array}$ & $\begin{array}{l}\text { (1) } 21 / 35 \\
\text { (3) } 3 / 50\end{array}$ & $\begin{array}{l}\text { at } 6 \text { hours: } \\
\text { (1) } 23 / 35 \\
\text { (3) } 5 / 30\end{array}$ & no data & $\begin{array}{l}\text { at } 6 \text { hours: } \\
\text { (1) } 40 \\
\text { (3) } 77\end{array}$ \\
\hline $\begin{array}{l}\text { Bakshi } \\
1992\end{array}$ & (1) Diclofenac K 50 mg, n = 51 & $\begin{array}{l}\text { TOTPAR 6: } \\
\text { (1) } 10\end{array}$ & $\begin{array}{l}\text { (1) } 35 / 51 \\
\text { (2) } 16 / 54\end{array}$ & $\begin{array}{l}\text { no usable } \\
\text { data }\end{array}$ & $\begin{array}{l}\text { no usable } \\
\text { data }\end{array}$ & $\begin{array}{l}\text { at } 6 \text { hours: } \\
\text { (1) } 33\end{array}$ \\
\hline
\end{tabular}

Single dose oral diclofenac for acute postoperative pain in adults (Review) 
(Continued)
(2) Diclofenac $\mathrm{Na}$ (enteric coated) $50 \mathrm{mg}$,
(2) 7.3
(3) $10 / 46$
(2) 41 $\mathrm{n}=54$
(3) 5.2
(3) 59
(3) Placebo, $n=46$

\begin{tabular}{|c|c|c|c|c|c|c|}
\hline $\begin{array}{l}\text { Bakshi } \\
1994\end{array}$ & $\begin{array}{l}\text { (1) Diclofenac (soluble) } 50 \mathrm{mg}, \mathrm{n}=83 \\
\text { (2) Ibuprofen } 400 \mathrm{mg}, \mathrm{n}=80\end{array}$ & $\begin{array}{l}\text { TOTPAR 6: } \\
\text { (1) } 15.5\end{array}$ & $\begin{array}{l}\text { (1) } 62 / 83 \\
\text { (3) } 31 / 82\end{array}$ & $\begin{array}{l}\text { no usable } \\
\text { data }\end{array}$ & $\begin{array}{l}\text { Mean: } \\
\text { (1) } 5.35\end{array}$ & $\begin{array}{l}\text { at } 6 \text { hours: } \\
\text { (1) } 24\end{array}$ \\
\hline & (3) Placebo, $n=82$ & (3) 8.9 & & & (3) 3.36 & (3) 65 \\
\hline Chang 2002 & $\begin{array}{l}\text { (1) Diclofenac } \mathrm{Na} \text { (enteric coated) } 50 \mathrm{mg} \text {, } \\
\mathrm{n}=121 \\
\text { (2) Rofecoxib } 50 \mathrm{mg}, \mathrm{n}=121 \\
\text { (3) Placebo, } \mathrm{n}=63\end{array}$ & $\begin{array}{l}\text { TOTPAR 6: } \\
\text { (1) } 5.8 \\
\text { (3) } 4.3\end{array}$ & $\begin{array}{l}\text { (1) } 32 / 121 \\
\text { (3) } 8 / 63\end{array}$ & $\begin{array}{l}\text { no usable } \\
\text { data }\end{array}$ & $\begin{array}{l}\text { (1) } 1.62 \\
\text { (3) } 1.62\end{array}$ & $\begin{array}{l}\text { at } 8 \text { hours: } \\
\text { (1) } 67 \\
\text { (3) } 76\end{array}$ \\
\hline
\end{tabular}

\begin{tabular}{llllll}
\hline $\begin{array}{l}\text { Cooper } \\
1996\end{array}$ & (1) Diclofenac Na $50 \mathrm{mg}, \mathrm{n}=18$ & TOTPAR 6: & (1) $10 / 18$ & $\begin{array}{l}\text { no usable } \\
\text { data }\end{array}$ & Mean: \\
& (2) Misoprostol $200 \mu \mathrm{g}, \mathrm{n}=21$ & (1) 12.5 & (4) $0 / 11$ & & (1) 4.68 \\
& (3) Diclofenac $\mathrm{Na}+$ misoprostol 50 & (4) 1.9 & & (4) 2.11 \\
$\mathrm{mg} / 200 \mu \mathrm{g}, \mathrm{n}=20$ & & & \\
& (4) Placebo, $\mathrm{n}=11$ & & \\
\hline
\end{tabular}

\begin{tabular}{|c|c|c|c|c|c|c|}
\hline \multirow{3}{*}{$\begin{array}{l}\text { Desjardins } \\
2004\end{array}$} & (1) Diclofenac Na $100 \mathrm{mg}, \mathrm{n}=85$ & TOTPAR 6: & (1) $13 / 85$ & at 8 hours: & (1) 2.03 & no data \\
\hline & (2) Rofecoxib $50 \mathrm{mg}, \mathrm{n}=85$ & (1) 4.8 & (3) $4 / 82$ & (1) $6 / 85$ & (3) 1.41 & \\
\hline & (3) Placebo, $n=82$ & (3) 2.9 & & (3) $3 / 82$ & & \\
\hline
\end{tabular}

\begin{tabular}{lllllll}
\hline $\begin{array}{l}\text { Herbertson } \\
1995\end{array}$ & (1) Diclofenac K $50 \mathrm{mg}, \mathrm{n}=52$ & TOTPAR 6: & (1) $29 / 52$ & at 8 hours: & (1) 5.6 & at 6 hours: \\
& (2) Diclofenac K $100 \mathrm{mg}, \mathrm{n}=52$ & (1) 12.1 & (2) $29 / 52$ & (1) $28 / 52$ & (2) 6.1 & (1) 50 \\
& (3) Aspirin $650 \mathrm{mg}, \mathrm{n}=53$ & (2) 12.2 & (4) $5 / 52$ & (2) $25 / 52$ & (4) 1.5 & (2) 54 \\
& (4) Placebo, $\mathrm{n}=52$ & (4) 3.7 & & (4) $6 / 52$ & (4) 82 \\
\hline
\end{tabular}

\begin{tabular}{|c|c|c|c|c|c|c|}
\hline \multirow[t]{4}{*}{ Hersh 2004} & $\begin{array}{l}\text { (1) Diclofenac K } 25 \text { mg, n = 63 } \\
\text { (2) Diclofenac K } 50 \text { mg, n = 68 }\end{array}$ & $\begin{array}{l}\text { TOTPAR 6: } \\
\text { (1) } 11.68\end{array}$ & $\begin{array}{l}\text { (1) } 43 / 63 \\
\text { (2) } 44 / 68\end{array}$ & $\begin{array}{l}\text { no usable } \\
\text { data }\end{array}$ & $\begin{array}{l}\text { (1) } 5.83 \\
\text { (2) }>6\end{array}$ & $\begin{array}{l}\text { at } 6 \text { hours: } \\
\text { (1) } 51\end{array}$ \\
\hline & (3) Diclofenac K 100 mg, $n=66$ & (2) 13.86 & (3) $52 / 66$ & & (3) $>6$ & (2) 37 \\
\hline & (4) Placebo, $n=68$ & (3) 16.16 & (4) $11 / 68$ & & (4) 1.67 & (3) 32 \\
\hline & & (4) 4.99 & & & & (4) 79 \\
\hline
\end{tabular}

\begin{tabular}{|c|c|c|c|c|c|c|}
\hline Hofele 2006 & $\begin{array}{l}\text { (1) Diclofenac } K \text { sachet } 50 \text { mg, } n=74 \\
\text { (2) Diclofenac } K \text { tablet } 50 \text { mg, } n=71 \\
\text { (3) Placebo, } n=39\end{array}$ & $\begin{array}{l}\text { TOTPAR 6: } \\
\text { (1) } 15.5 \\
\text { (2) } 14.1 \\
\text { (3) } 7.2\end{array}$ & $\begin{array}{l}\text { (1) } 55 / 74 \\
\text { (2) } 47 / 71 \\
\text { (3) } 11 / 39\end{array}$ & $\begin{array}{l}\text { no usable } \\
\text { data }\end{array}$ & $\begin{array}{l}\text { Ka- } \\
\text { plan-Meier } \\
\text { estimate } \\
\text { Mean: } \\
\text { (1) } 8.7 \\
\text { (2) } 8.9 \\
\text { (3) } 4.5\end{array}$ & $\begin{array}{l}\text { at } 8 \text { hours: } \\
\text { (1) } 37 \\
\text { (2) } 37 \\
\text { (3) } 72\end{array}$ \\
\hline
\end{tabular}

\begin{tabular}{|c|c|c|c|c|c|c|}
\hline $\begin{array}{l}\text { Kubitzek } \\
2003\end{array}$ & (1) Diclofenac K 25 mg, n = 83 & $\begin{array}{l}\text { TOTPAR 6: val- } \\
\text { ues not given }\end{array}$ & (1) $42 / 83$ & at 6 hours: & (1) 3.94 & at 6 hours: \\
\hline
\end{tabular}


(Continued)
(2) Paracetamol $1000 \mathrm{mg}, \mathrm{n}=78$
(3) $7 / 84$
(1) $25 / 83$
(3) 1.47
(1) 77
(3) Placebo, $n=84$
(3) $1 / 84$
(3) 89

\begin{tabular}{|c|c|c|c|}
\hline \multirow[t]{4}{*}{$\begin{array}{l}\text { Manvelian } \\
\text { 2012a }\end{array}$} & $\begin{array}{l}\text { (1) Diclofenac K nanoparticle } 18 \mathrm{mg}, \mathrm{n}= \\
49\end{array}$ & $\begin{array}{l}\text { TOTPAR } 6 \text { (es- } \\
\text { timated): }\end{array}$ & $\begin{array}{l}\text { (1) } 24 / 49 \\
\text { (2) } 25 / 51\end{array}$ \\
\hline & $\begin{array}{l}\text { (2) Diclofenac K nanoparticle } 36 \mathrm{mg}, \mathrm{n}= \\
51\end{array}$ & (1) 11 & (3) $18 / 51$ \\
\hline & (3) Celecoxib 400 mg, $n=51$ & (2) 11 & (4) $3 / 51$ \\
\hline & (4) Placebo, n= 51 & (4) 3 & \\
\hline
\end{tabular}

Mehlisch

(1) Diclofenac K 50 mg, n = 53

TOTPAR 6:

(1) $28 / 53$

no usable

(1) 5.9

at 6 hours:

1995

(2) Diclofenac K 100 mg, $n=52$

(1) 11.6

(2) $35 / 52$

(2) 7.3

(1) 49

(3) Aspirin $650 \mathrm{mg}, \mathrm{n}=51$

(2) 14.3

(4) $4 / 52$

(4) 1.8

(2) 30

(4) Placebo, $n=52$

(4) 3.3

(4) 84

Nelson

(1) Diclofenac K 25 mg, n = 50

TOTPAR 6:

(1) $23 / 50$

no data

(1) 5.3

at 6 hours:

1994

(2) Diclofenac K 50 mg, n = 50

(1) 10.5

(2) $28 / 50$

(2) $>8$

(1) 57

(3) Diclofenac K 100 mg, n = 50

(2) 12.2

(3) $35 / 50$

(3) $>8$

(2) 39

(4) Aspirin $650 \mathrm{mg}, \mathrm{n}=50$

(3) 14.8

(5) $4 / 50$

(5) 2.8

(3) 32

(5) Placebo, $n=50$

(5) 3.6

(5) 65

\begin{tabular}{ll}
\hline Olson 1997 & (1) Diclofenac K $25 \mathrm{mg}, \mathrm{n}=52$ \\
& (2) Diclofenac K $50 \mathrm{mg}, \mathrm{n}=50$ \\
& (3) Diclofenac K $100 \mathrm{mg}, \mathrm{n}=51$ \\
(4) Aspirin $650 \mathrm{mg}, \mathrm{n}=50$ \\
(5) Placebo, $\mathrm{n}=52$
\end{tabular}

TOTPAR 4:

(1) $32 / 52$

no usable

(1) 5.4

at 6 hours:

(1) 8.9

(2) $34 / 50$

(2) 3.0

(1) 4

(2) 9.5

(3) $37 / 51$

(3) 5.4

(2) 2

(3) 10.1

(5) $15 / 52$

(5) 2.3

(3) 0

(5) 4.9

(5) 37

Riff 2009
(1) Diclofenac K softgel $25 \mathrm{mg}, \mathrm{n}=73$

SPID 6:
(1) $21 / 102$
(2) Placebo, $n=59$
(2) $3 / 99$

No data

No data

(1) $19 / 73$

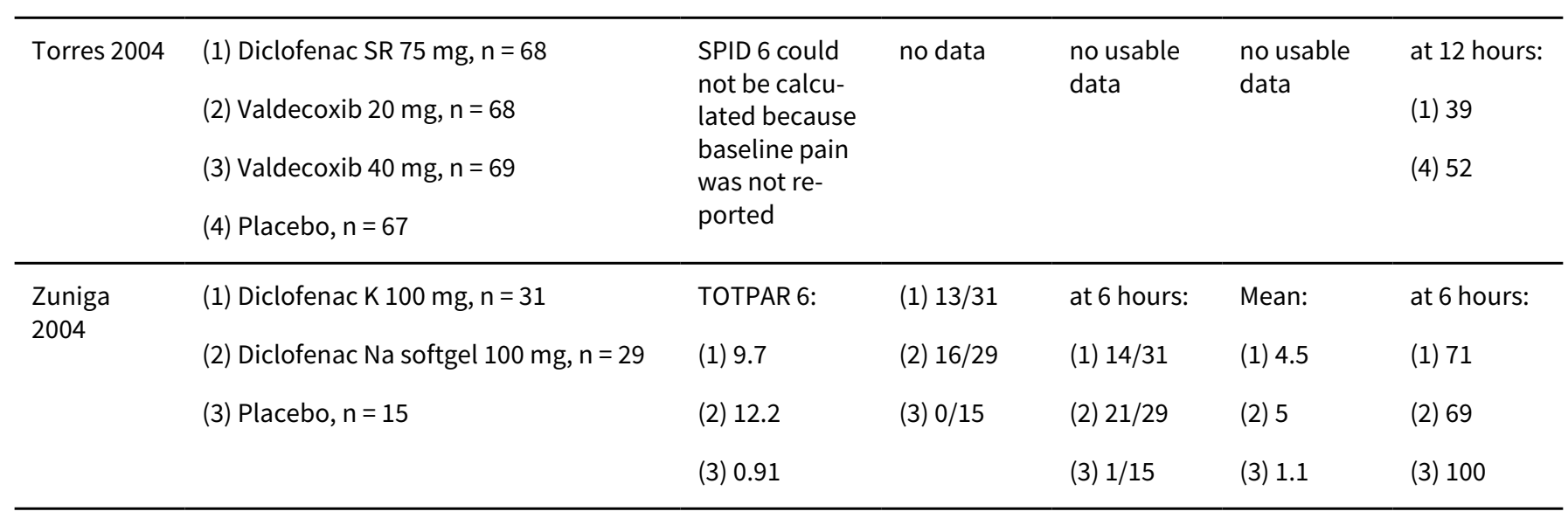


(Continued)

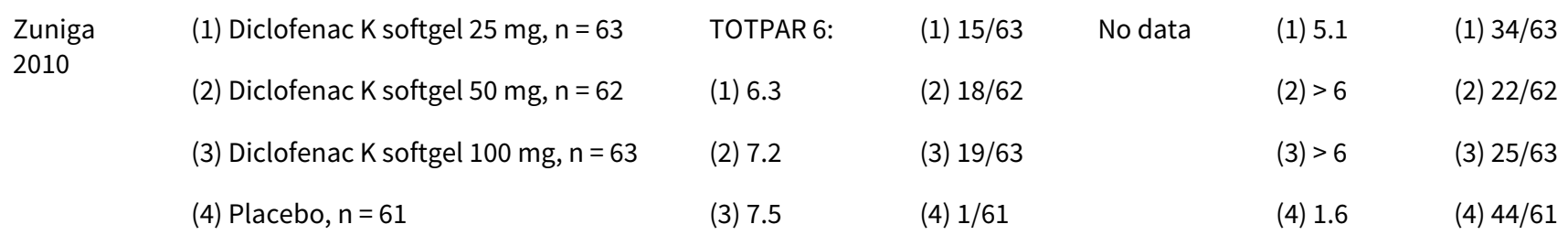

(4) 2.3

K: potassium; Na: sodium; SPID: summed pain intensity difference; SR: slow release; TOTPAR: total pain relief

Appendix 6. Results for individual studies: adverse events

\begin{tabular}{|c|c|c|c|c|c|}
\hline & & Adverse events & & Withdrav & \\
\hline Study ID & Treatment & Any & Serious & $\begin{array}{l}\text { Adverse } \\
\text { event }\end{array}$ & Other \\
\hline Ahlstrom 1993 & $\begin{array}{l}\text { (1) Diclofenac (soluble) } 50 \mathrm{mg}, \mathrm{n}=35 \\
\text { (2) Ibuprofen (tablets) } 400 \mathrm{mg}, \mathrm{n}=32 \\
\text { (3) Placebo, } \mathrm{n}=30\end{array}$ & $\begin{array}{l}\text { At } 6 \text { hours } \\
\text { (1) } 6 / 35 \\
\text { (3) } 2 / 30 \\
\text { considered treat- } \\
\text { ment-related in } 1 \\
\text { diclofenac and } 1 \\
\text { ibuprofen partici- } \\
\text { pant }\end{array}$ & None reported & None & $\begin{array}{l}30 \text { exclusions: } \\
\text { various proto- } \\
\text { col violations }\end{array}$ \\
\hline Bakshi 1992 & $\begin{array}{l}\text { (1) Diclofenac K } 50 \text { mg, n = } 51 \\
\text { (2) Diclofenac Na (enteric coated) } 50 \\
\text { mg, } n=54 \\
\text { (3) Placebo, } n=46\end{array}$ & $\begin{array}{l}\text { Possibly or proba- } \\
\text { bly treatment-relat- } \\
\text { ed at } 6 \text { hours } \\
\text { (1) } 3 / 51 \\
\text { (2) } 1 / 54 \\
\text { (3) } 3 / 46\end{array}$ & None & None & $\begin{array}{l}29 \text { exclusions: } \\
26 \text { did not need } \\
\text { medication, } \\
3 \text { lost to fol- } \\
\text { low-up }\end{array}$ \\
\hline
\end{tabular}

\begin{tabular}{|c|c|c|c|c|c|}
\hline \multirow[t]{2}{*}{ Bakshi 1994} & $\begin{array}{l}\text { (1) Diclofenac (soluble) } 50 \mathrm{mg}, \mathrm{n}=83 \\
\text { (2) Ibuprofen } 400 \mathrm{mg}, \mathrm{n}=80\end{array}$ & $\begin{array}{l}\text { At } 6 \text { hours } \\
\text { (1) } 4 / 83\end{array}$ & None reported & None & $\begin{array}{l}12 \text { exclusions: } \\
\text { various proto- } \\
\text { col violations }\end{array}$ \\
\hline & (3) Placebo, $n=82$ & (3) $5 / 82$ & & & \\
\hline
\end{tabular}

\begin{tabular}{|c|c|c|c|c|c|}
\hline Chang 2002 & $\begin{array}{l}\text { (1) Diclofenac Na (enteric coated) } 50 \\
\text { mg, } n=121 \\
\text { (2) Rofecoxib } 50 \mathrm{mg}, \mathrm{n}=121 \\
\text { (3) Placebo, } \mathrm{n}=63\end{array}$ & No single dose data & $\begin{array}{l}\text { No single dose } \\
\text { data }\end{array}$ & $\begin{array}{l}\text { at } 36 \text { hours: } \\
\text { (3) } 1 / 63 \text { (asth- } \\
\text { ma flare) }\end{array}$ & None \\
\hline
\end{tabular}

\begin{tabular}{llll}
\hline Cooper & (1) Diclofenac Na $50 \mathrm{mg}, \mathrm{n}=18$ & No usable data. \\
1996 & (2) Misoprostol $200 \mu \mathrm{g}, \mathrm{n}=21$ & $\begin{array}{l}\text { All adverse events } \\
\text { were transient and } \\
\text { mild, and consid- }\end{array}$ & \\
& &
\end{tabular}


(Continued)
(3) Diclofenac $\mathrm{Na}+$ misoprostol 50
ered normal se-
$\mathrm{mg} / 200 \mu \mathrm{g}, \mathrm{n}=20$
quale of surgical
(4) Placebo, $n=11$
procedure and
probably unrelated
to study drug

\begin{tabular}{|c|c|c|c|c|}
\hline \multirow{3}{*}{$\begin{array}{l}\text { Desjardins } \\
2004\end{array}$} & (1) Diclofenac Na $100 \mathrm{mg}, \mathrm{n}=85$ & at 24 hours: & None & (1) $1 / 8$ \\
\hline & (2) Rofecoxib $50 \mathrm{mg}, \mathrm{n}=85$ & (1) $38 / 85$ & & (3) $3 /$ \\
\hline & (3) Placebo, $n=82$ & (3) $41 / 82$ & & \\
\hline
\end{tabular}

\begin{tabular}{lll}
\hline $\begin{array}{l}\text { Herbertson } \\
1995\end{array}$ & (1) Diclofenac K $50 \mathrm{mg}, \mathrm{n}=52$ & At 8 hours \\
& (2) Diclofenac K $100 \mathrm{mg}, \mathrm{n}=52$ & (1) $6 / 54$ \\
& (3) Aspirin $650 \mathrm{mg}, \mathrm{n}=53$ & (2) $6 / 55$ \\
(4) Placebo, $\mathrm{n}=52$ & (4) $2 / 54$
\end{tabular}

None 8 in total

In total, 8 participants did not contribute to any efficacy analysis, 23 did not contribute to reported TOTPAR 8

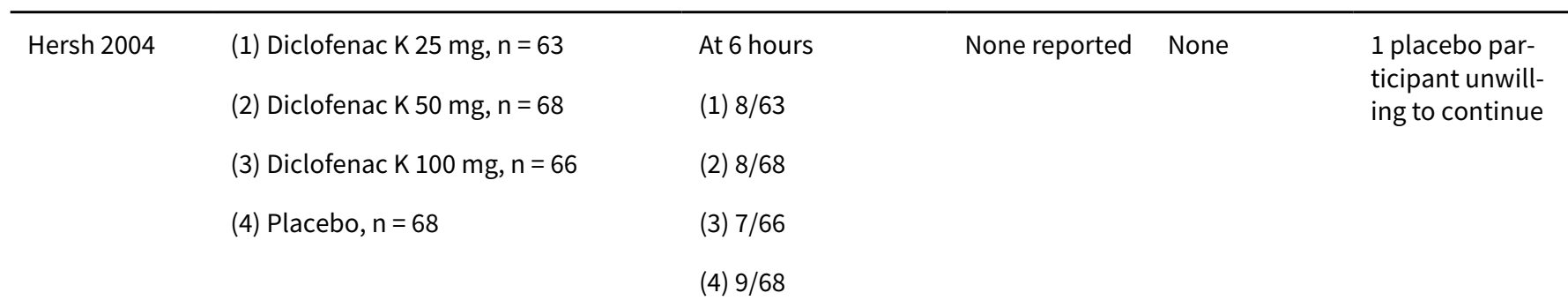

\begin{tabular}{|c|c|c|c|c|c|}
\hline \multirow[t]{2}{*}{ Hofele 2006} & $\begin{array}{l}\text { (1) Diclofenac } K \text { sachet } 50 \mathrm{mg}, \mathrm{n}=74 \\
\text { (2) Diclofenac } \mathrm{K} \text { tablet } 50 \mathrm{mg}, \mathrm{n}=71\end{array}$ & $\begin{array}{l}\text { at } 8 \text { hours: } \\
\text { (1) } 2 / 74\end{array}$ & None & None & $\begin{array}{l}4 \text { exclusions for } \\
\text { protocol viola- } \\
\text { tions: }\end{array}$ \\
\hline & (3) Placebo, $n=39$ & $\begin{array}{l}\text { (2) } 2 / 71 \\
\text { (3) } 2 / 39\end{array}$ & & & $\begin{array}{l}2 \text { diclofenac } \\
\text { sachet, } 1 \text { di- } \\
\text { clofenac tablet, } \\
1 \text { placebo }\end{array}$ \\
\hline
\end{tabular}

\begin{tabular}{|c|c|c|c|c|c|}
\hline Kubitzek 2003 & $\begin{array}{l}\text { (1) Diclofenac K } 25 \text { mg, n = } 83 \\
\text { (2) Paracetamol } 1000 \text { mg, n= } 78 \\
\text { (3) Placebo, } n=84\end{array}$ & $\begin{array}{l}\text { at } 48 \text { hrs: } \\
\text { (1) } 6 / 83 \\
\text { (3) } 2 / 84\end{array}$ & None & None & $\begin{array}{l}1 \text { placebo par- } \\
\text { ticipant exclud- } \\
\text { ed for protocol } \\
\text { violation }\end{array}$ \\
\hline
\end{tabular}

\begin{tabular}{|c|c|c|c|c|c|}
\hline $\begin{array}{l}\text { Manvelian } \\
\text { 2012a }\end{array}$ & $\begin{array}{l}\text { (1) Diclofenac K nanoparticle } 18 \mathrm{mg} \text {, } \\
\mathrm{n}=49 \\
\text { (2) Diclofenac K nanoparticle } 36 \mathrm{mg} \text {, } \\
\mathrm{n}=51\end{array}$ & $\begin{array}{l}\text { Any treat- } \\
\text { ment-emergent ad- } \\
\text { verse event at } 12 \\
\text { hours: }\end{array}$ & None reported & None & None reported \\
\hline
\end{tabular}
$\mathrm{n}=51$
(3) Celecoxib $400 \mathrm{mg}, \mathrm{n}=51$
(1) $27 / 49$
(4) Placebo, $n=51$
(2) $31 / 51$
(3) $32 / 51$
(4) $27 / 51$

\begin{tabular}{lllll}
\hline Mehlisch 1995 & (1) Diclofenac K $50 \mathrm{mg}, \mathrm{n}=53$ & at 7 days: & None & None \\
& (2) Diclofenac K $100 \mathrm{mg}, \mathrm{n}=52$ & (1) $5 / 53$ & \\
\hline
\end{tabular}


(Continued)
(3) Aspirin 650 mg, $n=51$
(2) $8 / 52$
(4) Placebo, $n=52$
(4) $4 / 52$

\begin{tabular}{|c|c|c|c|c|c|}
\hline Nelson 1994 & $\begin{array}{l}\text { (1) Diclofenac K } 25 \text { mg, n = } 50 \\
\text { (2) Diclofenac K } 50 \text { mg, n = } 50 \\
\text { (3) Diclofenac K } 100 \text { mg, n= } 50 \\
\text { (4) Aspirin } 650 \text { mg, n= } 50 \\
\text { (5) Placebo, n = 50 }\end{array}$ & $\begin{array}{l}\text { at } 8 \text { hours: } \\
\text { (1) } 5 / 51 \\
\text { (2) } 4 / 51 \\
\text { (3) } 4 / 51 \\
\text { (5) } 6 / 51\end{array}$ & None reported & None & $\begin{array}{l}1 \text { participant } \\
\text { excluded from } \\
\text { safety analy- } \\
\text { sis, } 3 \text { excluded } \\
\text { from any effica- } \\
\text { cy analysis, } 7 \\
\text { excluded from } \\
\text { 8-hour efficacy } \\
\text { analysis }\end{array}$ \\
\hline Olson 1997 & $\begin{array}{l}\text { (1) Diclofenac K } 25 \text { mg, n = } 52 \\
\text { (2) Diclofenac K } 50 \text { mg, n= } 50 \\
\text { (3) Diclofenac K } 100 \text { mg, n= } 51 \\
\text { (4) Aspirin } 650 \text { mg, n = 50 } \\
\text { (5) Placebo, n = 52 }\end{array}$ & $\begin{array}{l}\text { at } 8 \text { hours: } \\
\text { (1) } 1 / 52 \\
\text { (2) } 0 / 50 \\
\text { (3) } 1 / 51 \\
\text { (5) } 1 / 52\end{array}$ & None & None & None \\
\hline
\end{tabular}

$\begin{array}{ll}\text { Riff } 2009 & \text { (1) Diclofenac K softgel } 25 \mathrm{mg}, \mathrm{n}=102 \text { No single dose data } \\ & \text { (2) Placebo, } \mathrm{n}=99\end{array}$

\begin{tabular}{|c|c|c|c|c|c|}
\hline Torres 2004 & $\begin{array}{l}\text { (1) Diclofenac SR } 75 \text { mg, } n=68 \\
\text { (2) Valdecoxib } 20 \mathrm{mg}, \mathrm{n}=68 \\
\text { (3) Valdecoxib } 40 \mathrm{mg}, \mathrm{n}=69 \\
\text { (4) Placebo, } n=67\end{array}$ & $\begin{array}{l}\text { at } 12 \text { hours: } \\
\text { (1) } 14 / 65 \\
\text { (4) } 17 / 67\end{array}$ & None reported & $\begin{array}{l}\text { No usable da- } \\
\text { ta }\end{array}$ & No usable data \\
\hline $\begin{array}{l}\text { Zuniga } \\
2004\end{array}$ & $\begin{array}{l}\text { (1) Diclofenac K } 100 \mathrm{mg}, \mathrm{n}=31 \\
\text { (2) Diclofenac Na softgel } 100 \mathrm{mg}, \mathrm{n}= \\
29 \\
\text { (3) Placebo, } \mathrm{n}=15\end{array}$ & $\begin{array}{l}\text { at } 24 \text { hours: } \\
\text { (1) } 5 / 31 \\
\text { (2) } 5 / 29 \\
\text { (3) } 1 / 15 \\
\text { most occurred after } \\
\text { rescue medication }\end{array}$ & None & None & $\begin{array}{l}1 \text { participant } \\
\text { excluded due to } \\
\text { protocol viola- } \\
\text { tion }\end{array}$ \\
\hline Zuniga 2010 & $\begin{array}{l}\text { (1) Diclofenac K softgel } 25 \mathrm{mg}, \mathrm{n}=63 \\
\text { (2) Diclofenac K softgel } 50 \mathrm{mg}, \mathrm{n}=62 \\
\text { (3) Diclofenac K softgel } 100 \mathrm{mg}, \mathrm{n}=63 \\
\text { (4) Placebo, } \mathrm{n}=61\end{array}$ & $\begin{array}{l}\text { at } 6 \text { hours: } \\
\text { (1) } 7 / 63 \\
\text { (2) } 5 / 62 \\
\text { (3) } 5 / 63 \\
\text { (4) } 7 / 61\end{array}$ & None & None & None reported \\
\hline
\end{tabular}

K: potassium; Na: sodium; SR: slow release

\section{WHAT'S NEW}




\begin{tabular}{lll}
\hline Date & Event & Description \\
\hline 29 May 2019 & Amended & Contact details updated. \\
\hline 11 October 2017 & Review declared as stable & No new studies likely to change the conclusions are expected. \\
\hline
\end{tabular}

\section{HISTORY}

Protocol first published: Issue 2, 2004

Review first published: Issue 2, 2004

\begin{tabular}{lll}
\hline Date & Event & Description \\
\hline 8 July 2015 & Review declared as stable & This review will be assessed for updating in 2018. \\
\hline 10 March 2015 & $\begin{array}{l}\text { New citation required and conclusions } \\
\text { have changed }\end{array}$ & $\begin{array}{l}\text { Change in emphasis to take into account new insights into drug } \\
\text { formulation. Results have changed, with significantly improved } \\
\text { efficacy found for diclofenac potassium over previous versions of } \\
\text { this review }\end{array}$ \\
\hline
\end{tabular}

9 March $2015 \quad$ New search has been performed

New searches. Three new studies (652 participants) added, with $26 \%$ increase in number of participants in diclofenac versus placebo comparisons. 'Risk of bias' and 'Summary of findings' tables added

\section{September $2011 \quad$ Review declared as stable}

\begin{tabular}{lll}
\hline 8 February 2011 & Amended & Contact details updated. \\
\hline 24 September 2010 & Amended & Contact details updated. \\
\hline
\end{tabular}

23 December 2008 New citation required and conclusions
have changed
Eight new studies (1206 participants in comparisons of diclofenac and placebo) were added in December 2008 (Chang 2002a; Cooper 1996; Desjardins 2004a; Hersh 2004; Hofele 2006; Kubitzek 2003; Torres 2004; Zuniga 2004). Overall the NNT for at least $50 \%$ pain relief over 4 to 6 hours was not changed, but the potassium salt was significantly better than the sodium salt.

New studies added, analyses updated, additional data on use of rescue medication, and new authors.

\begin{tabular}{lll}
\hline 26 September 2008 New search has been performed & $\begin{array}{l}\text { New studies added, analyses updated, additional data on use of } \\
\text { rescue medication, and new authors. }\end{array}$
\end{tabular}

22 May $2008 \quad$ Amended Converted to new review format.

\section{CONTRIBUTIONS OFAUTHORS}

For the earliest review: JB and JE were involved with searching, quality scoring, data extraction, analysis, and writing. RAM and HM were involved with planning, quality scoring, analysis, and writing.

For the previous update: PD and SD were involved with searching, data extraction, quality scoring, analysis and writing. RAM was involved in analysis and writing. HM acted as arbitrator and was involved in writing.

For this version of the review, RAM and SD were involved with searching, data extraction, quality scoring, analysis and writing. PW acted as arbitrator and was involved in writing. 
SD will be responsible for updating.

\section{DECLARATIONS OF INTEREST}

SD has no conflicts relating to this review or any similar product.

PW has no conflicts relating to this review or any similar product.

RAM has no conflicts relating to this review or any similar product.

For transparency, SD, PW, and RAM have received research support from charities, government, and industry sources at various times, but none relate to this review. SD, PW, and RAM are funded by the NIHR for work on a series of reviews informing the unmet need of chronic pain and providing the evidence for treatments of pain.

\section{SOURCES OF SUPPORT}

\section{Internal sources}

- Oxford Pain Relief Trust, UK.

General institutional support

\section{External sources}

- No sources of support supplied

\section{DIFFERENCES BETWEEN PROTOCOL AND REVIEW}

There was no protocol for this review. The major difference between this review and previous versions was the addition of 'Risk of bias' and 'Summary of findings' tables, and a concentration on formulation of diclofenac in the analysis.

\section{INDEX TERMS}

\section{Medical Subject Headings (MeSH)}

Acute Pain [ ${ }^{*}$ drug therapy]; Administration, Oral; Anti-Inflammatory Agents, Non-Steroidal [*administration \& dosage] [adverse effects] [chemistry]; Chemistry, Pharmaceutical; Cyclooxygenase Inhibitors [administration \& dosage] [adverse effects] [chemistry]; Diclofenac [*administration \& dosage] [adverse effects] [chemistry]; Pain, Postoperative [ ${ }^{\star}$ drug therapy]; Randomized Controlled Trials as Topic

\section{MeSH check words}

Adult; Humans 